\title{
INEL Operable Unit 7-13 Retrieval/Ex Situ Thermal Treatment Configuration Options INEL Buried Waste Integrated Demonstration Systems Analysis Project \\ EGG-WTD-10204
}

Prepared by:

EGG-WID--10204

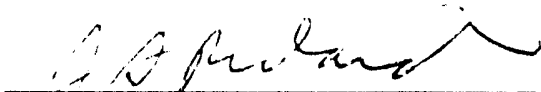

DE93 001938

V. G. Richardson

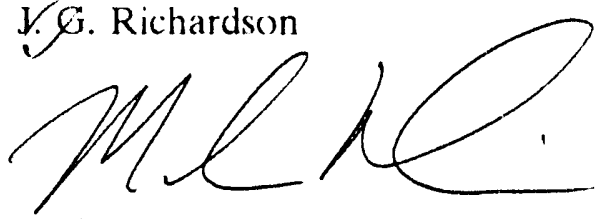

M. J. Rudin

$7 / 31 / 92$

Date

$\because i,-i 25$

M. C. O'Bricn

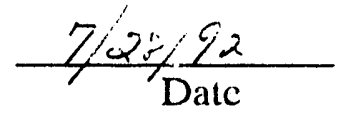

$\frac{1 / h_{\text {fumw }}}{\text { J. L. Morrison }}$

$\frac{2+d i c 52}{\text { Datc }}$

13 has

B. Raivo

$\frac{7-3 /-92}{\text { Date }}$

Reviewed by:
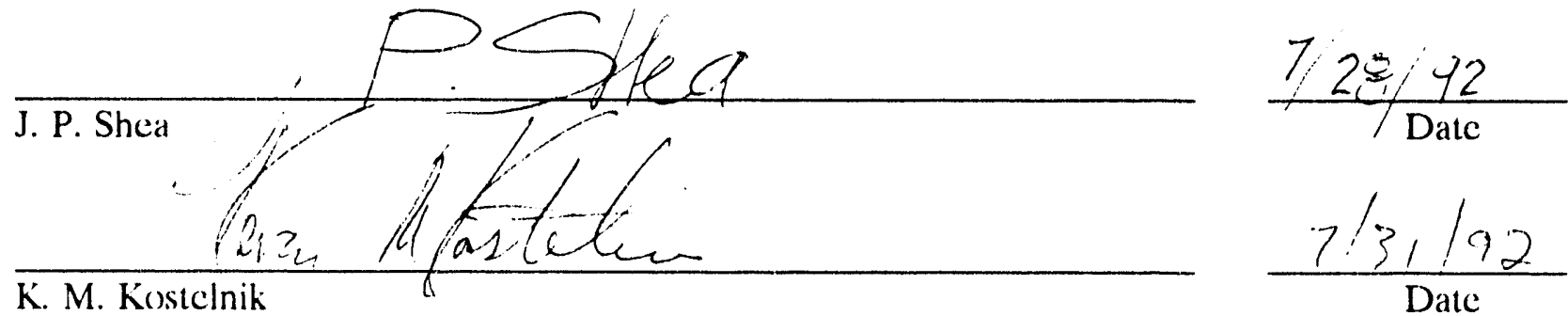

Approved by:

S. K. Merrill

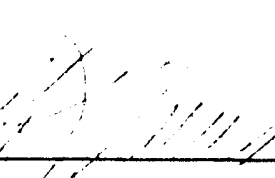

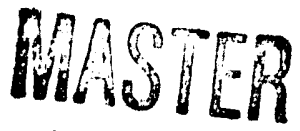

$8 / 3 / 92$

Date 


\title{
INEL Operable Unit 7-13 Retrieval/Ex Situ Thermal Treatment Configuration Options INEL Buried Waste Integrated Demonstration Systems Analysis Project
}

\author{
J. G. Richardson \\ M. J. Rudin \\ M. C. O'Brien \\ J. L. Morrison \\ B. Raivo
}

Published July 1992

Idaho National Engineering Laboratory

EG\&G Idaho, Inc. Idaho Falls, Idaho 83415

\author{
Prepared for the \\ U.S. Department of Energy \\ Office of Environmental Restoration and Waste Marragement \\ Under DOE Idaho Field Office \\ Contract DE-AC07-76ID01570
}




\section{ABSTRACT}

Six retrieval/ex situ thermal treatment configuration options have been developed and are presented as end-to-end system block diagrams. Functional subelements are separately discussed and background technical information, assumptions, input, high-level subelement requirements, and output are presented for each option. 


\section{SUMMARY}

The mission of the Buried Waste Integrated Demonstration (BWID) Systems Analysis project is to identify and evaluate cradle-to-grave systems for the remediation of Transuranic (TRU)Contaminated Waste Pits and Trenches within the Subsurface Disposal Area (SDA) of the Radioactive Waste Management Complex (RWMC) at the Idaho National Engineering Laboratory (INEL). The BWID program will use the results of the BWID Systems Analy s in conjunction with identified Department of Energy (DOE) Complex buried waste needs to develop a long-term strategy for improving buried waste remediation capabilities throughout the DOE system.

An earlier report identified and pre-screened a number of possible options for the remediation of wastes buried at the INEL SDA per criteria set forth in DOE Order 47(1).1, Project Management Systems. The report recommended the following three configuration options for future cvaluation: Retrieval/Ex Situ Thermal Treatment, Retrieval/Ex Situ Chemical Oxidation and Solidification, and In Situ Vitrification/Retrieval. The current focus of the BWID Systems Analysis is to perform a rigorous evaluation of Retricval/Ex Situ Thermal Treatment configuration options for the remediation of INEL Operable Unit 7-13. The Retrieval/Ex Situ Chemical Oxidation and Solidification, and the In Situ Vitrification/Retrieval configuration options may be studicd further at a later date.

This report presents Buried Waste Retrieval/Ex Situ Thermal Treatment configuration option concepts in the form of block diagrams. Associated with each subelement are high-level input, output, and functional requirements. These configuration options are:
A. Retrieval/Melter Treatment
B. Retricval/Metal Sort/Thermal Treatment
C. Retrieval/No Sort/Incineration/Melter Treatment
D. Retricval/Interim Storage/Melter Treatment
E. Retricval/Interim Storage/Mctal Sort/Thermal Treatment
F. Retrieval/Interim Storage/No Sort/Incineration/Melter Treatment

Each option is presented as a complete end-to-end system, and is summarized in a separate section of this report.

There is a degree of commonality among the six options listed above. The retrieval subelements through waste conveyance and the posttreatment subelements beginning with posttrcatment radioactive assay are identical for all six options. The three thermal treatment options are presented twice, both with and without interim storage between retrieval and treatment. Assumptions and requirements presented in this document will be revised per changes in INEL Environmental Restoration/Waste Management planning assumptions for the remediation of OU 7-13. 


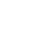




\section{CONTENTS}

ABSTRACT $\ldots \ldots \ldots \ldots \ldots \ldots \ldots \ldots \ldots \ldots \ldots \ldots \ldots \ldots \ldots \ldots \ldots \ldots \ldots \ldots \ldots \ldots i i$

SUMMARY $\ldots \ldots \ldots \ldots \ldots \ldots \ldots \ldots \ldots \ldots \ldots \ldots \ldots \ldots \ldots \ldots \ldots$

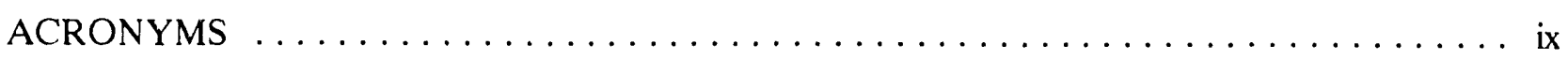

INTRODUCTION $\ldots \ldots \ldots \ldots \ldots \ldots \ldots \ldots \ldots \ldots \ldots \ldots \ldots \ldots \ldots \ldots \ldots \ldots$

Background $\ldots \ldots \ldots \ldots \ldots \ldots \ldots \ldots \ldots \ldots \ldots \ldots \ldots \ldots \ldots \ldots \ldots \ldots \ldots$

Configuration Options Overview $\ldots \ldots \ldots \ldots \ldots \ldots \ldots \ldots \ldots \ldots \ldots \ldots \ldots \ldots \ldots$

A. Retrieval/Melter Treatment . . . . . . . . . . . . . . .

B. Retrieval/Metals Sort/Thermal Treatment $\ldots \ldots \ldots \ldots \ldots \ldots \ldots \ldots$

C. Retrieval/Incineration/Mclter Treatment ............... 4

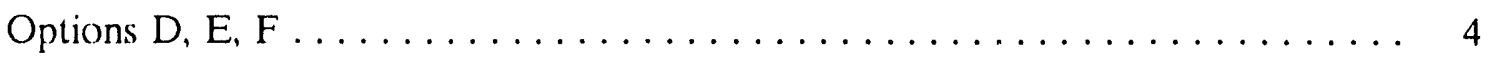

Configuration Option Functional Subelement Discussions $\ldots \ldots \ldots \ldots \ldots \ldots$

Option A-Retrieval/Melter Treatment $\ldots \ldots \ldots \ldots \ldots \ldots \ldots \ldots \ldots \ldots \ldots \ldots$

Option B-Retrieval/Metals Sort/Thermal Treatment . . . . . . . . . . . . . 49

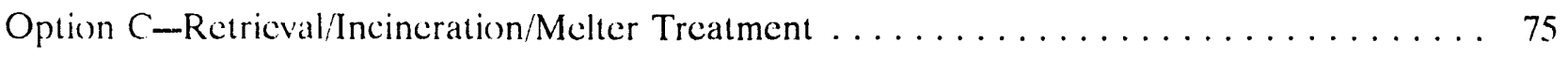

Option D-Retricval/Intcrim Storage/Melter Treatment $\ldots \ldots \ldots \ldots \ldots \ldots \ldots \ldots \ldots$

Option E-Retrieval/Interim Storage/Metals Sort/Thermal Treatment . . . . . . . . . . . . 129

Option F-Retricval/Interim Storage/Incincration/Melter Treatment . . . . . . . . . . 159

REFERENCES ............................... 189

Appendix A-INEL OU 7-13 Waste Pit and Trench Characteristics Tables .......... A-1

\section{FIGURES}

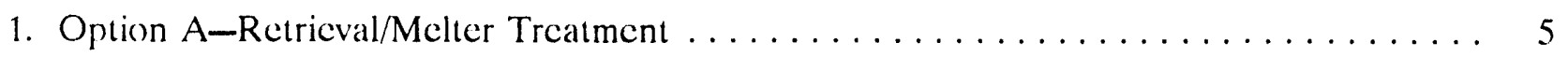

2. Option B-Retricval/Mctals Sort/Thermal Treatment ................ 7

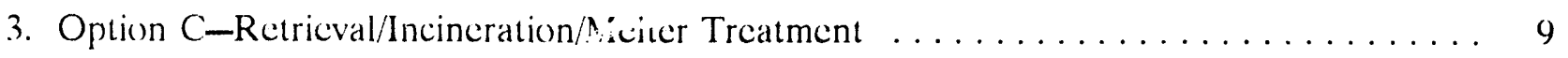


4. Option D-Retrieval/Interim Storage/Melter Treatment $\ldots \ldots \ldots \ldots \ldots \ldots \ldots \ldots \ldots$

5. Option E-Retrieval/Interim Storage/Metals Sort/Thermal Treatment . . . . . . . . 15

6. Option F-Retrieval/Interim Storage/Incineration/Melter Treatment $\ldots \ldots \ldots \ldots \ldots$

7. Original volume of waste pit or trench $\ldots \ldots \ldots \ldots \ldots \ldots \ldots \ldots \ldots \ldots \ldots$

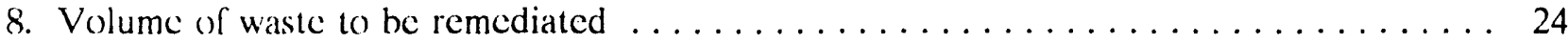




\section{ACRONYMS}

$\begin{array}{ll}\text { ARAR } & \text { applicable or relevant and appropriate requirement } \\ \text { BSG } & \text { borosilicate glass } \\ \text { BWID } & \text { Buried Waste Integrated Demonstration } \\ \text { CERLLA } & \text { Comprehensive Environmental Response, Compensation, and Liability Act } \\ \text { DOE } & \text { U.S. Department of Energy } \\ \text { EPA } & \text { Environmental Protection Agency } \\ \text { ER } & \text { Environmental Restoration } \\ \text { F\&OR } & \text { functional and operational requirement } \\ \text { HEPA } & \text { high efficiency particulate air (filter) } \\ \text { HLW } & \text { high-level waste } \\ \text { HVPM } & \text { High Vapor Pressure Metal } \\ \text { IEB } & \text { iron-enriched basalt } \\ \text { INEL } & \text { Idaho National Engineering Laboratory } \\ \text { LLW } & \text { low-level waste } \\ \text { OU } & \text { Operable Unit } \\ \text { RWMC } & \text { Radioactive Waste Management Complex } \\ \text { SDA } & \text { Subsurface Disposal Area } \\ \text { TRU } & \text { transuranic } \\ \text { UBC } & \text { Uniform Building Code } \\ \text { VOC } & \text { volatile organic cornpound } \\ \text { WAC } & \text { Waste Acceptance Criteria } \\ & \end{array}$




\section{INEL Operable Unit 7-13 Retrieval/Ex Situ Thermal Treatment Configuration Options INEL Buried Waste Integrated Demonstration Systems Analysis Project}

\section{INTRODUCTION}

This report presents Buried Waste Retrieval/Ex Situ Thermal Treatment configuration option concepts and discusses input, output, and high-level requirements for each of their major functional subelements. A configuration option is defined in the Buried Waste Integrated Demonstration (BWID) Systems Analysis project as a top-level block diagram of a cradle-to-grave remedial option whose overall performance is specified by system requirements. In-depth investigation of Retrieval/Ex Situ Thermal Treatment configuration options is not meant to champion these options nor is it meant to preclude other configuration options which may meet system requirements. Addicional configuration options may be considered within the BWID Program at a later date. Every effort has been made during this investigation to remain unbiased.

\section{Background}

The mission of the BWID Systems Analysis project is to identify and evaluate cradle-to-grave systems for the remediation of Transuranic (TRU)-Contaminated Waste Pits and Trenches within the Subsurface Disposal Area (SDA) of the Radioactive Waste Management Complex (RWMC) at the Idaho National Engineering Laboratory (INEL). There are three distinct objectives of the project:

- Direct U.S. Department of Energy (DOE) resources to develop technically sound and cost-effective systems for the complete remediation of DOE buried waste sites

- Guide the selection and technical justification for the development and demonstration of technologies within the BWID Program

- Identify system technology gaps and define quantitative performance requirements for technologies associated with the remediation of DOE Complex buried wastes.

The BWID program will use the results of the BWID Systems Analysis in conjunction with identified DOE Complex buried waste needs to develop a long-term strategy for improving buried waste remediation capabilities throughout the DOE system.

Prior to identifying configuration options for cradle-to-grave remediation of TRU-Contaminated Waste Pits and Trenches (designated as Operable Unit 7-13), system requirements must be identified. System requirements are defined as a set of top-level constraints which direct the realization of an overall process. System requirements will be used for identification and selection of viable remedial options from a population of candidate options. The overall performance of a remediation option is restricted by requirements such as waste/site chisracteristics; applicable or relevant and appropriate requirements (ARARs); and programmatic requirements delined by the Environmental Protection Agency (EPA), DOE, and the State of Idaho. System requirements are not the same as functional and operational requirements (F\&ORs) associated with each of the steps within a particular option. F\&ORs are described as a set of functions and operations that will meet system requirements. 
Proposed system requirements, published in an earlier report, ${ }^{1}$ have been generated from a combination of technical and regulatory sources and are divided into three categories, (a) Programmatic Requirements, (b) Input Requirements, and (c) Output Requirements:

- Programmatic Requirements

- Federal Facility Agreement and Consent Order (U.S. Environmental Protection Agency, U.S. Department of Energy, and State of Idaho) ${ }^{2}$

- $\quad$ Buried Waste Integrated Demonstration Plan ${ }^{3}$

- INEL Environmental Restoration (ER) planning and development assumptions presented in a predecisional draft INEL Environmental Restoration roadmap document $^{\mathrm{a}}$

- INEL Waste Management Operations planning and development assumptions presented in a predecisional draft INEL Waste Management Operations roadmap document $^{\mathrm{b}}$

- Input Requirements

- Historical and technical characterizations of the INEL Subsurface Disposal Area ${ }^{4,5}$

- Output Requirements

- INEL RWMC Low-Level Waste Acceptance Criteria ${ }^{6}$

- INEL TRU Waste Acceptance Criteria ${ }^{7}$

- INEL RWMC Pad A ARARs ${ }^{c}$

An earlier report ${ }^{8}$ identified and pre-screened a number of possible options for the remediation of wastes buried at the INEL SDA per criteria set forth in DOE Order 4700.1, Project Management System.s. The report recommended the following three configuration options for future evaluation: Retrieval/Ex Situ Thermal Treatment, Retrieval/Ex Situ Chemical Oxidation and Solidification, and In Situ Vitrification/Retrieval. The current focus of the BWID Systems Analysis is to perform a rigorous evaluation of Retrieval/Ex Situ Thermal Treatment configuration options for the remediation of INEL Operable Unit 7-13. The Retrieval/Ex Situ Chemical Oxidation and Solidification, and the In Situ Vitrification/Retrieval configuration options may be studied further at a later date.

a. Unpublished report of EG\&G Idaho, Inc., Idaho National Engineering Laboratory, Idaho Falls, Idaho, December 1991.

b. Unpublished report of EG\&G Idaho, Inc., Idaho National Enginecring Laboratory, Idaho Falls, Idaho, September 1991.

c. Transmittal of the Revised Pad A Technical Memorandum on the Preliminary Identification of Combined Federal and State Applicable or Relevant and Appropriate Requirements (ARARs), Letter from S. G. Stiger (INEL Environmental Restoration) to W. N. Sato (DOE-ID), SGS-515. 91. December 5, 1991. 
Each block within a configuration option performs a function and, therefore, is referred to as a "functional subelement." High-level input, output, and lunctional requirements are defined for each functional subclement of the Retricval/Ex Situ Thermal Treatment configuration options. The requirements will direct the insertion of specific technologies into each functional subelement resulting in the formulation of technology process options (systems). A technology process option is a Comprehensive Environmental Response, Compensation, and Liability Act (CERCLA) term used to describe a configuration option that has specific technologies or requirements defined for all functional subelements. The terms "system" and "technology process option" are used synonymously in the BWID Systems Analysis project.

The BWID Performance-Based Technology Selection Filter (PBTSF) is a tool developed within the scope of the BWID Systems Analysis that represents a formal methodology for selecting and rating candidate remediation technology process options. The PBTSF uses two components during its application. One component screens candidate systems against system requirements. The second component involves exccuting trade-off studies that rate technology process options against performance measures derived from CERCLA selection criteria. This approach allows dircet comparison between and among various systems and their enabling technologies.

\section{Configuration Options Overview}

The following six Retrieval/Ex Situ Thermal Treatment configuration options discussed in this report are presented in Figures 1-6:
A. Retrieval/Melter Treatment
B. Retricval/Metals Sort/Thermal Treatment
C. Retricval/Incincration/Melter Treatment
D. Retrieval/Interim Storage/Melter Treatment
E. Retricval/Interim Storage/Metals Sort/Thermal Treatment
F. Retrieval/Interim Storage/Incineration/Melter Treatment.

The configuration options were developed from a variety of experts and reports $8,9,10$ in the sitc/waste characterization, retrieval, waste processing, and thermal treatment area.

\section{A. Retrieval/Melter Treatment}

Once the pits and trenshes are characterized and their contents exhumed, the waste debris/soil is packaged and transported to a treatment facility located adjacent to retrieval operations. Treatment will involve size reduction and eventual full waste stream feed into a high-temperature thermal treatment. Final waste forms will be assayed and designated as low-level waste (LLW) or TRU waste. LLW will be disposed of at the INEL RWMC. TRU waste will be packaged to meet INEL TRU Waste Acceptance Criteria and transported to an INEL Interim Storage lacility until a permanent repository for treated buried waste is opened. 


\section{B. Retrieval/Metals Sort/Thermal Treatment}

Once the pits and trenches are characterized and their contents exhumed, the waste debris/soil is packaged and transported to a treatment facility located adjacent to retricval operations. Treatment will involve size reduction and metal sort. The remaining non-metallic waste streams will be incinerated and recombined with the sorted metals prior to a final high-temperature thermal treatment. Final waste forms will be assayed and designated as LLW or TRU waste. LLW will be disposed of at the INEL RWMC. TRU waste packaged will be to mect INEL TRU Waste Acceptance Criteria and transported to an INEL Interim Storage facility until a permanent repository for treated buried waste is opened.

\section{Retrieval/Incineration/Melter Treatment}

Waste pits and trenches are characterized and their contents exhumed. The waste debris/soil is packaged and transpoited to a treatment facility located adjacent to retrieval operations. Treatment will involve size reduction and full waste stream feed into an incincrator with cventual high-temperature thermal treatment. Final waste forms will be assayed and designated as LLW or TRU. LLW will be disposed of at the INEL RWMC. TRU waste will be packaged to meet INEL TRU Wastc Acceptance Criteria and transported to an INEL Interim Storage facility until a permanent repository for treated buricd waste is opened.

\section{Options D, E, F}

These options are the same as options A, B, and C, respectively, except after retrieval the waste stream will be size reduced, assayed, and packaged for interim storage at the INEL. When a treatment facility is operational, the packaged waste will be withdrawn from interim storage and truated. (Notc: Current INEL ER assumptions ${ }^{\mathrm{d}}$ state that wastes exhumed from waste pits and trenches in OU 7-13 will be placed in interim storage until a suitable treatment facility is operational.)

Figure 7 illustrates a cross-section of a typical OU $7-13$ waste pit or trench. The defined waste seam will be established by an institutional review of the estimated boundaries (sec Figure 8). Establishment of the defined waste seam will be performed by institutional entities. This group will be expected to identify the defined waste seam boundary for each pit or trench that includes some margin in addition to the estimated boundary values.

\section{Configuration Option Functional Subelement Discussions}

High-level requirements, including input and output requirements, are defined in this section for cach functional subelement in Configuration Options $A$ through $F$. Assumptions and requirements presented in this document will be revised per changes in INEL Environmental Restoration/Waste Management planning assupmtions for the remediation of OU 7-13.

d. Unpublished report, "INEL Environmental Restoration Standard Planning Assumptions Document," May 1992. 


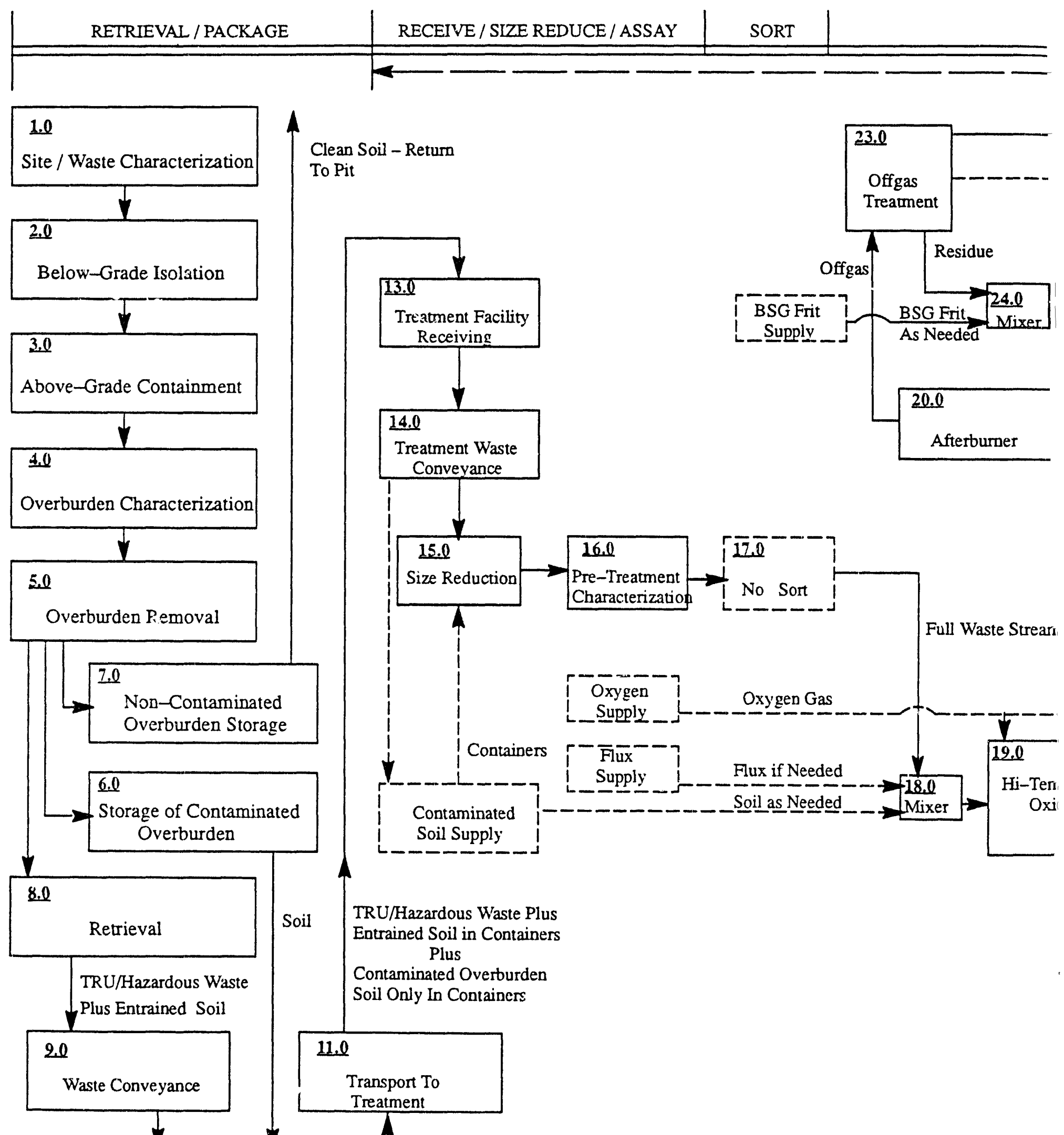

Figure 1. Option A-Retrieval/Melter Treatment. 


\section{reatment}

REATMENT

Thermal Processing Technologies

$\overline{23} \bar{A} \cdot \overline{0}$

$\left[\begin{array}{c}\frac{23 A}{2} \cdot \overline{0} \\ \text { Zero Emissions Offgas } \\ \text { Treatment }\end{array}\right.$

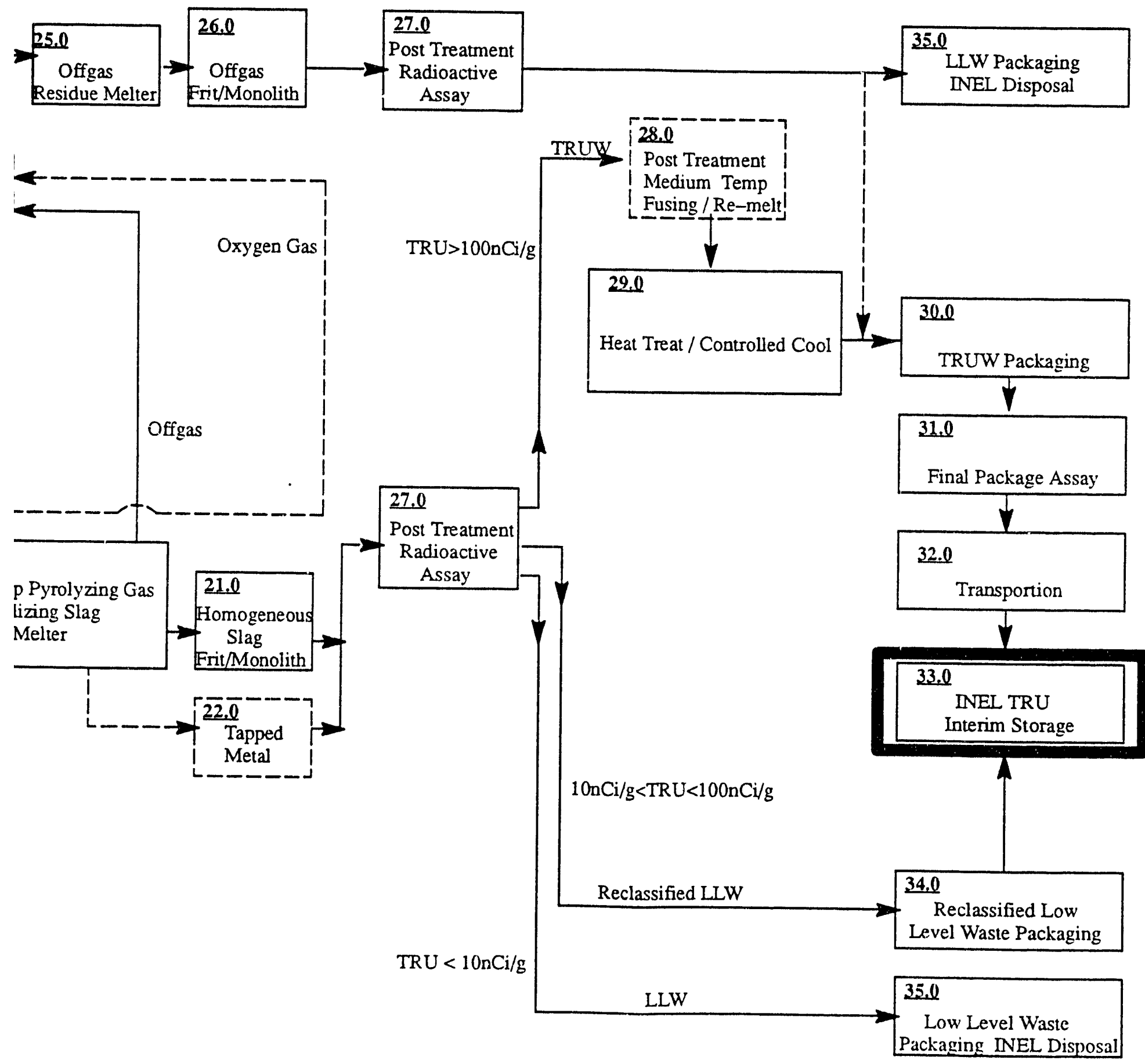




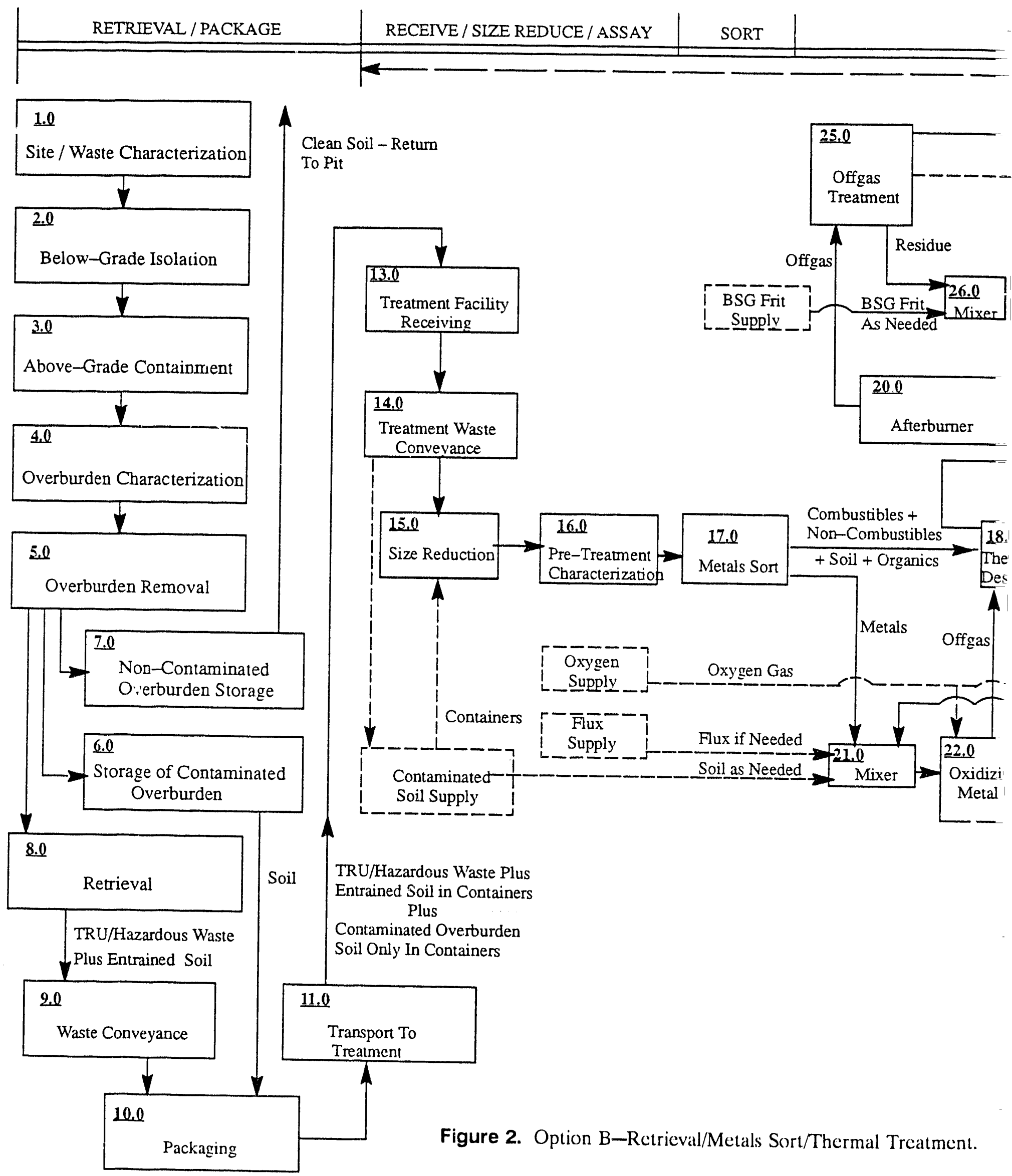




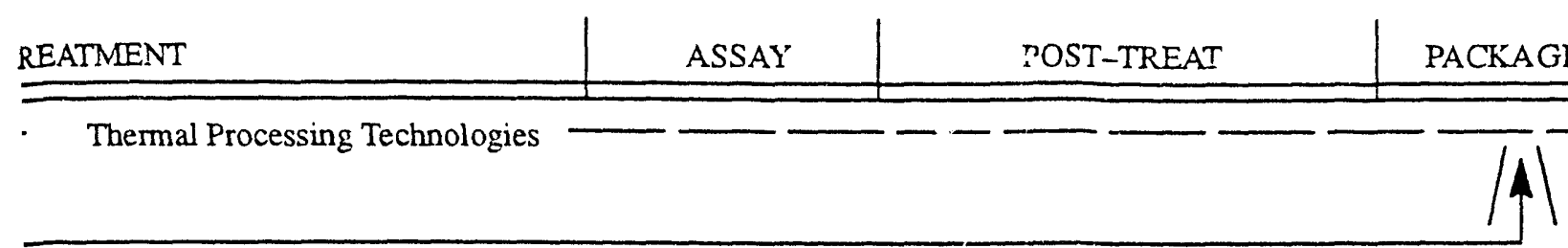

Zero Emissions Offgas

Allowable Stack

Emissions Per

Permits

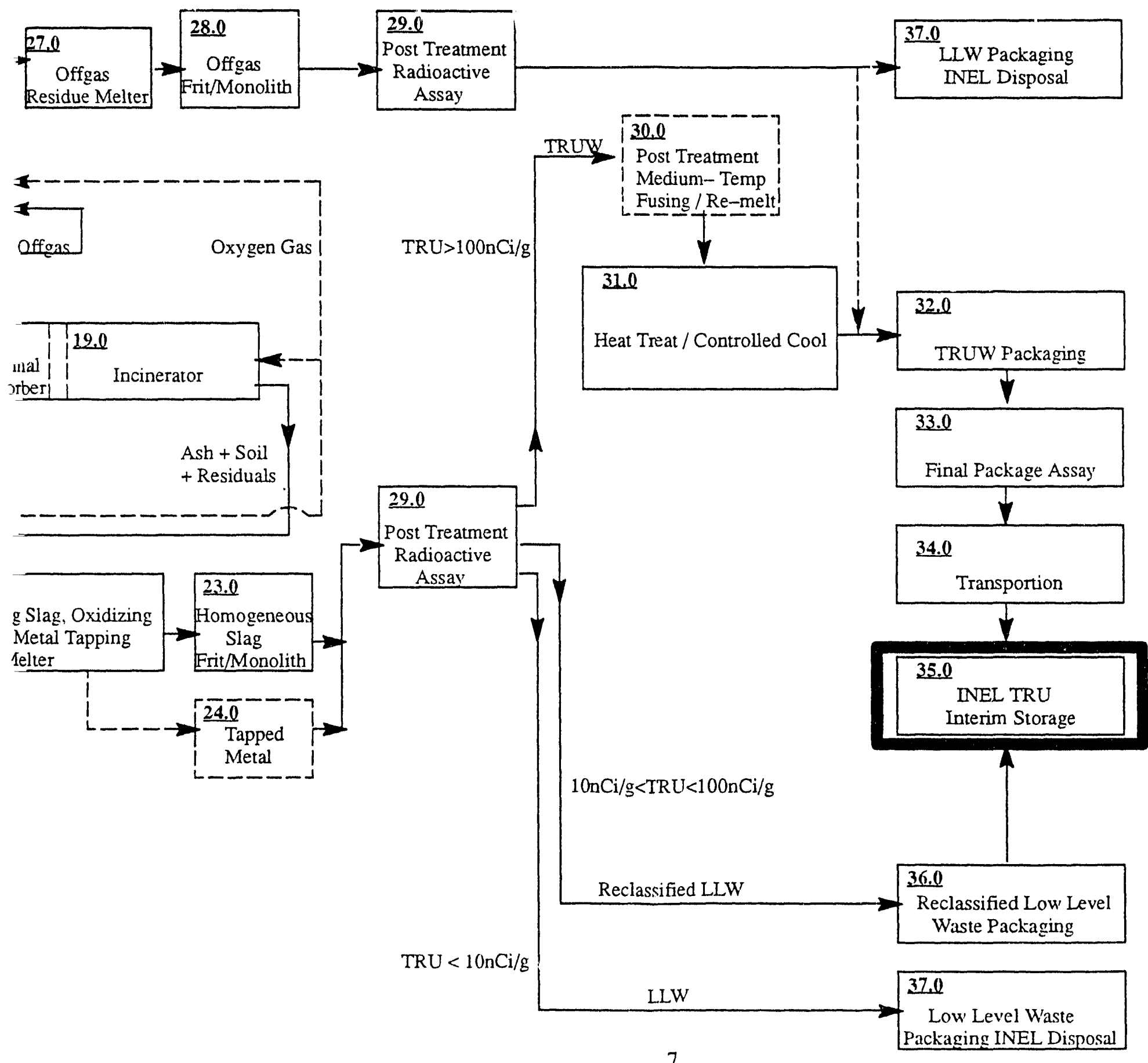



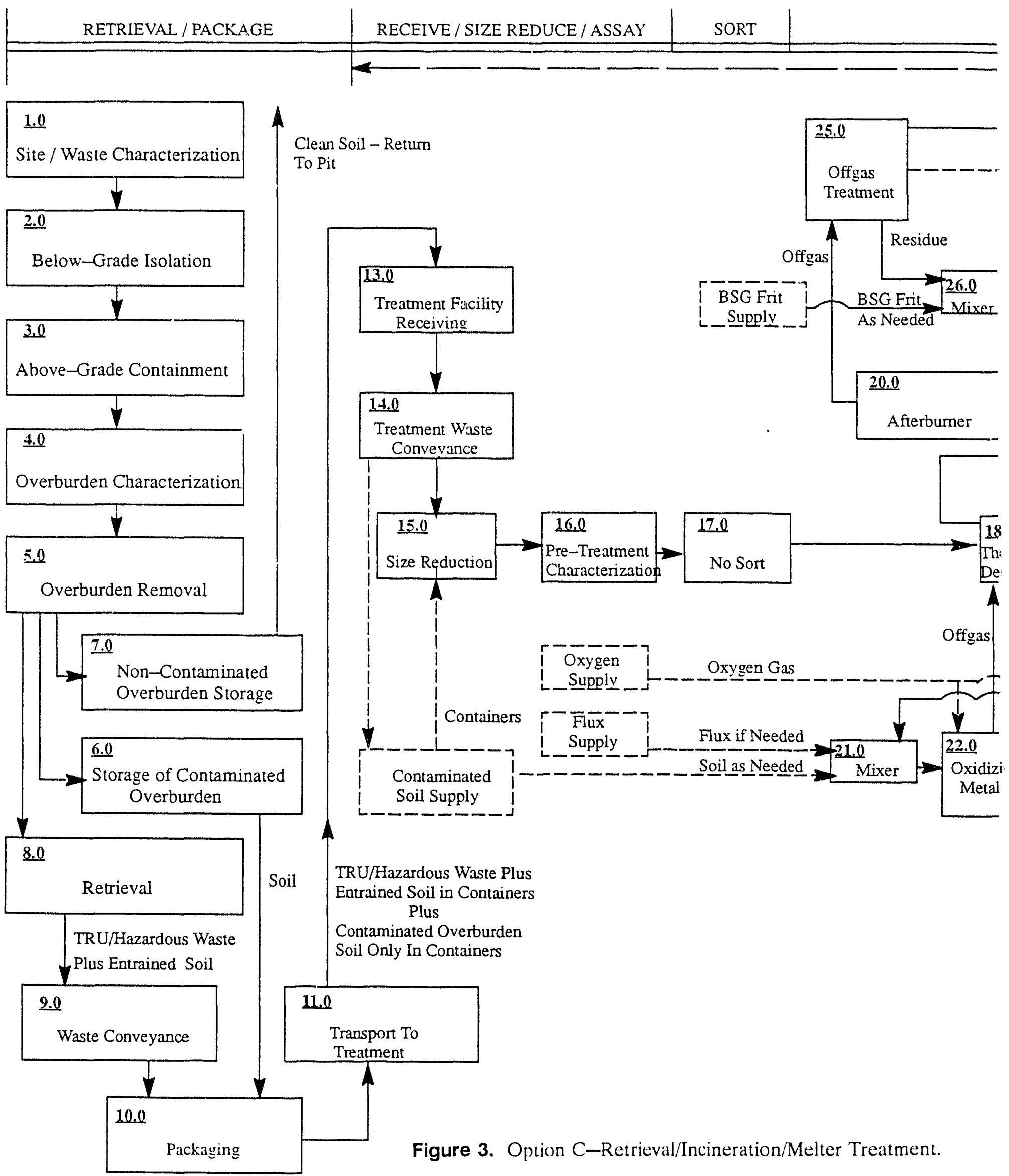


$\left[\begin{array}{c}\frac{25 \mathrm{~A} \cdot 0}{\text { Zero Emissions Offgas }} \\ \text { Treatment }\end{array}\right]$

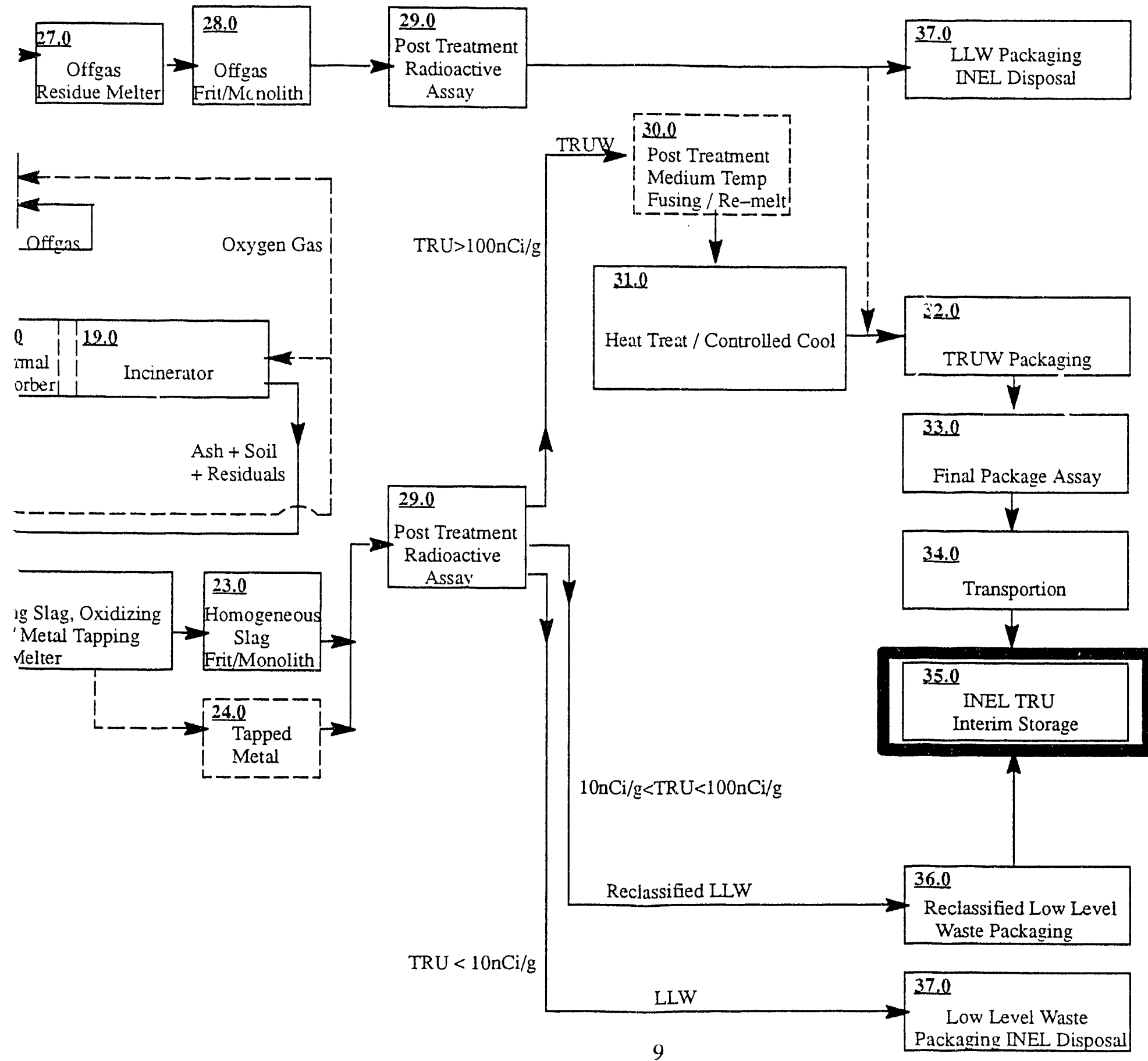




\section{0}

Site / Waste Characterization
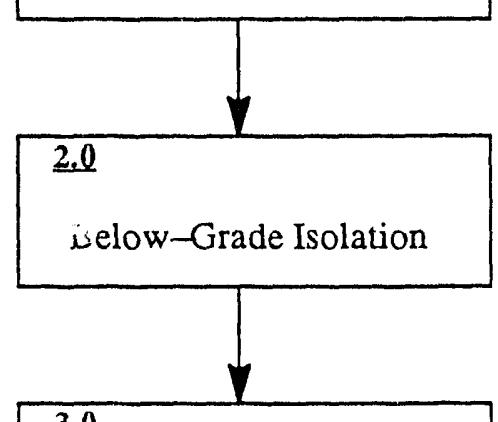

$\underline{3.0}$

Above-Grade Containment

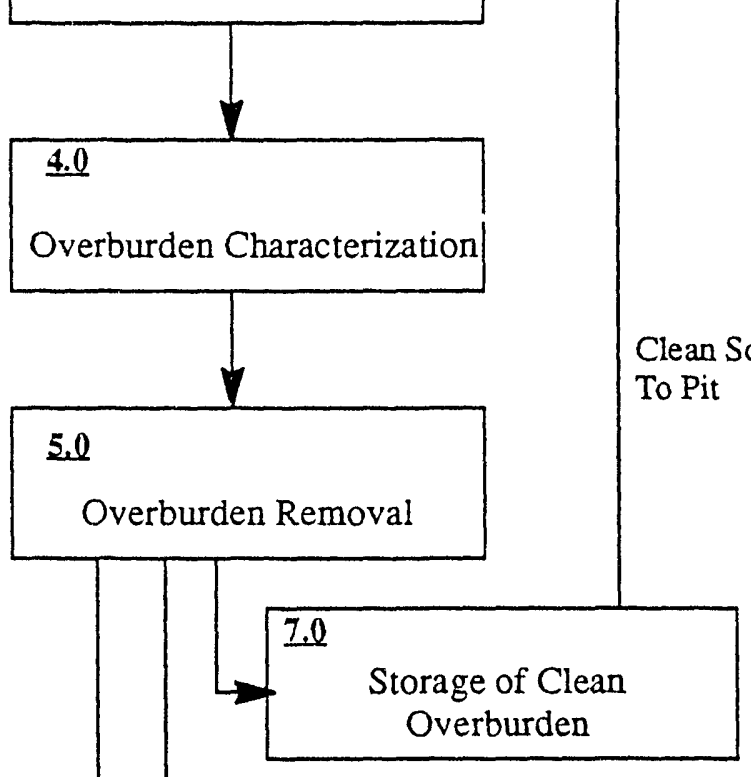

Clean Soil - Return

To Pit
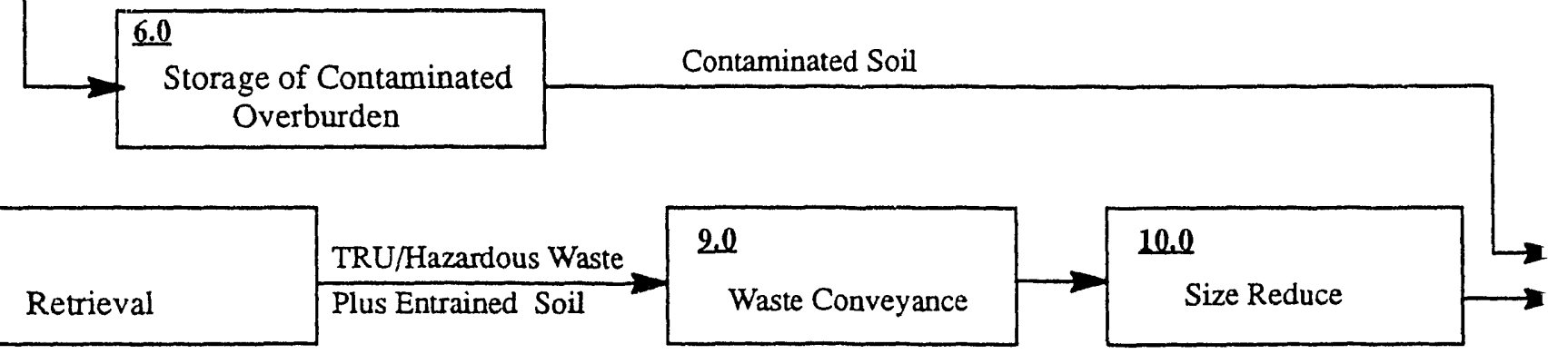

Figure 4. Option D-Retrieval/Interim Storage/Melter Treatment. 
Interim Storage / Melter Treatment

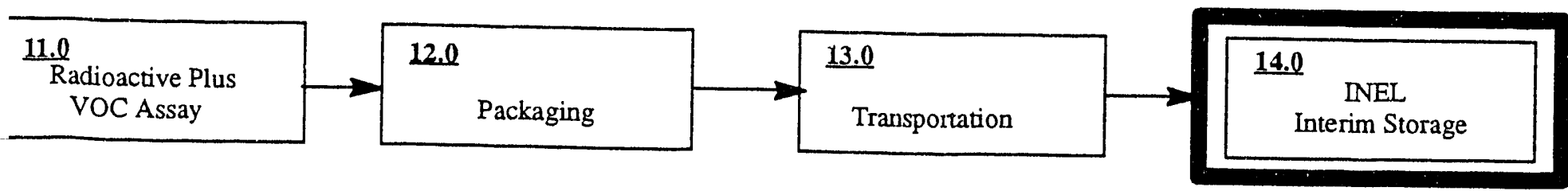




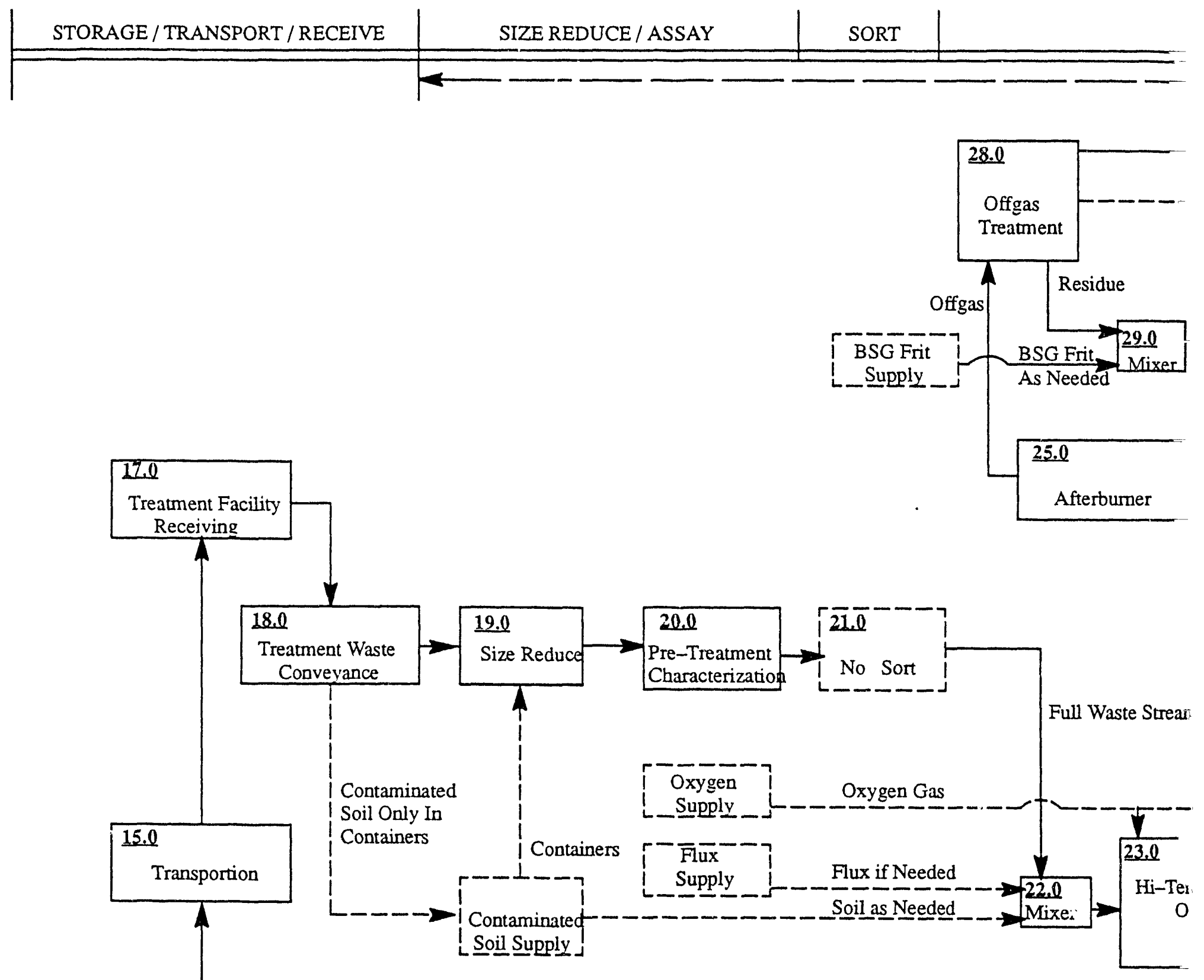

TRU / Hazardous Waste Plus All

Entrained Soil in Containers

Or

Contaminated Soil From Removed

Underburden In Containers

\subsection{INEL \\ Interim Storage}

Figure 4. (continued). 

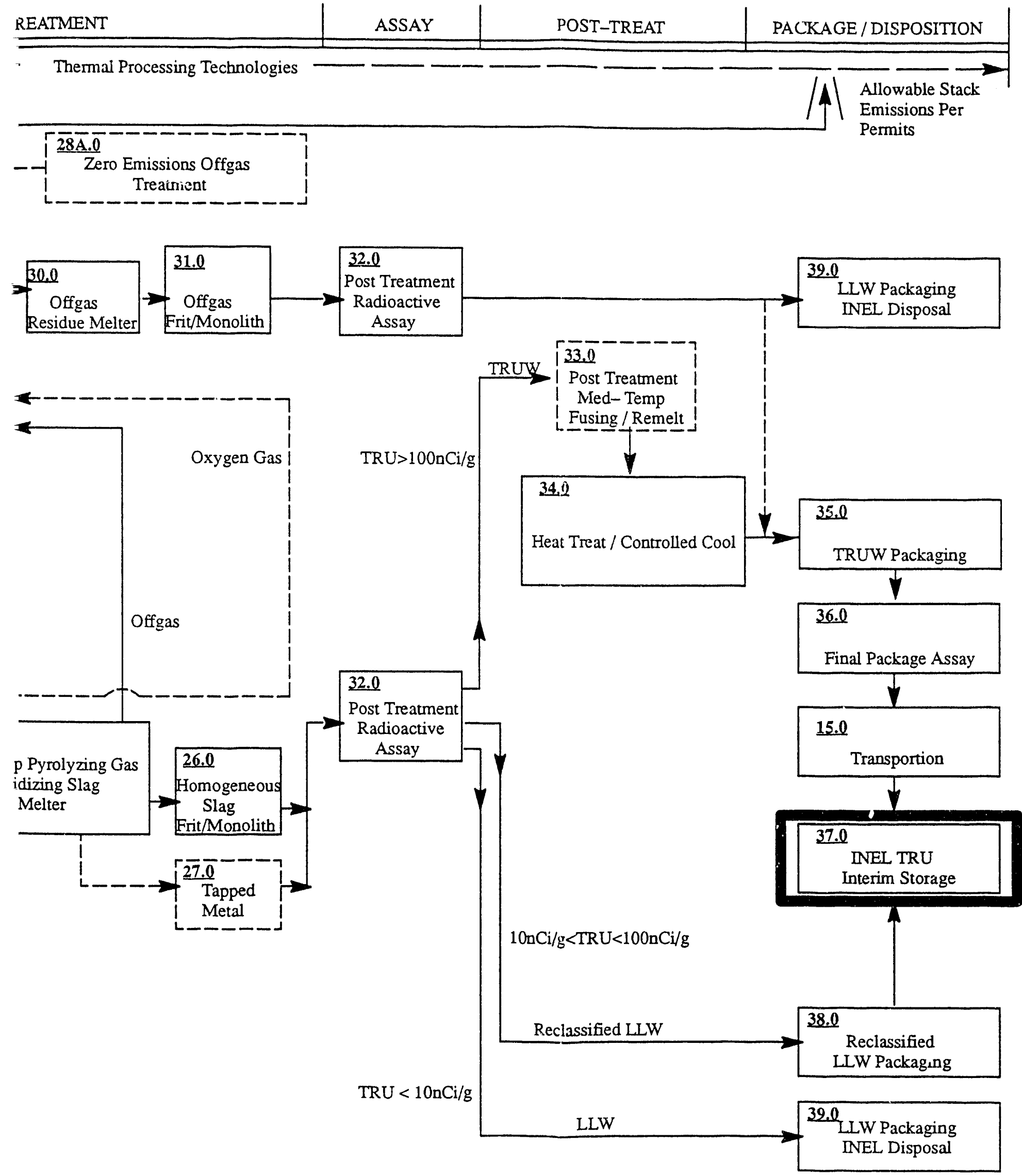


\section{RETRIEVAL}

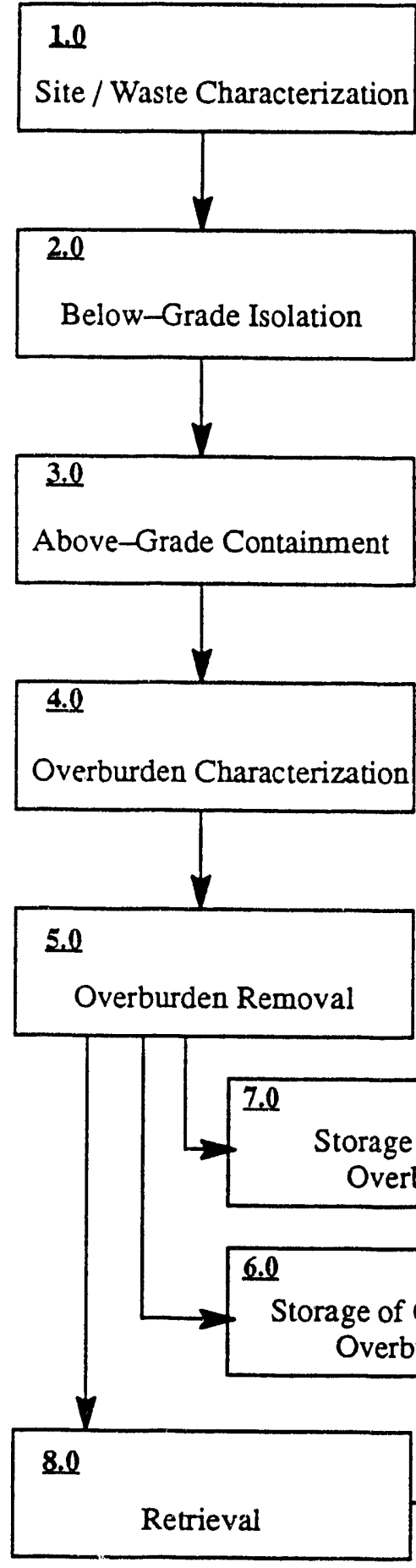

Clean Soil - Return

To Pit

Figure 5. Option E-Retrieval/Interim Storage/Metals Sort/Thermal Treatment. 


\section{Ietals Sort / Thermal Treatment}




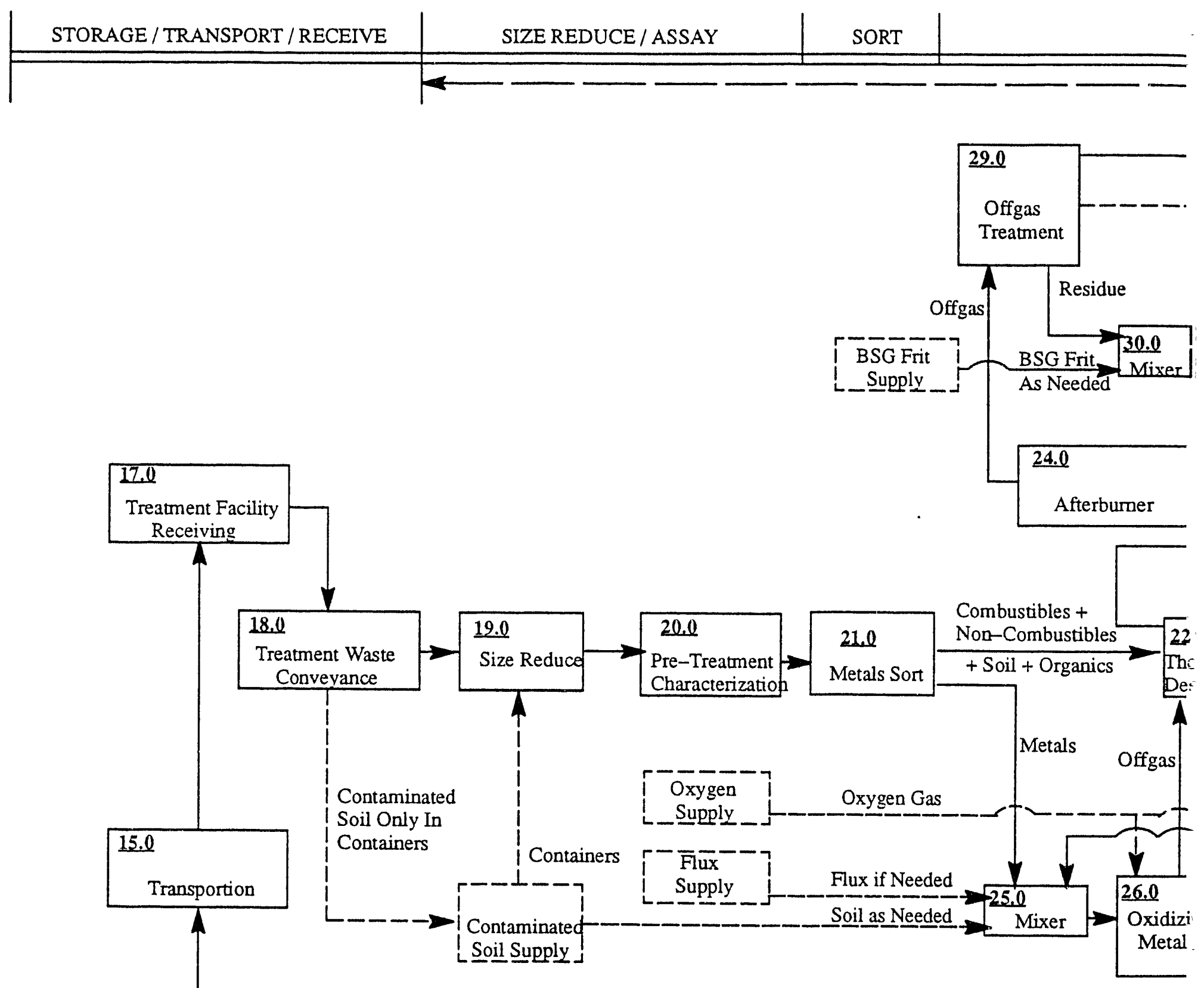

TRU / Hazardous Waste Plus All

Entrained Soil in Containers

Or

Contaminated Soil From Removed

Underburden In Containers

14.0 INEL

Interim Storage

Figure 5. (continued). 


$\frac{\text { REATMENT }}{\text { Thermal Processing Technologies }}$

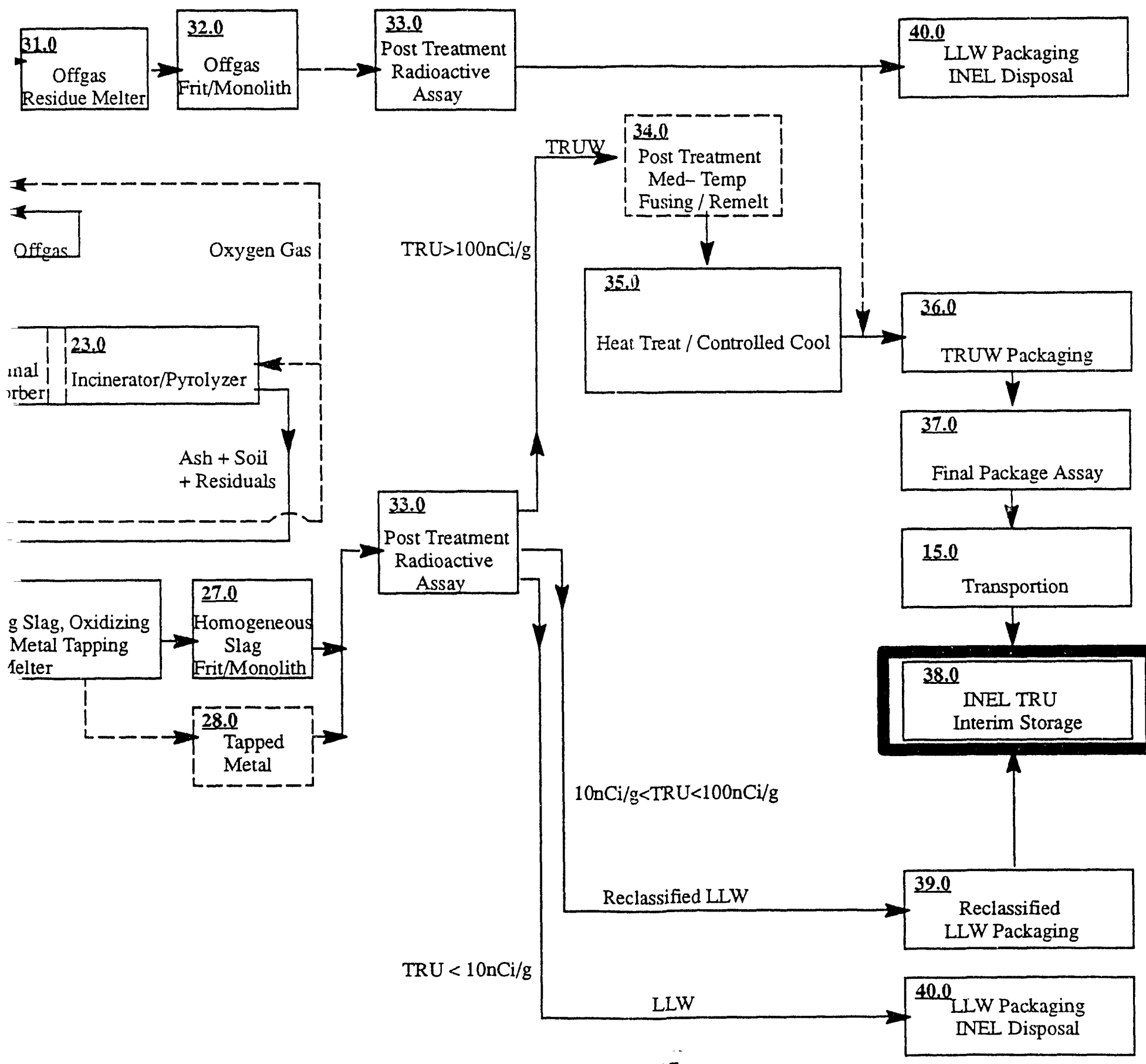




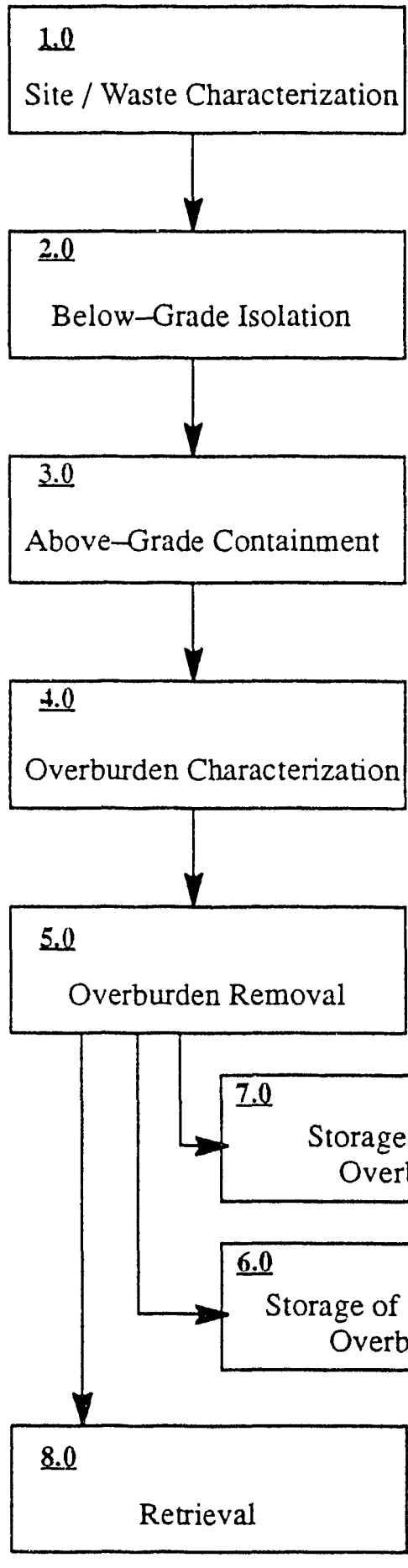

Clean Soil - Rerurn

To Pit

Figure 6. Option F-Retrieval/Interim Storage/Incineration/Melter Treatment. 
n Storage / Incineration / Melter Treatment 


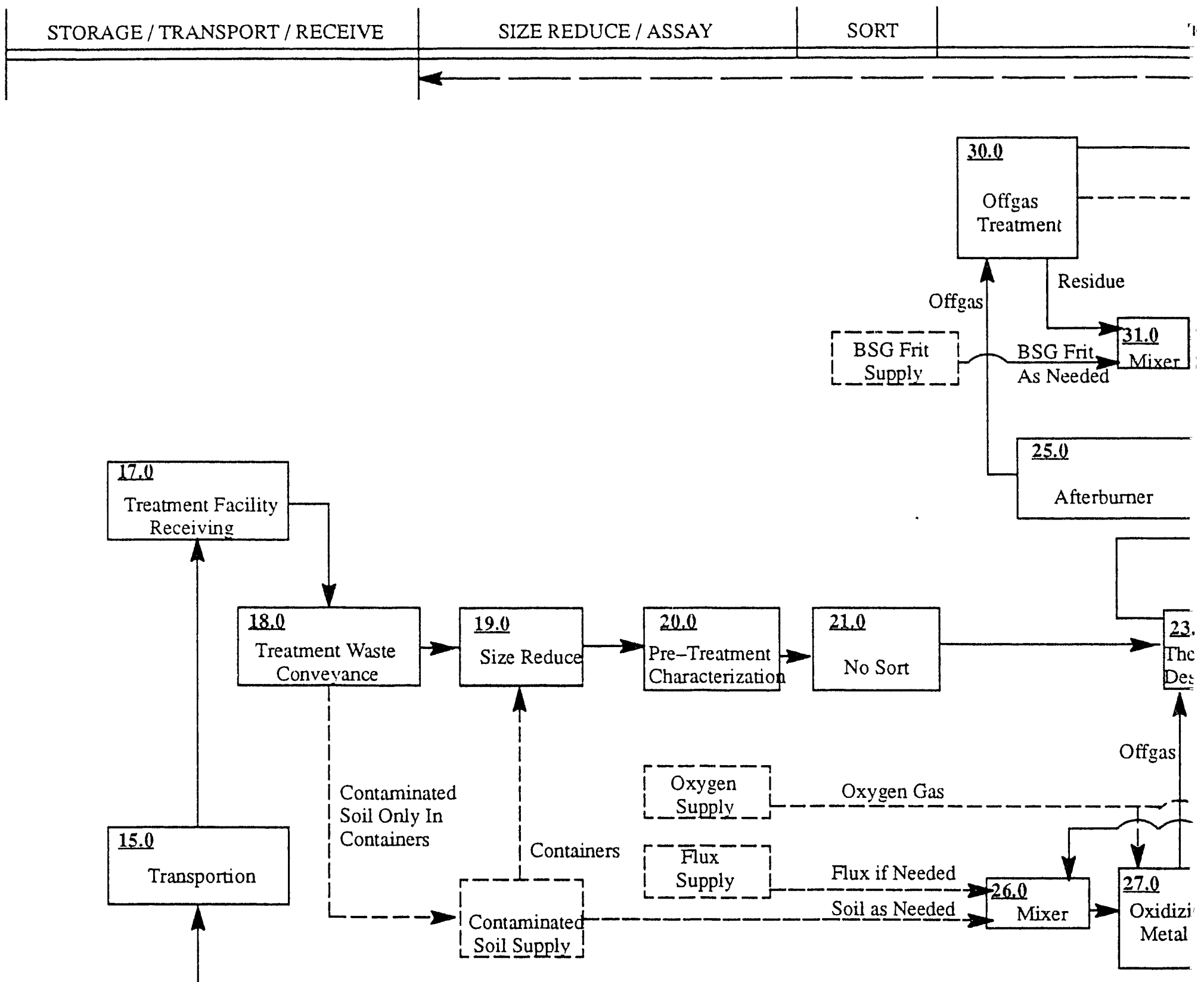

TRU / Hazardous Waste Plus All

Entrained Soil in Containers

Or

Contaminated Soil From Removed

Underburden In Containers

14.0 INEL Interim Storage

Figure 6. (continued). 

Treatment

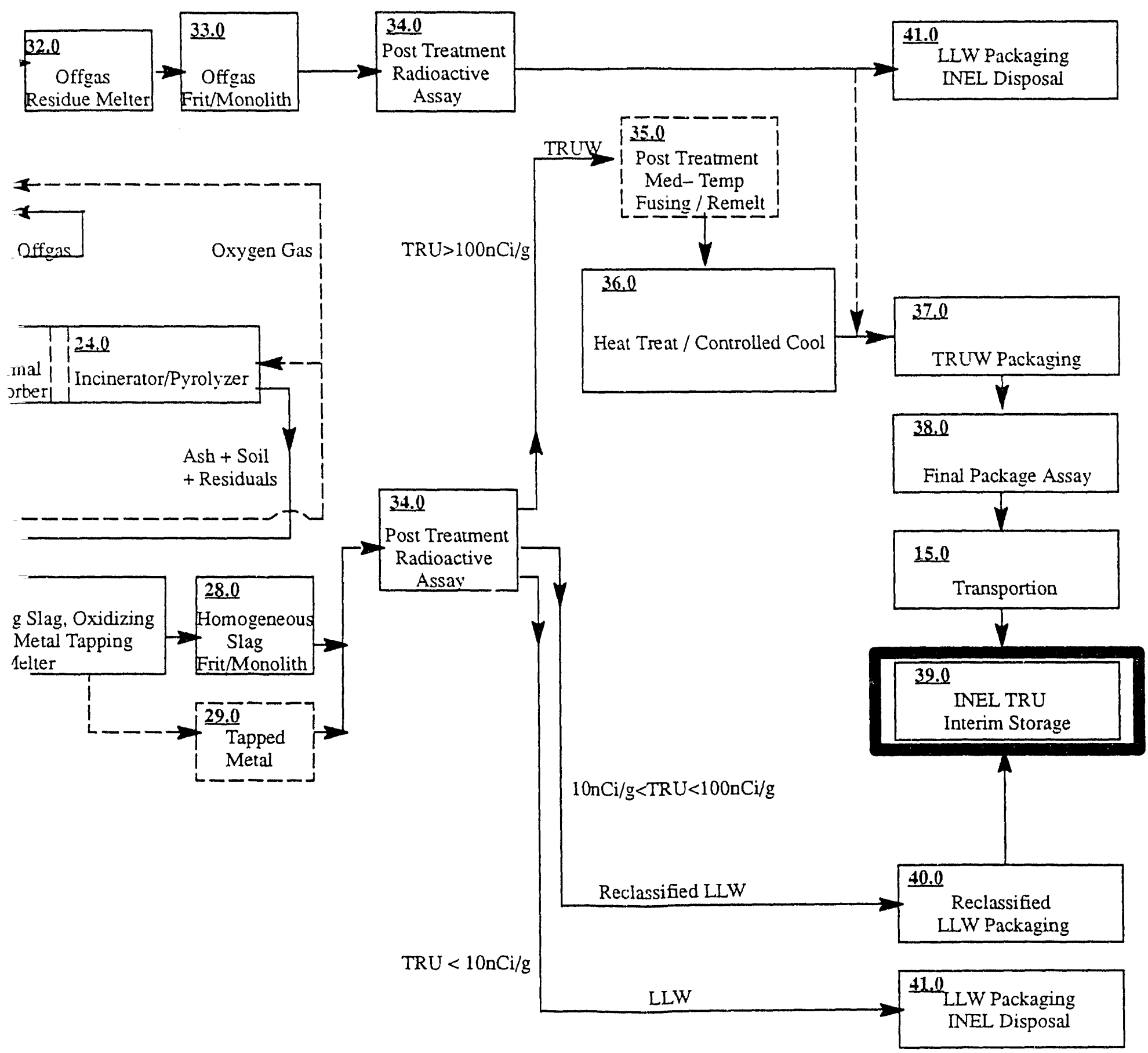




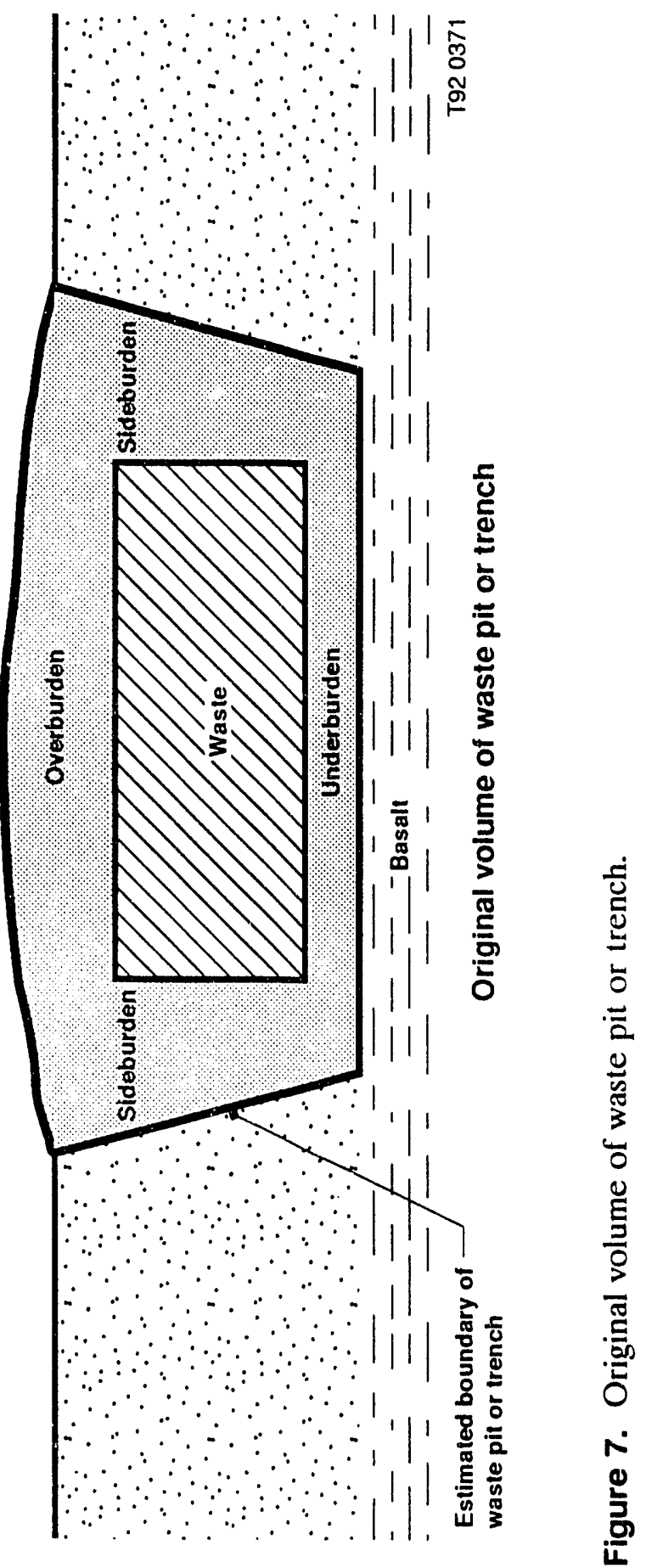




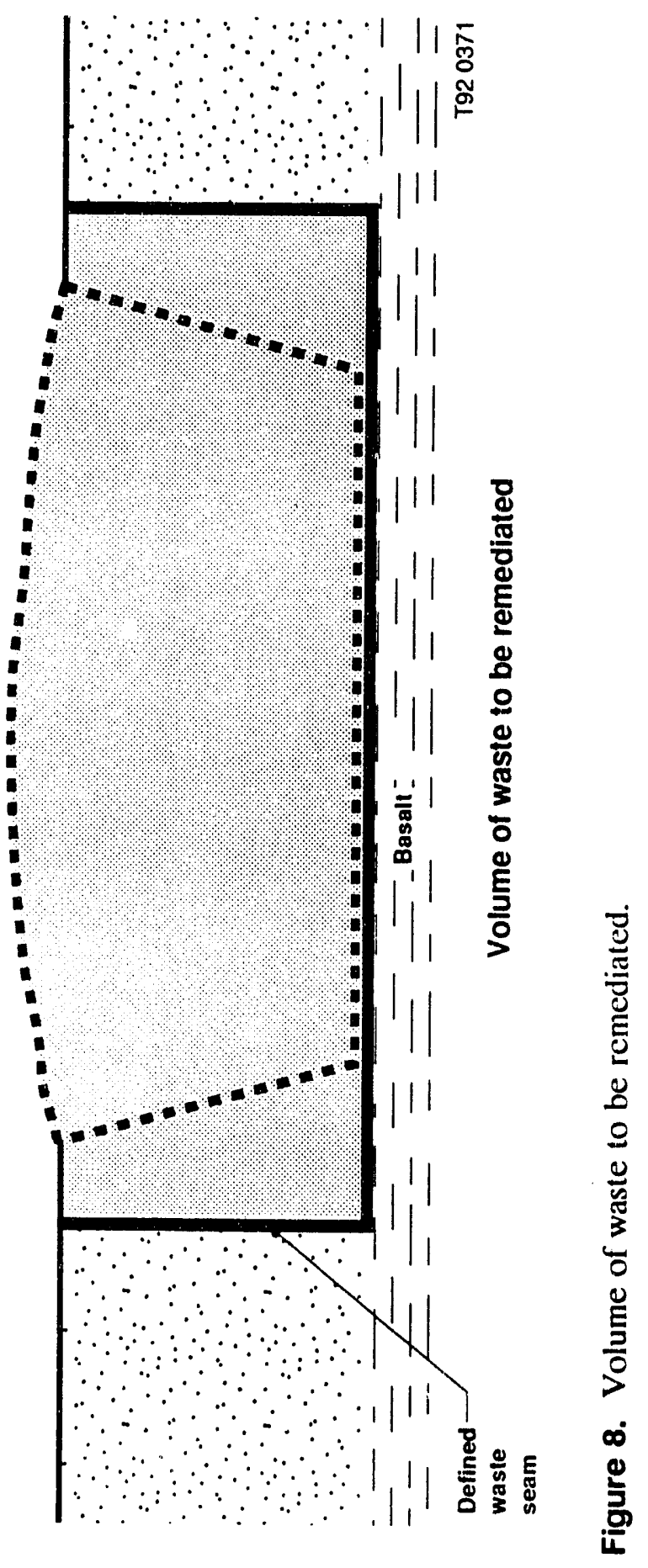




\section{Option A \\ Retrieval/Melter Treatment}

Functional Subelement 1. Site/Waste Characterization

1.1 Background Technical Information and Assumntions

1.1 .1

The waste pits were excavated to the underlying basalt layer and generally backfilled with 2 to $5 \mathrm{ft}$ of soil to provide a level floor. The waste trenches were generally excavated to the basalt layer, approximately $10 \mathrm{ft}$ down and averaged about $7 \mathrm{ft}$ wide and up to $1800 \mathrm{ft}$ long (see Reference 4). Following excavation, wastes were placed into the pits and trenches. From 1952-1963, the waste continers were stacked to optimize disposal space. During 1963-1969, the waste packages were randomly dumped into the pits and trenches in order to limit worker radiation exposure. In 1969, the waste containers were once again stacked to optimize disposal volume. Once emplaced, the wastes were backfilled with and covered with silty clay and sandy soil.

1.1.2 Physical dimensions of each waste pit and trench (including overburden) are given in Tables 1, 2, and 3 of Reference 4. Details of the characteristics of INEL RWMC soils are given in Tables 4 through 8 of Reference 4 (see Appendix A).

1.1.3 Figure 7 illustrates a cross-section of a typical Operable Unit (OU) 7-13 waste pit or trench. The figure identifies terms used throughout this report.

1.2 Input

Transuranic (TRU)-Contaminated Waste Pits and Trenches located at the INEL Subsurface Disposal Area (designated as Operable Unit 7-13).

\subsection{Requirements}

The following shall be determined during site/waste characterization:

1.3.1 Vertical boundaries of the waste pits and trenches.

1.3.2 Depth of the basalt underlying the waste pits and trenches.

1.3.3 Depth of the overburden/waste interface for each waste pit and trench.

1.3.4 Location of any outsize waste in the waste seam.

1.4 Output

Estimated boundaries of TRU-Contaminated Waste Pits and Trenches. 
Functional Subelement 2. Below-Grade Isolation

\subsection{Background Technical Information and Assumptions}

2.1.1 The basalt is assumed to offer below-grade horizontal isolation of the waste.

2.1.2 The concern of leakage through the barriers is mitigated by INEL RWMC site renovations performed under the 300-yr Flood Drainage Program.

2.1.3 The subsurface basalt is at a depth that is less than $30 \mathrm{ft}$ for any given waste pit or trench.

2.1.4 The defined waste seam will be established by an institutional review of the estimated boundaries (see Figure 8). Establishment of the defined waste seam will be performed by institutional entities. This group will be expected to identify the defined waste seam boundary for each pit or trench that includes some margin in addition to the estimated boundary values.

2.2 Input

2.2.1 Estimated boundaries of TRU-Contaminated Waste Pits and Trenches.

\subsection{Requirements}

2.3.1 Construct engineered barriers extending vertically from the surface to the basalt at the location of the defined waste seam to provide below-grade isolation of the volume to be remediated.

2.3.2 The engineered barriers shall be designed to meet or exceed all the applicable federal, state, and DOE structural safety standards for mining or excavations.

\subsection{Output}

Below-grade isolation barriers which define the volume of waste to be remediated.

Functional Subelement 3. Above-Grade Containment

\subsection{Background Technical Information and Assumptions}

3.1.1 The entire above-grade containment shall have a facility classification of moderate hazard per UCRL-15910 (see Reference 9).

3.2 Input

3.2.1 Below-grade isolation barriers of the volume to be remediated. 


\subsection{Requirements}

3.3.1 The above-grade containment structure(s) must encompass the entire volume currently being excavated.

3.3.2 The above-grade containment structure(s) shall be designed and constructed to meet the following applicable INEL building standards: General Design Criteria (DOE 6430.1A), ${ }^{10}$ Natural Phenomenon (UCRL-15910), ${ }^{9}$ DOE-ID Architectural Engineering Standards, ${ }^{11}$ Operational Safety Design Critcria Manual, ${ }^{12}$ Industry Standard Uniform Building Code (UBC), and requirements set forth in Nuclear Salcty Analysis Reports (DOE 5480.23).

3.3.3 The above-grade containment structure(s) shall have the following features:

3.3.3.1 Shall be designed to control contamination from radiological and non-radiological sources to allow maintenance repair or replacement of systems.

3.3.3.2 Shall be designed to allow all necessary activities to support ancillary activities conducted within the containment structure such as retrieval, package, and transport of excavated waste.

3.3.3.3 Shall be designed to allow ingress/egress of all equipment and personnel necessary to perform all waste retrieval activities.

3.3.3.4 Shall be designed to allow the egress of retricved waste packaged for transport.

3.3.3.5 Shall have temperature and humidity control such that the environment is regulated within the limits required for maintenance repair or replacement activities in a beta, gamma, alpha, and hazardous contaminated environment.

3.3.4 The above-grade containment structure shall contain all operations from overburden retrieval to transport to interim storage/treatment.

3.4 Output

Completed and operational containment facility over the isolated region being cxcavated.

\section{Functional Subelement $4 . \quad$ Overhurden Characterization}

\subsection{Background Technical Information and Assumptions}

4.1.1 Prior to any removal of overburden, an extensive characterization of the overburden will be performed.

4.1.2 Data from overburden characterization activities will meet data quality objectives and be useable for risk assessments. 


\subsection{Input}

4.2.1 Completed and operational containment facility over the isolated region being excavated.

\subsection{Requirements}

4.3.1 The characterization will locate any regions of contamination within the pit or trench overburden.

4.3.2 Characterization techniques must be able to sample for radioactive, including TRU, and characteristic and listed hazardous contaminants defined in the BWID Systems Analysis system requirements (see Reference 1).

\subsection{Output}

4.4.1 Location and characterization of radioactive and characteristic and listed hazardouscontaminated overburden.

Functional Subelement 5. Overburden Removal

5.1 Technical Background and Assumptions

\subsection{Input}

Location and characterization of radioactive and characteristic and listed hazardouscontaminated overburden.

5.3 Requirements

5.3.1 Up to $75 \%$ of the estimated overburden depth for each pit or trench will be removed. Sufficient overburden will be left in place so as to minimize the possibility of an inadvertent contamination exposure.

5.3.2 The removal process will separate contaminated (radioactive and hazardous) from noncontaminated overburden.

5.3.3 Overburden removal operations must control contamination from beta, gamma, alpha, and the hazardous constituents defined in the BWID Systems Analysis system requirements (see Reference 1) to levels that would allow maintenance to service or repair equipments.

5.3.4 These systems shall meet or exceed all state, federal, and DOE nuclear systems standards for explosion proof, fire protection, and suppression. 
5.4 Output

5.4.1 The completed containment facility over the region to be remediated. Up to $75 \%$ of overburden removed.

5.4.2 Contaminated (radioactive and hazardous) overburden.

5.4.3 Noncontaminated overburden.

Functional Subelement 6. $\quad$ Storage of Contaminated Overburden

6.1 Technical Background and Assumptions

6.2 Input

6.2.1 Contaminated (radioactive and hazardous) overburden.

6.3 Requirements

6.3.1 Contaminated overburden must be stored within the above-grade containment structure(s).

6.3.2 Contaminated overburden must be physically separated from retrieved noncontaminated and nonassayed overburden.

6.3.3 Stored contaminated overburden shall not cause a criticality.

6.3.4 Stored contaminated overburden shall have beta, gamma, alpha, and hazardous contamination control compatible with containment requirements of 3.3.3.1.

\subsection{Output}

6.4.1 Stored contaminated overburden.

Functional Subelement 7. Noncontaminated Overburden Storage

7.1 Technical Background and Assumptions

7.2 Input

7.2.1 Retrieved noncontaminated overburden.

7.3 Requirements

7.3.1 Retrieved noncontaminated overburden shall be stored in a weather shielded storage. 
7.3.2 If the noncontaminated storage is located outside the containment building then the noncontaminated overburden shall be surveyed to ensure that it is free of beta, gamma, alpha, and hazardous contamination prior to removal from the containment building.

\subsection{Output}

Stored noncontaminated overburden to be used to refill the remediated pit or trench.

Functional Subelement $8 . \quad \underline{\text { Retrieval }}$

\subsection{Technical Background and Assumptions}

8.1.1 The retrieval functional subelement includes all apparatus to remove all remaining overburden and the waste from the ground, control the spread of contamination during the removal, and convey the retrieved waste from the dig face to a packaging area for eventual shipment for treatment.

8.1.2 The assumption for this subelement is that criticality can be prevented.

8.2 Input

8.2.1 The completed containment facility over the region to be remediated. $75 \%$ of estimated overburden depth removed.

\subsection{Requirements}

8.3.1 The retrieval system shall exhume material within the waste seam and transfer that material to a waste conveyance system.

8.3.2 The retrieval systems shall operate within the temperature and humidity limits inside the containment structure.

8.3.3 The retrieval systems must be designed to accommodate operations, maintenance, and repair in a beta, gamma, alpha, and hazardous contamination environment.

8.3.4 The retrieval system shall be designed such that a criticality cannot occur.

8.3.5 Retrieval operations must identify and accommodate atypical waste objects (objects or material incompatible with the retrieval system) or high radiation sources. Identification may involve characterization at the dig-face. NOTE: An acceptable way to "accommodate atypical waste" objects is that the retrieval system may move these objects and stabilize them in the retrieval pit or other designated area to prevent contamination spread and/or to shield high sources of radiation as stated in system requirements (see Reference 1). Retrieval operations may bypass these 
stabilized objects and continue normal operations until such time that special case equipments and procedures will allow for their removal.

8.3.6 The retrieval system shall meet or exceed all applicable state, federal, and DOE nuclear systems standards for explosion proof, fire protection, and suppression.

8.3.7 Retrieval operations and $u$ aste packaging for conveyance will be designed such that personnel exposure to radiation will comply with DOE Order 5480.11, "Radiation Protection for Occupational Workers."

8.3.8 Retrieval operations and waste packaging for conveyance will be designed such that personnel exposure to hazardous materials will comply with all applicable OSHA standards.

8.4 Output

Exhumed waste. Waste characteristics defined in BWID Systems Analysis system requirements (see Reference 1 ).

Functional Subelement 9. Waste Conveyance

9.1 Technical Background and Assumptions

9.1.1 The conveyance functional subelement includes all apparatus to convey the retrieved waste or removed overburden within the containment structure.

9.2 Input

9.2.1 Exhumed waste. Waste characteristics defined in BWID System Analysis system requirements (see Reference 1 ).

\subsection{Requirements}

9.3.1 The waste conveyance system shall be designed so that a criticality event cannot occur.

9.3.2 The waste conveyance system must be designed to accommodate operations, maintenance, and repair in a beta, gamma, alpha, and hazardous contamination environment.

9.3.3 These systems shall meet or exceed all state, federal, and DOE nuclear systems standards for explosion proof, fire protection, and suppression.

9.3.4 The conveyance system shall operate within the temperature and humidity limits in the containment structure. 
9.3.5 The conveyance system will be designed such that personnel exposure to radiation will comply with DOE Order 5480.11, "Radiation Protection for Occupational Workers."

9.3.6 The conveyance system will be designed such that personnel exposure to hazardous materials will comply with all applicable OSHA standards.

\subsection{Output}

9.4.1 Conveyed, exhumed waste. Waste characteristics defined in system requirements (see Reference 1).

Functional Subelement $10 . \quad$ Packaging

10.1 Technical Background and Assumptions

10.2 Input

10.2.1 Conveyed, exhumed waste. Waste characteristics defined in system requirements (see Reference 1).

\subsection{Requirements}

10.3.1 The packaging system shall package and label the retrieved waste stream to meet all of the RWMC transportation requirements.

10.3.2 The packaging system shall be designed so that a criticality event cannot occur.

10.3.3 The packaging system must be designed to accommodate operations, maintenance, and repair in a beta, gamma, alpha, and hazardous contamination environment.

10.3.4 Equipment shall meet or exceed all state, federal, and DOE nuclear systems standards for explosion proof, fire protection, and suppression.

10.3.5 The packaging system shall operate within the temperature and humidity limits in the containment structure.

10.3.6 The packaging system will be designed such that personnel exposure to radiation will comply with DOE Order 5480.11, "Radiation Protection for Occupational Workers."

10.3.7 The packaging system will be designed such that personnel exposure to hazardous materials will comply with all applicable OSHA standards.

e. "Transfer, Storage, Handling and Tracking of Waste," RWMC PD-RS-1.8, April 9, 1992. 
10.4 Output

10.4 .1

Packaged waste which is in an aceeptable form for transportation to the treatment facility.

Functional Subclement 11. Transport to Treatment

11.1 Technical Background and Assumptions

11.1.1 The retrieval system can be eo-located with the treatment facility.

11.2 Input

11.2.1 Waste which is in an acceptable form for transportation to treatment.

\subsection{Requirements}

11.3.1 Meet RWMC transportation requirements (see footnote e).

11.3.2 The transport system shall be designed so that a criticality event cannot occur.

11.4 Output

11.4.1 Packaged waste delivered to the waste treatment facility receiving subelement.

Functional Subelement 12. Treatment Facility General Requirements

12.1 Technical Background and Assumptions

12.1.1 The treatment facility has a classification of Moderate Hazard per UCRL-15910) (see Reference 9).

12.1.2 The entire thermal processing line can be designed, constructed, and tested to maintain alpha contamination controls.

12.1.3 The treatment facility shall meet requirements outlined in Nuclear Safety Analysis Reports (DOE Order 5480.23).

12.2 Input

Not applicable

12.3 Requirements

12.3.1 A minimum of double confinement per DOE Order 6430.1 A shall exist between normally contaminated areas and uncontrolled areas. 
12.3.2 Equipment designs and interfaces shall be dessigned to maintain alpha, beta, and gamma contamination confinement.

12.3.3 All systems in the treatment facility shall be designed so that a criticality event cannot occur. The treatment facility will follow criticality control requirements per DOE Order $5480.5^{13}$ and DOE-ID Order 5480.5A..$^{14}$

12.3.4 These systems shall meet or exceed all state, federal, and DOE nuclear systems standards for explosion proof, fire protection, and suppression.

12.3.5 All systems in the treatment facility will be designed such that personnel exposure to radiation will comply with DOE Order 5480.11, "Radiation Protection for Occupational Workers."

12.3.6 All systems in the treatment facility will be designed such that personnel cxposure to hazardous materials will comply with all applicable OSHA standards.

12.3.7 The overall treatment facility and operational systems shall meet the requirements for a Radioactive Solid Waste Facility per DOE Order 64.30.1 A. Section 1324 (see Reference 10).

Additional high-levcl requirements are contained in Reference 15.

\subsection{Output}

Not applicable

Functional Subclement 13. Treatment Facility Receiving

13.1 Technical Background and Assumptions

13.1.1 The receiving subelement performs the functions of accepting transported material supplied by the transport-for-treatment subelement. Temporary storagc for queuing may or may not be a required function, and is dependent upon the specific technologies comprising the technology process options.

13.2 Input

Packaged waste delivered to the treatment facility.

13.3 Requirements

13.3.1 Receive waste from transportation system and store until conveyance is ready to accept waste. 


\subsection{Output}

13.4.1 Waste delivered to the treatment waste conveyance system.

Functional Subclement 14. Treatment Waste Conveyance

14.1 Technical Background and Assumptions

14.1.1 The conveyane functional subelement includes all apparatus to convey the retrieved waste or removed overburden within the treatment containment structure.

14.2 Input

14.2.1 Packaged waste delivered to the treatment waste conveyance.

14.3 Requirements

14.3.1 The waste conveyance system must be designed to accommodate operations, maintenance, and repair in a beta, gamma, alpha, and hazardous contamination environment.

14.3.2 The conveyance system shall operate within the temperature and humidity limits in the containment structure.

14.3.3 The conveyance subelement must be able to convey all the various forms of wastes within the treatment facility.

14.3.4 The conveyance subelement must convey necessary process feedstocks and process by-products.

Waste conveyance shall not change waste characteristics.

14.4 Output

14.4.1 Packaged containers containing quantities of soil and waste. The waste consists of combustibles and noncombustibles contaminated with organics, radionuclides, and heavy metals. Specifics on expected waste types and their contaminants can be found in the BWID System Analysis System Requirements (see Reference 1).

\section{Functional Subelement 15. Size Reduction}

15.1 Technical Background and Assumptions

15.1.1 Much effort has been spent on characterization of the RWMC buried waste. The basis for characterization are from past reports, sampling programs, and other efforts: however, since past practices allowed for much less stringent disposal methods, a large degree of inaceuracy must be assumed for any published numbers. 
The thermal treatment scenarios consider the waste input stream to contain these waste categories plus contaminated soil in varying amounts and percentages.

15.1.2 It is assumed that tiansportation containers will become part of the waste stream, and thus must be size reduced.

\subsection{Input}

15.2.1 Packaged containers containing quantities of soil and waste. The waste consists of combustibles and noncombustibles contaminated with organics, radionuclides, and heavy metals. Specifics on expected waste types and their contaminants can be found in BWID Systems Analysis System Requirements (see Reference 1).

\subsection{Requirements}

15.3.1 Process must be capable of reducing size of packaged waste to mect size requirements of downstream treatment process.

\subsection{Output}

\subsubsection{Sizc-reduced waste stream.}

\section{Functional Subelement 16. Pre-Treatment Characterization}

16.1 Technical Background and Assumptions

16.2 Input

16.2.1 Size-reduced waste stream.

16.3 Requirements

16.3.1 Monitor for gross volatile organic compounds (VOCs) identified in BWID System Analysis System Requirements (sec Reference 1) to assist in melter performance and maintain safe operations.

16.3.2 Monitor for gross radionuclides identified in BWID System Analysis System Requirements (see Reference 1) and radiation levels to assist in process safety controls and quality control of the final waste form.

16.3.3 Monitor as necessary for other gross concentrations of constituents which are difficult to process such as chlorides, High Vapor Pressure Metals (HVPMs), and sulfur. The constituents which are difficult to process are determined by the melting technology chosen.

16.3.4 Data acquisition is compatible with down stream processes. 
16.4 Output

16.4.1 Entire waste stream not changed from input.

16.4.2 Data on VOCs, radionuclides, radiation intensity, and other constituents which are difficult to process.

Functional Subclement 17. $\quad$ No Sort

17.1 Technical Background and Assumptions

17.1.1 is assumed that atypical waste is not included in the main waste stream.

17.2 Input

17.2.1 Entire waste stream from pre-treatment assay and size reduction.

17.3 Requirements

17.3.1 None.

17.4 Output

17.4.1 Same as input.

Functional Subclement 18. Mixer

18.1 Technical Background and Assumptions

18.2 Input

18.2.1 Full waste stream from the radioactive and VOC assay subsystem.

18.2.2 Flux as required for melter process control.

18.2.3 Additional soil from removed underburden if needed for melter process control and final waste form quality control.

18.3 Requirements

18.3.1 Mixes and blends three feedstock in proper proportion to mect melter input requirements.

18.4 Output

18.4.1 Feedstock to the melter. 
Functional Subelement 19. Hi-Temperature Pyrolyzing Gas, Oxidizing Slag Melter

19.1 Technical Background and Assumptions

19.1.1 This option combines incineration technology and melter technology into one operable unit. Units which perform these tasks are commercially available; however, none have been proven for operation in an alpha environment. It is assumed that this type of melter can be successfully operated in an alpha environment.

Note: estimated melter operating temperature is $>1600^{\circ} \mathrm{C}$ based on References 15 , 16. and 17 .

19.2 Input

19.2.1 Blended feedstock from the mixer. Proportions controlled via inputs to the mixer such that output matrix meets output quality control requirements.

19.2.2 Oxygen gas.

19.3 Requirements

19.3.1 The melter shall be capable of destroying all organics and melting all waste forms identified in the input requirements (see Reference 1), interstitial soil, and contaminated overburden.

19.3.2 Operating mode of pyrolyzing atmosphere is above the slag surface, and oxidizing is below the slag surface.

19.3.3 Produce a waste form that is no longer considered a hazardous waste per 40CFR261.

19.4 Output

19.4.1 Pyrolized offgas waste stream to the afterburner subelement.

19.4.2 Molten slag to the slag frit/monolith subelement.

19.4.3 Tapped molten metals to the molten metals subsystem.

Functional Subelement 20. $\quad$ Afterburner

20.1 Technical Background and Assumptions

20.1.1 The output stream from the afterburner is assumed to contain $\mathrm{H}_{2} \mathrm{O} ; \mathrm{CO}_{2}$; some High Vapor Pressure Metals (HVPMs) such as mercury, lcad, cadmium, arsenic. etc.: HVPM oxides: halogens; sulfur compounds; combusted organics; particulates; 
and potential radionuclides ( $\mathrm{Cs}^{1.37}$, potential minor quantities of TRU oxides, and other LLW radionuclides).

20.1.2 One possible design is that the afterburner maintains the offgas stream for a minimum time at a minimum temperature (approximately $>2 \mathrm{sec}$ at $>1010{ }^{\circ} \mathrm{C}$ ) to cnsure complete combustion.

20.2 Input

20.2.1

Pyrolyzed offgas from the melter.

20.3 Requirements

20.3.1 The afterburner shall ensure 99.9999 percent (1 part in $10^{6}$ ) combustion of all organics in the offgas stream.

20.4 Output

20.4.1 Fully combusted offgas stream.

Functional Subclement 21. $\quad$ Homogeneous Slag Frit/Monolith

21.1 Technical Background and Assumptions

21.1.1 The composition of the molten slag output stream is assumed to be an iron-enriched basalt matrix with dissolved metal oxides, and TRU plus LLW contaminants. This assumption is based on experimental and calculated work as reported in references $16,17,18$, and 19 .

21.1.2 The output of the melter is assumed to be slag frit or monolith, whichever form enables a high quality, high reliability radioactive assay.

\subsection{Input}

21.2.1 Tapped molten slag from the melter.

\subsection{Requirements}

21.3.1 Receive and handle the molten slag from the melter, and cast it into monoliths or process into a frit form.

21.3.2 The waste form matrix will prevent the release of radionuclides and heavy metals.

\subsection{Output}

21.4.1 Slag in the form of a frit or monolith compatible with downstream processes. 


\section{Functional Subelement 22. Tapped Metal}

\subsection{Technical Background and Assumptions}

22.1.1 No radionuclides, or only very minor quantities of radionuclides are expected to be partitioned into the molten metals stream. The radionuclides are expected to be partitioned into the slag, with potentially some carryover into the offgas system. However, radiological controls must still be emplaced on the metals stream.

22.1 .2

The metals contained in the molten metal output stream are assumed to be mainly iron $(\mathrm{Fe})$ with trace other metals included.

22.1.3 A high reliability assay of the metals is assumed to be possible in the monolith form.

\subsection{Input}

22.2.1 Molten metal tapped from the melter.

\subsection{Requirements}

22.3.1 Receive and handle the molten metal from the melter and cast into monolith forms.

22.3.2 Produce a waste form that is no longer considered a hazardous waste per 40CFR261.

\subsection{Output}

A metal monolith waste form.

Functional Subelement 23. Offgas Treatment

23.1 Technical Background and Assumptions

23.1.1 The olfgas stream to the offgas treatment system is assumed to contain $\mathrm{H}_{2} \mathrm{O}, \mathrm{CO}_{2}$, High Vapor Pressure Metals (HVPMs, mercury, lcad, cadmium, arsenic, etc.), HVPM oxides, halogens, sulfur compounds, combusted organics, particulates, and some radionuclides $\left(\mathrm{Cs}^{137}\right.$, potential minor quantities of TRU oxides, and other LLW radionuclides).

23.1.2 The offgas unabated release calculations are assumed to confirm the potential for discharge of radionuclide resulting in effective dose equivalents greater than allowable per 40CFR61.92. 
23.2 Input

23.2.1

Offgas stream from the thermal treatment processes.

\subsection{Requirements}

The offgas treatment system shall clean the offgas stream of all constituents to allow operations within applicable State and Federal air permit requirements.

DOE 6430.1a, 40CFR60, 40CFR61, and ANSI N13.1, the offgas treatment system shall be equipped with air monitoring instruments to detect radionuclides and hazardous constituents listed in the BWID Systems Analysis System Requirements (see Reference 1). The final released offgas effluent shall be monitored for any normally or accidentally released radionuclides via an isokinetic sampling system.

23.3.3 The offgas system must be maintained at a sufficient negative pressure to draw all gaseous flows through the systems and still maintain adequate negative pressure at the most remote location.

23.4 Output

23.4.1 A cleaned offgas gaseous waste stream which meets all appropriate permit requirements.

23.4.2 One or more offgas residue streams.

23.4.3 Process waste stream specific to the offgas treatment chosen.

Functional Subelement 23A. Zero Emissions Offgas Treatment

(Optional)

23A.1 Technical Background and Assumptions

23A.1.1 The offgas stream to the offgas treatment system is assumed to contain $\mathrm{H}_{2} \mathrm{O}, \mathrm{CO}_{2}$, High Vapor Pressure Metals (HVPMs, mercury, lead, cadmium, arsenic, etc.), HVPM oxides, halogens, sulfur compounds, combusted organics, particulates, and some radionuclides $\left(\mathrm{Cs}^{137}\right.$, potential minor quantities of TRU oxides, and other LLW radionuclides).

23A.1.2 Requirements for this type of offgas system are considered to exceed the requirements necessary to meet present day permitting applications. However, permitting actions are assumed to be greatly enhanced with the stricter requirements due to the decreased nature of olfgas emissions.

23A.1.3 Zero emissions offgas systems of this type are assumed to be only in the research and development stage. Proven technology is assumed to be nonexistent. A large development effort is assumed to be required for this option. 
$2.3 A .2$ Input

23A.2.2 Offgas stream from the thermal treatment processes.

2.3A.3 Requirements

23A.3.1 The zero emissions offgas treatment system option shall clean the offgas stream of all constituents with the exception of a minor stream of inert gas. NOTE: These restrictions surpass the present permit requirements for operations. Any minor remaining offgas stream must include full high efficiency particulate air (HEPA) filtering of the stream.

23A.3.2 This option for offgas treatment must convert all offgas constituents to solid or liquid form for further disposition.

23A.4 Output

23A.4.1 Potential offgas stream consisting of inert gas.

23A.4.2 An offgas residue stream in liquid or solid form.

Functional Subclement 24. $\quad \underline{\text { Mixer }}$

24.1 Technical Background and Assumptions

24.2 Input

24.2.1 Residue from the offgas treatment subsystem.

24.2.2 Borosilicate glass (BSG) frit.

24.3 Requirements

24.3.1 Mixes and blends feedstock to meet melter input requirements.

24.4 Output

24.4.1 Blended BSG and residue feedstock to the melter.

Functional Subelement 25. Offgas Residue Melter

25.1 Technical Background and Assumptions

25.1.1 Assumed melter temperature is a nominal 110()$^{\circ} \mathrm{C}$ based on operating temperatures for melters designed for vitrification of high-level waste (HLW) using borosilicate glass. 
25.2 Input

25.2.1

Blended feedstock from the mixer subelement consisting of residue from the offgas system and BSG frit.

\subsection{Requirements}

25.3.1 Operating temperature high enough to melt the BSG frit and the residue, yet low enough to hold the contaminants (high vapor pressure metals, metal oxides, radionuclides, etc.) in solution.

25.3.2 The output must be compatible with downstream processes.

25.3.3 Produce a waste form that is no longer considered a hazardous waste per 40CFR261.

25.4 Output

25.4.1 Molten slag.

25.4.2 Offgas effluent.

Functional Subelement 26. Offgas Frit or Monolith Subsystem

26.1 Technical Background and Assumptions

26.1.1 The composition of the molten slag output stream is assumed to be a borosilicate glass matrix with dissolved metal oxides, and potential very minor quantities of TRU plus LLW contaminants.

26.2 Input

26.2.1

Molten slag from the offgas residue melter subelement.

26.3 Requirements

26.3.1 Receive and handle the molten slag from the melter, and cast it into monoliths or process into a frit form.

26.3.2 Output is compatible with downstream processes

26.4 Output

26.4.1 Homogeneous BSG slag in the form of a frit or monolith. 
Functional Subelement 27. Post-Treatment Radioactive Assay

\subsection{Technical Background and Assumptions}

27.1.1 Assume that pretreatment characterization will not satisfy the requirements for classifying output waste form.

An advantage for thermally processing this type of waste is to convert the asreceived waste stream into a form which will enhance the ability to obtain TRU concentration data with reduced uncertainty.

27.1.3 The bases for this reduction in uncertainty of assay data are:

- The geometry of the assay form can be optimized for the assay equipment (geometry of choice enables consistent geometrical calibration factors).

- Vitrification and homogenization eliminate density variances.

- Vitrification and homogenization eliminate radionuclide distribution variances (fully dissolved radionuclides and complete mixing).

- Vitrification and homogenization enhance the predictability of self shielding (alpha) unknowns.

- Vitrification and geometry of choice allow for reduced assay time due to assay of a known form with decreased variances and enables assay data to be collected at a waste throughput rate of tons per day.

- Vitrification and enhanced assay capability allow for post-treatment sort of TRU waste and L.LW based on reliable and consistent assay data.

- Vitrification and enhanced assay capability increases the ability to identify radionuclides and to quantify concentrations of the radionuclides. This enhanced capability increases the credibility of the data and allows for further rational disposition decisions.

27.2 Input

27.2.1 Homogeneous IEB or BSG frit or monolith from the thermal treatment subsystems (BSG from offgas stream or IEB from the waste stream).

27.3 Requirements

27.3.1 Identify and quantify radionuclides found in Reference 1 to meet the assay requirements necessary to assign waste as LLW, reclassified LLW, or Transuranic as follows: 
- $\quad$ TRU $>100 \mathrm{nCi} / \mathrm{g}-$ Transuranic Waste

- $10 \mathrm{nCi} / \mathrm{g}<\mathrm{TRU}<100 \mathrm{nCi} / \mathrm{g}$ - Reclassified LLW

- $T R U<10 \mathrm{nCi} / \mathrm{g}-\mathrm{LLW}$

27.4 Output

27.4.1 Radioactive assay data.

27.4.2 An unchanged frit or monolith waste form.

Functional Subelement 28. $\quad$ Post-Treatment Medium Temperature Fusing/Re-melt

28.1 Technical Background and Assumptions

28.1.1 This subsystem may be unnecessary if a monolith is cast during initial thermal treatment. The output of frit or monolith from the primary thermal treatment subsystem is dependant on the physical form required to enhance the assay capabilities and produce lower uncertainty reliability assay data.

28.2 Input

28.2.1 Frit or monolith waste from the assay subsystem with TRU $>100 \mathrm{nCi} / \mathrm{g}$.

28.3 Requirements

28.3.1 Fuse or re-melt the IEB frit and cast it into a monolith. (Medium temperature melter operating at a nominal $1400^{\circ} \mathrm{C}$.)

28.4 Output

28.4.1 A monolithic IEB waste form.

Functional Subelement 29. $\quad$ Heat Treat/Controlled Cool

29.1 Technical Background and Assumptions

29.1.1 The purpose of this functional subelement is to change the microstructure of the cast monolith waste form such that the resulting waste form has low leach rate and high durability.

29.1.2 This subelement along with the fusing/re-melt subclement may be unnecessary functions if assay systems are identified that can provide high quality, reliable data from a monolith cast block direct from the primary thermal process subelement. 
29.2 Input

29.2.1 The input for this sub-element is a monolith waste form either direct from the primary thermal process subsystem via the assay subsystem or from the fusing/re-melt melter subclement.

29.3 Requirements

29.3.1 Control cooling to optimize the microstructure in order to meet leach rate and durability requirements.

29.3.2

The subsystem shall include nondestructive test capabilities to verify the integrity of the final waste form.

29.4 Output

29.4.1 Iron-enriched basalt (IEB) monolithic waste form.

Functional Subclcment 30. TRU Waste Packaging

30.1 Technical Background and Assumptions

30.1.1 The designated disposition is for interim storage at the INEL pending resolution and opening of a permanent repository for TRU/TRU-Mixed buried waste.

3() .2 Inpul

30.2.1 Monolithic waste forms with concentration of $\mathrm{TRU}>100 \mathrm{nCi} / \mathrm{g}$.

30.3 Requirements

30.3.1 Packaging requirements shall meet current INEL TRU Waste Acceptance Criteria (see Reference 7) and the RWMC transportation requirements (see footnote c).

30.4 Output

Packaged TRU > $100 \mathrm{nCi} / \mathrm{g}$ waste.

Functional Subclement 31. Final Package Assay

31.1 Technical Background and Assumptions

31.2 Input 
31.3 Requirements

31.3.1 Final assay and external contamination swipe surveys for INEL TRU Waste Acceptance Criteria (WAC).

31.4 Output

31.4.1. Packaged TRU $>100 \mathrm{nCi} / \mathrm{g}$ waste.

Functional Subelement 32. Transportation

32.1 Technical Background and Assumptions

32.1.1 Transportation to interim storage can occur within the RWMC and thus will not have to fully comply with the EG\&G Hazardous Material Transportation Manual. ${ }^{f}$

32.2 Input

32.2.1 Waste which is in an acceptable form for transportation to and storage in interim storage.

32.3 Requirements

32.3.1 RWMC transportation requirements (see footnote e).

32.4 Output

32.4.1 Packaged waste and its associated assay information delivered to interim storage facilities.

Functional Subelement 33. INEL TRU Interim Storage

33.1 Technical Background and Assumptions

33.2 Input

33.2.1 Packaged TRU $>100 \mathrm{nCi} / \mathrm{g}$ waste.

33.3 Requirements

33.3.1 Retrievable storage at the INEL.

f. EG\&G Hazardous Material Transportation Manual (Traffic Management, Ext. 2414). 
33.4 Output

33.4 .1

Packaged TRU > $100 \mathrm{nCi} / \mathrm{g}$ waste.

Functional Subelement 34. Reclassified Low-Level Waste Packaging

34.1 Technical Background and Assumptions

34.1 .1

Assume reclassified LLW has same INEL WAC as LLW.

34.2 Input

34.2.1 Reclassified LLW waste in a frit or monolith form with a concentration of $10 \mathrm{nCi} / \mathrm{g}$ $<$ TRU $<100 \mathrm{nCi} / \mathrm{g}$.

34.3 Requirements

34.3.1 Packaging shall be per INEL LLW Waste Acceptance Criteria (see Reference 6).

34.3.2 Disposal shall be per INEL LLW disposal criteria (see Reference 6).

34.4 Output

34.4.1 Packaged $10 \mathrm{nCi} / \mathrm{g}<\mathrm{TRU}<100 \mathrm{nCi} / \mathrm{g}$ waste in an approved container.

Functional Subelement 35. Low-Level Waste Packaging INEL Disposal

35.1 Technical Background and Assumptions

35.1.1 The waste derived from fixing the offgas residue into borosilicate glass is assumed to be LLW. The potential for TRU elements to be carried off into the offgas waste stream is considered to be very small. Classification as LLW is verified in the assay sub-element (50.0).

35.2 Input

35.2.1 Low-level waste in a borosilicate glass frit or monolith form.

35.3 Requirements

35.3.1 Packaging shall be per INEL LLW Waste Acceptance Criteria (see Reference 6).

35.4 Output

35.4.1 Packaged LLW. 


\section{Option B \\ Retrieval/Metals Sort/Thermal Treatment}

Functional Subelement 1. Site/Waste Characterization

\subsection{Background Technical Information and Assumptions}

1.1.1 The waste pits were excavated to the underlying basalt layer and generally backfilled with 2 to 5 ft of soil to provide a level floor. The waste trenches were generally excavated to the basalt layer, approximately $10 \mathrm{ft}$ down and averaged about $7 \mathrm{ft}$ wide and up to $1800 \mathrm{ft}$ long (see Reference 4). Following excavation, wastes were placed into the pits and trenches. From 1952-1963, the waste containers were stacked to optimize disposal space. During 1963-1969, the waste packages were randomly dumped into the pits and trenches in order to limit worker radiation exposure. In 1969, the waste containers were once again stacked to optimize disposal volume. Once emplaced, the wastes were backfilled with and eovered with silty clay and sandy soil.

1.1.2 Physical dimensions of each waste pit and trench (including overburden) are given in Tables 1, 2, and 3 of Reference 4. Details of the characteristics of INEL RWMC soils are given in Tables 4 through 8 of Reference 4 (see Appendix A).

1.1.3 Figure 7 illustrates a cross-section of a typical Operable Unit (OU) 7-13 waste pit or trench. The figure identifics terms used throughout this report.

1.2 Input

Transuranic (TRU)-Contaminated Waste Pits and Trenches located at the INEL Subsurface Disposal Area (designated as Operable Unit 7-13).

\subsection{Requirements}

The following shall be determined during siie/waste characterization:

1.3.1 Vertical boundaries of the waste pits and trenches.

1.3.2 Depth of the basalt underlying the waste pits and trenches.

1.3.3 Depth of the overburden/waste interface for each waste pit and trench.

1.3.4 Location of any outsize waste in the waste seam.

\subsection{Output}

Estimated boundaries of TRU-Contaminated Waste Pits and Trenches. 
Functional Subelement 2. Below-Grade Isolation

\subsection{Background Technical Information and Assumptions}

2.1.1 The basalt is assumed to offer below-grade horizontal isolation of the waste.

2.1.2 The concern of leakage through the barriers is mitigated by INEL RWMC site renovations performed under the 300-yr Flood Drainage Program.

2.1.3 The subsurface basalt is at a depth that is less than $30 \mathrm{ft}$ for any given waste pit or trench.

2.1.4 The defined waste seam will be established by an institutional review of the estimated boundaries (see Figure 8). Establishment of the defined waste seam will be performed by institutional entities. This group will be expected to identify the defined waste seam boundary for each pit or trench that includes some margin in addition to the estimated boundary values.

\subsection{Input}

2.2.1 Estimated boundaries of TRU-Contaminated Waste Pits and Trenches.

\subsection{Requirements}

2.3.1 Construct engineered barriers extending vertically from the surface to the basalt at the location of the defined waste seam to provide below-grade isolation of the volume to be remediated.

The engineered barriers shall be designed to meet or exceed all the applicable federal, state, and DOE structural safety standards for mining or excavations.

\subsection{Output}

Below-grade isolation barriers which define the volume of waste to be remediated.

\section{Functional Subelement 3. Above-Grade Containment}

\subsection{Background Technical Information and Assumptions}

3.1.1 The entire above-grade containment shall have a facility classification of moderate hazard per UCRL-15910 (see Reference 9).

\subsection{Input}

3.2.1 Below-grade isolation barriers of the volume to be remediated. 


\subsection{Requirements}

3.3.1 The above-grade containment structure(s) must encompass the entire volume currently being excavated.

3.3.2 The above-grade containment structure(s) shall be designed and constructed to meet the following applicable INEL building standards: General Design Criteria (DOE 6430.1A), ${ }^{10}$ Natural Phenomenon (UCRL-15910), ${ }^{9}$ DOE-ID Architectural Enginecring Standards, ${ }^{11}$ Operational Safety Design Criteria Manual, ${ }^{12}$ Industry Standard Uniform Building Code (UBC), and the Nuclear Safety Analysis Reports (DOE Order 5480.23).

3.3.3 The above-grade containment structure(s) shall have the following features:

3.3.3.1 Shall be designed to control contamination from beta, radiological and nonradiological sources to allow maintenance repair or replacement of systems.

3.3.3.2 Shall be designed to allow all necessary activities to support ancillary activitics conducted within the containment structure such as retrieval, package, and transport of excavated waste.

3.3.3.3 Shall be designed to allow ingress/egress of all equipment and personnel necessary to perform all waste retrieval activities.

3.3.3.4 Shall be designed to allow the egress of retrieved waste packaged for transport.

3.3.3.5 Shall have temperature and humidity control such that the environment is regulated within the limits required for maintenanee repair or replacement activities in a beta, gamma, alpha, and hazardous contaminated environment.

3.3.4 The above-grade containment structure shall contain all operations from overburden retrieval to transport to interim storage/treatment.

\subsection{Output}

3.4 .1

Completed and operational containment facility over the isolated region being excéavated.

Functional Subelement 4. Overburden Characterization

\subsection{Background Technical Information and Assumptions}

4.1.1 Prior to any removal of overburden, an extensive characterization of the overburden will be performed.

4.1.2 Data from overburden characterization activities will meet data quality objectives and be useable for risk assessments. 


\subsection{Input}

4.2.1 Completed and operational containment facility over the isolated region being excavated.

\subsection{Requirements}

The characterization will locate any regions of contamination within the pit or trench overburden.

Characterization techniques must be able to sample for radioactive, including TRU, and characteristic and listed hazardous contaminants defined in the BWID Systems Analysis system requirements (see Reference 1).

\subsection{Output}

Location and characterization of radioactive and characteristic and listed hazardouscontaminated overburden.

Functional Subelement 5. Overburden Removal

\subsection{Technical Background and Assumptions}

\subsection{Input}

Location and characterization of radioactive and characteristic and listed hazardouscontaminated overburden.

\subsection{Requirements}

5.3.1 Up to $75 \%$ of the estimated overburden depth for each pit or trench will be removed. Sufficient overburden will be left in place so as to minimize the possibility of an inadvertent contamination exposure.

5.3.2 The removal process will separate contaminated (radioactive and hazardous) from noncontaminated overburden.

5.3.3 Overburden removal operations must control contamination from beta, gamma, alpha, and the hazardous constituents defined in the BWID Systems Analysis systen requirements (see Reference 1) to levels that would allow maintenance to service or repair equipments.

5.3.4 These systems shall meet or exceed all state, federal, and DOE nuclear systems standards for explosion proof, fire protection, and suppression. 
5.4 Output

5.4.1 The completed containment facility over the region to be remediated. Up to $75 \%$ of overburden removed.

5.4.2 Contaminated (radioactive and hazardous) overburden.

5.4.3 Noncontaminated overburden.

Functional Subelement $6 . \quad$ Storage of Contaminated Overburden

6.1 Technical Background and Assumptions

6.2 Input

6.2.1 Contaminated (radioactive and hazardous) overburden.

6.3 Requirements

6.3.1 Contaminated overburden must be stored within the above-grade containment structure(s).

6.3.2 Contaminated overburden must be physically separated from retrieved noncontaminated and nonassayed overburden.

6.3.3 Stored contaminated overburden shall not cause a criticality.

6.3.4 Stored contaminated overburden shall have beta, gamma, alpha, and hazardous contamination control compatible with containment requirements of 3.3.3.1.

6.4 Output

6.4.1 Stored contaminated overburden.

Functional Subelement 7. Noncontaminated Overburden Storage

7.1 Technical Background and Assumptions

7.2 Input

7.2.1 Retrieved noncontaminated overburden.

7.3 Requirements

7.3.1 Retrieved noncontaminated overburden shall be stored in a weather shielded storage. 
7.3.2 If the noncontaminated storage is located outside the containment building then the noncontaminated overburden shall be surveyed to ensure that it is free of beta, gamma, alpha, and hazardous contamination prior to removal from the containment building.

\subsection{Output}

Stored noncontaminated overburden to be used to refill the remediated pit or trench.

Functional Subelement $8 . \quad$ Retrieval

\subsection{Technical Background and Assumptions}

8.1.1 The retrieval functional subelement includes all apparatus to remove all remaining overburden and the waste from the ground, control the spread of contamination during the removal, and convey the retrieved waste from the dig face to a packaging area for eventual shipment for treatment.

8.1.2 The assumption for this subelement is that criticality can be prevented.

8.2 Input

8.2.1 The completed containment facility over the region to be remediated. $75 \%$ of estimated overburden depth removed.

\subsection{Requirements}

8.3.1 The retrieval system shall exhume material within the waste seam and transfer that material to a waste conveyance system.

8.3.2 The retrieval systems shall operate within the temperature and humidity limits inside the containment structure.

8.3.3 The retrieval systems must be designed to accommodate operations, maintenance, and repair in a beta, gamma, alpha, and hazardous contamination environment.

8.3.4 The retrieval system shall be designed such that a criticality cannot occur.

8.3.5 Retrieval operations must identify and accommodate atypical waste objects (objects or material incompatible with the retrieval system) or high radiation sources. Identification may involve characterization at the dig-face. NOTE: An acceptable way to "accommodate atypical waste" objects is that the retrieval system may move these objects and stabilize them in the retrieval pit or other designated area to prevent conlamination spread and/or to shield high sources of radiation as stated in system requirements (see Reference 1). Retrieval operations may bypass these 
stabilized objects and continue normal operations until such time that special case equipments and procedures will allow for their removal.

8.3.6 The retrieval system shall meet or exceed all applicable state, federal, and DOE nuclear systems standards for explosion proof, fire protection, and suppression.

8.3.7 Retrieval operations and waste packaging for conveyance will be designed such that personnel exposure to radiation will comply with DOE Order 5480.11, "Radiation Protection for Occupational Workers."

8.3.8 Retrieval operations and waste packaging for conveyance will be designed such that personnel exposure to hazardous materials will comply with all applicable OSHA standards.

\subsection{Output}

Exhumed waste. Waste characteristics defined in BWID Systems Analysis system requirements (see Reference 1 ).

Functional Subelement $9 . \quad$ Waste Conveyance

9.1 Technical Background and Assumptions

9.1.1 The conveyance functional subelement includes all apparatus to convey the retrieved waste or removed overburden within the containment structure.

9.2 Input

9.2.1 Exhumed waste. Waste characteristics defined in BWID System Analysis system requirements (see Reference 1).

\subsection{Requirements}

9.3.1 The waste conveyance system shall be designed so that a criticality event cannot occur.

9.3 .2

The waste conveyance system must be designed to accommodate operations, maintenance, and repair in a beta, gamma, alpha, and hazardous contamination environment.

9.3.3 These systems shall meet or exceed all state, federal, and DOE nuclear systems standards for explosion proof, fire protection, and suppression.

9.3 .4

The conveyance system shall operate within the temperature and humidity limits in the containment structure. 
9.3.5 The conveyance system will be designed such that personnel exposure to radiation will comply with DOE Order 5480.11, "Radiation Protection for Occupational Workers."

9.3.6 The conveyance system will be designed such that personnel exposure to hazardous materials will comply with all applicable OSHA standards.

\subsection{Output}

9.4.1 Conveyed, exhumed waste. Waste characteristics defined in system requirements (see Reference 1).

Functional Subclement 10. $\quad$ Packaging

10.1 Technical Background and Assumptions

10.2 Input

10.2.1 Conveyed, exhumed waste. Waste characteristics defined in system requirements (see Reference 1).

10.3 Requirements

10.3.1 The packaging system shall package and label the retricved waste stream to meet all of the RWMC transportation requirements (see footnote e).

10.3.2 The packaging system shall be designed so that a criticality event cannot occur.

10.3.3 The packaging system must be designed to accommodate operations, maintenance, and repair in a beta, gamma, alpha, and hazardous contamination environment.

10.3.4 Equipment shall meet or exceed all state, federal, and DOE nuclear systems standards for explosion proof, fire protection, and suppression.

10.3.5 The packaging system shall operate within the temperature and humidity limits in the containment structure.

10.3.6 The packaging system will be designed such that personncl exposure to radiation will comply with DOE Order 5480.11, "Radiation Protection for Occupational Workers."

10.3.7 The packaging system will be designed such that personnel exposure to hazardous materials will comply with all applicable OSHA standards. 
10.4 Output

10.4.1 Packaged waste which is in an acceptable form for transportation to the treatment facility.

Functional Subelement 11. Transport to Treatment

11.1 Technical Background and Assumptions

11.1.1 The retrieval system can be co-located with the treatment facility.

11.2 Input

11.2.1 Waste which is in acceptable form for transportation to treatment.

11.3 Requirements

11.3.1 Meet RWMC transportation requirements (see footnote e).

11.3.2 The transport system shall be designed so that a criticality event cannot occur.

11.4 Output

11.4.1 Packaged waste delivered to the waste treatment facility receiving subelement.

Functional Subclement 12. Treatment Facility General Requirements

12.1 Technical Background and Assumptions

12.1.1 The treatment facility has a classification of Moderate Hazard per UCRL-15910 (sec Reference 9).

12.1.2 The entire thermal processing line can be designed, constructed, and tested to maintain alpha contamination controls.

12.1.3 The treatment facility shall meet requirements set forth in Nuclear Safety Analysis Reports (DOE Order 5480.23).

12.2 Input

Not applicable

12.3 Requirements

12.3.1 A minimum of double confinement per DOE Order 6430.1 A shall exist between normally contaminated areas and uncontrolled areas. 
12.3.2 Equipment designs and interfaces shall be designed to maintain alpha, beta, and gamma contamination confinement.

12.3.3 All systems in the treatment facility shall be designed so that a criticality event cannot occur. The treatment facility will follow criticality control requirements per DOE Order $5480.5^{13}$ and DOE-ID Order $5480.5 \mathrm{~A}^{14}$

12.3.4 These systems shall meet or exceed all state, federal, and DOE nuclear systems standards for explosion proof, fire protection, and suppression.

12.3.5 All systems in the treatment facility will be designed such that personnel exposure to radiation will comply with DOE Order 5480.11, "Radiation Protection for Occupational Workers."

12.3.6 All systems in the treatment facility will be designed such that personnel cxposure to hazardous materials will comply with all applicable OSHA standards.

12.3.7 The overall treatment facility and operational systems shall meet the requirements for a Radioactive Solid Waste Facility per DOE Order 64.30.1A, Section 1.324 (see Reference 10).

12.3.8 Additional high-level requirements are contained in Reference 15.

12.4 Output

Not applicable

\section{Functional Subelement 13. Treatment Facility Receiving}

\subsection{Technical Background and Assumptions}

13.1.1 The receiving subelement performs the functions of accepting transported material supplied by the transport-for-treatment subelement. Temporary storage for queuing may or may not be a required function, and is dependent upon the specific technologics comprising the technology process options.

13.2 Input

Packaged waste delivered to the treatment facility.

13.3 Requirements

13.3.1 Receive waste from transportation system and store until conveyance is ready to accept waste. 
13.4 Output

13.4.1

Waste delivered to the treatment waste conveyance system.

Functional Subclement 14. Treatment Waste Conveyance

14.1 Technical Background and Assumptions

14.1.1 The conveyance functional subelement includes all apparatus to convey the retrieved waste or removed overburden within the treatment containment structure.

14.2 Input

14.2.1 Packaged waste delivered to the treatment waste conveyance.

14.3 Requirements

14.3.1 The waste conveyance system must be designed to accommodate operations, maintenance, and repair in a beta, gamma, alpha, and hazardous contamination environment.

14.3.2 The conveyance system shall operate within the temperature and humidity limits in the containment structure.

14.3.3 The conveyance subelement must be able to convey all the various forms of wastes within the treatment facility.

14.3.4 The conveyance subelement must convey necessary process feedstocks and process by-products.

14.3.5 Waste conveyance shall not change waste characteristics.

14.4 Output

Packaged containers containing quantities of soil and waste. The waste consists of combustibles and noncombustibles contaminated with organics, radionuclides, and heavy metals. Specifics on expected waste types and their contaminants can be found in the BWID System Analysis System Requirements (see Reference 1).

Functional Subelement 15. $\quad$ Size Reduction

15.1 Technical Background and Assumptions

15.1.1 Much effort has been spent on characterization of the RWMC buried waste. Because of less stringent disposal methods, a large degree of inaccuracy must be assumed for any published numbers. The thermal treatment secnarios consider the waste input stream to contain these waste categorics plus contaminated soil in varying amounts and percentages. 
15.1.2 It is assumed that transportation containers will become part of the waste stream, and thus must be size reduced.

\subsection{Input}

Packaged containers containing quantities of soil and waste. The waste consists of combustibles and noncombustibles contaminated with organics, radionuclides, and heavy metals. Specifics on expected waste types and their contaminants can be found in BWID Systems Analysis System Requirements (see Reference 1).

15.3 Requirements

Process must be capable of reducing size of packaged waste to meet size requirements of downstream treatment process.

15.4 Output

Size-reduced waste stream.

Functional Subclement 16. Pre-Treatment Characterization

16.1 Technical Background and Assumptions

16.2 Input

16.2.1 Size-reduced waste stream.

16.3 Requirements

16.3.1 Monitor for gross volatile organic compounds (VOCs) identified in BWID System Analysis System Requirements (see Reference 1) to assist in melter performance and maintain safe operations.

16.3.2 Monitor for gross radionuclides identified in BWID System Analysis System Requirements (see Reference 1) and radiation levels to assist in process safety controls and quality control of the final waste form.

16.3.3 Monitor as necessary for other gross concentrations of constituents which are difficult to process such as chlorides, High Vapor Pressure Metals (HVPMs), and sulfur. The constituents which are difficult to process are determined by the melting technology chosen.

16.3.4 Data acquisition is compatible with down stream processes.

16.4 Output

16.4 .1

Entire waste stream not changed from input. 

difficult to process.

Functional Subelement 17. Metals Sort

17.1 Technical Background and Assumptions

17.1.1 It is assumed that atypical waste is not included in the main waste stream.

17.2 Input

Reduced waste stream from the pretreatment characterization and size reduction subelements.

17.3 Requirements

17.3.1 Sort metals from the waste stream.

17.3.2 Bulk processing rate necessary to be compatible with interfacing subelements.

17.4 Output

17.4.1 Waste stream less sorted metals (combustibles, noncombustibles, soil, organics, and residual metals from inefficient sorting).

Waste stream of metals only and residual soil and organics from inefficient sort.

Functional Subelement $18 . \quad$ Thermal Desorber

18.1 Technical Background and Assumptions

18.1.1 The thermal desorber functional subelement disassociates nitrate compounds that could cause combustible pulsing of the incinerator. The thermal desorber operating temperature is based on a temperature which is high enough for initial thermal decomposition of nitrates (potassium nitrate decomposes at $400^{\circ} \mathrm{C}$, and sodium nitrate decomposes at $380^{\circ} \mathrm{C}$ ).

18.2 Input

18.2 .1

A size-reduced waste stream consisting of combustibles, noncombustibles, soil, organics, plus some residuals metals.

18.2.2 Offgas from the High Temperature Oxidizing Slag, Oxidizing Metal/Metal Tapping Melter. 
18.3 Requirements

18.3.1 Heat all waste stream constituents to a temperature of TBD degrees centigrade.

18.3.2 Hold preheated waste stream constituents at a temperature of TBD degrees for a time of TBD minutes.

18.3.3 Meet input requirements of downstream processes.

18.3.4 Process main waste stream at system throughput rate.

18.4 Output

18.4.1 Preheated non-metallic waste stream.

18.4.2 Offgas.

Functional Subelement 19. Incinerator

19.1 Technical Background and Assumptions

19.1.1 Incineration/pyrolysis of the waste stream is performed to combust the majority of the combustible portion (including organics) of the waste stream. Low temperature incineration may be preferred for reduction in corrosion and erosion of the incinerator. This also may result in reduction in plugging potential of the ash and residuals in the material handling system.

19.1.2 It is also very desirable to adopt a design that will produce a minimum offgas flow rate. This will simplify any necessary offgas treatment system.

19.2 Input

19.2.1 Preheated non-metallic waste stream.

19.2.2 Offgas from the Thermal Desorber subelement.

19.3 Requirements

19.3.1 Incineration/pyrolysis of the waste stream.

19.3.2 Meet downstream input requirements and system throughput processing rate.

19.4 Output

19.4.1 Pyrolized ash.

19.4.2 A combusted offgas stream plus minor products of incomplete combustion. 
Functional Subelement 20. $\quad$ Alterburner

20.1 Technical Background and Assumptions

20.1.1 The output stream from the afterburner is assumed to contain $\mathrm{H}_{2} \mathrm{O}, \mathrm{CO}_{2}$, ano High Vapor Pressure Metals (HVPMs such as mercury, lead, cadmium, arsenic, etc.), HVPM oxides, halogens, sulfur compounds, combusted organics, particulates, and some radionuclides ( $\mathrm{Cs}^{137}$, potential minor quantities of TRU oxides, and other LLW radionuclides).

20.1.2 One possible design will maintain the offgas stream for a minimum time at a minimum temperature (approximately $>2 \mathrm{sec}$ at $>1010^{\circ} \mathrm{C}$ ) to ensure complete combustion.

20.2 Input

2().2.1

A combusted offgas stream plus minor products of incomplete combustion from the incinerator.

20.3 Requirements

20.3.1 The afterburner shall ensure 99.9999 percent $\left(1\right.$ part in $10^{6}$ ) combustion of all organics in the offgas stream.

20.4 Output

20.4 .1

Combusted offgas stream.

Functional Subelement 21. Mixer

21.1 Technical Background and Assumptions

21.2 Input

21.2.1 Metals (plus residuals) from the metals sort subelement.

21.2.2 Pyrolized ash from the incincrator.

21.2.3 Flux if required for melter process control.

21.2.4 Basaltic soil (contaminated overburden soil) as needed for melter process control and final waste form quality control.

21.3 Requirements

21.3.1 Mix and blend feedstock. 


\subsection{Output}

Blended feedstock to the melter.

Functional Subelement 22. Oxidizing Slag, Oxidizing Metal/Metal Tapping Melter

\subsection{Technical Background and Assumptions}

22.1.1 The composition of the molten slag output stream is assumed to be an ironenriched basalt matrix with dissolved metal oxides, and TRU plus LLW contaminants. This assumption is based on work as reported in References 16, 17, 18 , and 19.

22.1 .2

The offgas stream from the high temperature melter is assumed to potentially contain $\mathrm{H}_{2} \mathrm{O}, \mathrm{CO}_{2}$, and High Vapor Pressure Metals (HVPMs such as mercury, lead, cadmium, arsenic, etc.), HVPM oxides, halogens, sulfur compounds, combusted organics, particulates, and some radionuclides $\left(\mathrm{Cs}^{137}\right.$. potential minor quantities of TRU oxides, and other LLW radionuclides).

22.1.3 The metals contained in the molten metal output stream are assumed to be mainly iron (Fe) with trace other metals included.

22.2 Input

Blended feedstock from the mixer consisting of metals plus residuals from the metals sort subelement, ash plus soil plus residuals from the incinerator, flux as required for melter process control, and soil as needed for melter process control and final waste form quality control.

22.2 .2

Oxygen gas.

22.3 Requirements

22.3.1 Meet input requirements of downstream subelements.

22.3.2 Operating temperature high enough to melt metals and melt the basaltic soils maintaining an adequate viscosity for the Homogeneous slag Frit/Monolith subelement.

22.3.3 The melter output shall contain none of the organic constituents found in the system requirements (see Reference 1 ).

22.3.4 Produce a waste form that is no longer considered a hazardous waste per 4)CFR261. 
22.4 Output

22.4.1 An offgas waste stream to the thermal desorber/incinerator or afterburner.

22.4.2 Molten slag to the slag handling subsystem.

22.4.3 Tapped molten metals to the molten metals subsystem.

Functional Subelement 23. Homogeneous Slag Frit/Monolith

23.1 Technical Background and Assumptions

23.1.1 The composition of the molten slag output stream is assumed to be an iron-enriched basalt matrix with dissolved metal oxides, and TRU plus LLW contaminants. This assumption is based on experimental and calculated work as reported in References $16,17,18$, and 19 .

23.1.2 The output of the melter is assumed to be slag frit or monolith, whichever form enables a high quality, high reliability radioactive assay.

23.2 Input

Tapped molten slag from the melter.

23.3 Requirements

23.3.1 Receive and handle the molten slag from the melter, and cast it into monoliths or process into a frit form.

The waste form will prevent the release of radionuclides and heavy metals.

\subsection{Output}

23.4.1

Slag in the form of a frit or monolith compatible with downstream processes.

Functional Subelement 24. Tapped Metal

24.1 Technical Background and Assumptions

24.1.1 No radionuclides, or only very minor quantities of radionuclides, are expected to be partitioned into the molten metals stream. The radionuclides are expected to be partitioned into the slag, with potentially some carryover into the offgas system. However, radiological controls must still be emplaced on the metals stream.

24.1.2 The metals contained in the molten metal output stream are assumed to be mainly iron (Fe) with trace other metals included. 
24.1.3 A high reliahility assay of the metals is assumed to be possible in the monolith form.

24.2 Input

24.2.1 Molten metal tapped from the melter.

24.3 Requirements

24.3.1 Receive and handle the molten metal from the melter and cast into monolith forms.

24.3.2 Produce a waste form that is no longer considered a hazardous waste per 40CFR261.

\subsection{Output}

A metal monolith waste form.

Functional Subelement 25. Offgas Treatment

25.1 Technical Background and Assumptions

25.1.1 The offgas stream to the offgas treatment system is assumed to contain $\mathrm{H}_{2} \mathrm{O}, \mathrm{CO}_{2}$, High Vapor Pressure Metals (HVPMs) (mercury, lcad, cadmium, arscnic, etc.), HVPM oxides, halogens, sulfur compounds, combusted organics, particulates, and some radionuclides ( $\mathrm{Cs}^{137}$, potential minor quantities of TRU oxides, and other LLW radionuclides).

25.1.2 The offgas unabated relcase calculations are assumed to confirm the potential for discharge of radionuclides resuiting in effective dose equivalents greater than allowable per 40CFR61.92.

25.2 Inpul

Offgas stream from the thermal treatment processes.

25.3 Requirements

25.3.1

The offgas treatment system shall clean the offgas stream of all constituents to allow operations within applicable State and Federal air permit requirements.

Per DOE 6430.1a, 40CFR60, 40CFR61, and ANSI N13.1. the offigas treatment system shall be equipped with air monitoring instruments to detect radionuclides and hazardous constituents listed in the BWID Systems Analysis System Requirements (see Reference 1). The final released offgas effluent shall be monitored for any normally or accidentally released radionuclides via an isokinetic sampling system. 
25.3.3 The offgas system must be maintained at a sufficient negative pressure to draw all gaseous flows through the systems and still maintain adequate negative pressure at the most remote location.

\subsection{Output}

25.4.1 A cleaned offgas gaseous waste stream which meets all appropriate permit requirements.

25.4.2 One or more offgas residue streams.

25.4.3 Process waste stream specific to the offgas treatment chosen.

Functional Subelement 25A. Zero Emissions Offgas Treatment

(Optional)

25A.1 Technical Background and Assumptions

25A.1.1 The offgas stream to the offgas treatment system is assumed to contain $\mathrm{H}_{2} \mathrm{O}, \mathrm{CO}_{2}$, and High Vapor Pressure Metals (HVPMs) (such as mercury, lead, cadmium, arsenic, etc.), HVPM oxides, halogens, sulfur compounds, combusted organics, particulates, and some radionuclides ( $\mathrm{Cs}^{137}$, potential minor quantities of TRU oxides, and other LLW radionuclides).

25A.1.2 Requirements for this type of offgas system are considered to exceed the requirements necessary to meet present day permitting applications. However, permitting actions are assumed to be greatly enhanced with stricter requirements due to the decreased nature of offgas emissions.

25A.1.3 Zero emissions offgas systems of this type are assumed to be only in the research and development stage. Proven technology is assumed to be nonexistent. A large development effort is assumed to be required for this option.

25A.2 Input

25A.2.2 Offgas stream from the thermal treatment processes.

25A.3 Requirements

25A.3.1 The zern emissions offgas treatment system option shall clean the offgas stream of all constituents with the exception of a minor stream of inert gas. NOTE: These restrictions surpass the present permit requirements for operations. Any minor remaining offgas stream must include full high efficiency particulate air (HEPA) filtering of the stream. 
25A.3.2 This option for offgas treatment must convert all offgas constituents 10 solid or liquid form for further disposition.

25A.4 Output

25A.4.1 Potential offgas stream consisting of inert gas.

25A.4.2 An offgas residue stream in liquid or solid form.

Functional Subclement 26. $\quad \underline{\text { Mixer }}$

26.1 Technical Background and Assumptions

26.2 Input

26.2.1 Residue from the offgas treatment subsystem.

26.2.2 Borosilicate glass (BSG) frit.

26.3 Requirements

26.3.1 Mixes and blends feedstock to meet melter input requirements.

26.4 Output

26.4.1 Blended BSG and residue feedstock to the melter.

Functional Subelement $27 . \quad$ Offgas Residue Melter

27.1 Technical Background and Assumptions

27.1.1 Assumed melter temperature is a nominal $1100^{\circ} \mathrm{C}$ based on operating temperatures for melters designed for vitrification of high-level waste (HLW) using borosilicate glass.

27.2 Input

27.2.1 Blended feedstock from the mixer subelement consisting of residuc from the offgas system and BSG frit.

27.3 Requirements

27.3.1 Operating temperature high enough to melt the BSG frit and the residuc, yet low enough to hold the contaminants (high vapor pressure metals, metal oxides, radionuclides, etc.) in solution.

27.3.2 The output must be compatible with downstream processes. 
Produce a waste form that is no longer considered a hazardous waste per 40CFR261.

27.4 Output

27.4.1

Molten slag

27.4.2

Offgas effluent.

Functional Subelement 28. Offgas Frit/Monolith

28.1 Technical Background and Assumptions

28.1 The composition of the molten slag output stream is assumed to be a borosilicate glass (BSG) matrix with dissolved metal oxides, and potentially very minor quantities of TRU plus LLW contaminants.

28.2 Input

28.2.1 Molten slag from the offgas residue melter subelement.

28.3 Requirements

28.3.1

Receive and handle the molten slag from the melter, and cast it into monoliths or process into a frit form.

28.3.2 Output is compatible with downstream processes

28.4 Output

28.4.1 Homogeneous BSG slag in the form of a frit or monolith.

Functional Subelement 29. Post-Treatment Radioactive Assay

29.1 Technical Background and Assumptions

29.1.1 Assume that pretreatment characterization will not satisfy the requirements for classifying output waste form.

29.1.2 An advantage for thermally processing this type of waste is to convert the asreceived waste stream into a form which will enhance the ability to obtain TRU concentration data with reduced uncertainty.

29.1.3 The bases for this reduction in uncertainty of assay data are:

- The geometry of the assay form can be optimized for the assay equipment (geometry of choice enables consistent geometrical calibration factors). 
- Vitrification and homogenization climinate density variances.

- Vitrification and homogenization eliminate radionuclide distribution variances (fully dissolved radionuclides and complete mixing).

- Vitrification and homogenization enhance the predictability of self shielding (alpha) unknowns.

- Vitrification and geometry of choice allow for reduced assay time due to assay of a known form with decreased variances and enables assay data to be collected at a waste throughput rate of tons per day.

- Vitrification and enhanced assay capability allow for post-treatment sort of TRU waste and LLW based on reliable and consistent assay data.

- Vitrification and enhanced assay capability increases the ability to identify radionuclides and to quantify concentrations of the radionuclides. This enhanced capability increases the credibility of the data and allows for further rational disposition decisions.

\subsection{Input}

29.2.1

Homogeneous IEB or BSG frit or monolith from the thermal treatment subsystems (BSG from offgas stream or IEB from the waste stream).

\subsection{Requirements}

29.3.1 Identify and quantify radionuclides to meet the assay requirements necessary to assign waste as LLW, reclassificd LLW, or transuranic as follows:

- $\quad$ TRU $>100 \mathrm{nCi} / \mathrm{g}-$ Transuranic Waste

- $10 \mathrm{nCi} / \mathrm{g}<\mathrm{TRU}<100 \mathrm{nCi} / \mathrm{g}$ - Reclassified LLW

- $T R U<10 \mathrm{nCi} / \mathrm{g}-\mathrm{LLW}$

29.4 Output

29.4.1

Radioactive assay data.

29.4.2

An unchanged frit or monolith waste form.

Functional Subelement 30. $\quad$ Post-Treatment Medium Temperature Fusing/Re-melt

30.1 Technical Background and Assumptions

30.1.1 This subsystem may be unnecessary if a monolith is cast during initial thermal treatment. The output of frit or monolith from the primary thermal treatment 
subsystem is dependant on the physical form required to enhanec the assay capabilities and produce lower uncertainty reliability assay data.

30.2 Input

30.2.1 Frit or monolith waste from the assay subsystem with TRU $>100 \mathrm{nCi} / \mathrm{g}$.

30.3 Requirements

30.3.1 Fuse or re-melt the IEB frit and cast it into a monolith. (Medium temperature melter operating at a nominal $1400^{\circ} \mathrm{C}$.)

30.4 Output

30.4 .1

A monolithic IEB waste form.

Functional Subclement 31. $\quad$ Heat Treat/Controlled Cool

31.1 Technical Background and Assumptions

31.1.1 The purpose of this functional subelement is to change the microstructure of the cast monolith waste form such that the resulting waste form has low leach rate and high durability.

31.1.2 This subelement along with the fusing/re-melt subelement may be unnecessary functions if assay systems are identified that can provide high quality, reliable data from a monolith cast block direct from the primary thermal process subelement.

31.2 Input

31.2.1 The input for this subelement is a monolith waste form either direct from the primary thermal process subsy tem via the assay subsystem or from the fusing/re-melt melter subelement.

\subsection{Requirements}

31.3.1 Control cooling to optimize the microstructure in order to meet leach rate and durability requirements.

31.3.2 The subsystem shall include nondestructive test capabilities to verify the integrity of the final waste form.

31.4 Output

31.4.1 Iron-enriched basalt (IEB) monolith waste form. 
Functional Subelement 32. TRU Waste Packaging

32.1 Technical Background and Assumptions

32.1.1 The designated disposition is for interim storage at the INEL pending resolution and opening of a permanent repository for TRU/TRU-Mixed buried waste.

32.2 Input

32.2 .1

Monolithic waste forms with concentration of TRU $>100 \mathrm{nCi} / \mathrm{g}$.

32.3 Requirements

32.3 .1

Packaging requirements shall meet current INEL TRU Waste Acceptance Criteria (see Reference 7), and RWMC transportation requirements (see footnote e).

32.4 Output

32.4 .1

Packaged TRU > $100 \mathrm{nCi} / \mathrm{g}$ waste.

Functional Subelement 3.3. Final Package Assay

33.1 Technical Background and Assumptions

33.2 Input

33.2 .1

Packaged TRU > $100 \mathrm{nCi} / \mathrm{g}$ waste.

33.3 Requirements

33.3.1 Final assay and external contamination swipe surveys for INEL TRU Waste Acceptance Criteria.

33.4 Output

33.4.1 Packaged TRU $>100 \mathrm{nCi} / \mathrm{g}$ waste.

Functional Subelement 34. Transportation

34.1 Technical Background and Assumptions

34.1.1 Transportation to interim storage can occur within the RWMC and thus will not have to fully comply with the EG\&G Hazardous Material Transportation Manual (see footnote f). 
34.2 Input

34.2.1 Waste which is in an acceptable form for transportation to and storage in interim storage.

\subsection{Requirements}

34.3.1 RWMC transportation requirements (see footnote e).

34.4 Output

34.4.1 Packaged waste and its associated assay information delivered to interim storage facilities.

Functional Subelement 35. INEL TRU Interim Storage

35.1 Technical Background and Assumptions

35.2 Input

35.2.1 Packaged TRU $>100 \mathrm{nCi} / \mathrm{g}$ waste.

35.3 Requirements

35.3.1 Retrievable storage at the INEL.

35.4 Output

35.4.1 Packaged TRU $>100 \mathrm{nCi} / \mathrm{g}$ waste.

Functional Subelement 36. $\quad$ Reclassified Low-Level Waste Packaging

36.1 Technical Background and Assumptions

36.1.1 Assume reclassified LLW has same INEL WAC as LLW.

36.2 Input

36.2.1 Reclassified LLW waste in a frit or monolith form with a concentration of $10 \mathrm{nCi} / \mathrm{g}<\mathrm{TRU}<100 \mathrm{nCi} / \mathrm{g}$.

36.3 Requirements

36.3.1 Packaging shall be per INEL LLW Waste Acceptance Criteria (see Reference 6).

36.3.2 Disposal shall be per INEL LLW disposal criteria (see Reference 6). 
36.4 Output

36.4.1 Packaged $10 \mathrm{nCi} / \mathrm{g}<\mathrm{TRU}<100 \mathrm{nCi} / \mathrm{g}$ waste in an approved container.

Functional Subelement 37. Low-Level Waste Packaging INEL Disposal

37.1 Technical Background and Assumptions

37.1.1 The waste derived from fixing the offgas residue into borosilicate glass is assumed to be LLW. The potential for TRU elements to be carried off into the offgas waste stream is considered to be very small. Classification as LLW is verified in the assay subelement (50.0).

37.2 Input

37.2.1 Low-level waste in a borosilicate glass frit or monolith form.

37.3 Requirements

37.3.1 Packaging shall be per INEL LLW Waste Acceptance Criteria (see Reference 6).

37.4 Output

37.4 .1

Packaged LLW. 


\section{Option C \\ Retrieval/Incineration/Melter Treatment}

\section{Functional Subclement 1. Site/Waste Characterization}

\subsection{Background Technical Information and Assumptions}

1.1.1 The waste pits were excavated to the underlying basalt layer and generally backfilled with 2 to $5 \mathrm{ft}$ of soil to provide a level floor. The waste trenches were generally excavated to the hasalt layer, approximately $10 \mathrm{ft}$ down and averaged about $7 \mathrm{ft}$ wide and up to $1800 \mathrm{ft}$ long (see Reference 4). Following excavation, wastes were placed into the pits and trenches. From 1952-1963, the waste containers were stacked to optimize disposal space. During 1963-1969, the waste packages were randomly dumped into the pits and trenches in order to limit worker radiation exposure. In 1969 , the waste containers were once again stacked to optimize disposal volume. Once emplaced, the wastes were backfilled with and covered with silty clay and sandy soil.

1.1.2 Physical dimensions of each waste pit and trench (including overburden) are given in Tables 1, 2, and 3 of Reference 4. Details of the charactcristics of INEL RWMC soils are given in Tables 4 through 8 of Reference 4 (sec Appendix A).

1.1.3 Figure 7 illustrates a cross-section of a typical Operable Unit (OU) 7-13 waste pit or trench. The figure identifies terms used throughout this report.

\subsection{Input}

Transuranic (TRU)-Contaminated Waste Pits and Trenches located at the INEL Subsurface Disposal Area (designated as Operable Unit 7-13).

\subsection{Requirements}

The following shall be determined during site/waste characterization:

1.3.1 Vertical boundaries of the waste pits and trenches.

1.3.2 Depth of the basalt underlying the waste pits and trenches.

1.3.3 Depth of the overburden/waste interface for each waste pit and trench.

1.3.4 Location of any outsize waste in the waste scam.

\subsection{Output}

Estimated boundaries of TRU-Contaminated Waste Pits and Trenches. 
Functional Subelement $2 . \quad$ Below-Grade Isolation

\subsection{Background Technical Information and Assumptions}

2.1.1 The basalt is assumed to offer below-grade horizontal isolation of the waste.

2.1.2 The concern of leakage through the barriers is mitigated by INEL RWMC site renovations performed under the 300-yr Flood Drainage Program.

2.1.3 The subsurface basalt is at a depth that is less than $30 \mathrm{ft}$ for any given waste pit or trench.

2.1.4 The defined waste seam will be established by an institutional review of the estimated boundaries (see Figure 8). Establishment of the defined waste seam will be performed by institutional entities. This group will be expected to identify the defined waste seam boundary for each pit or trench that includes some margin in addition to the estimated boundary values.

\subsection{Input}

2.2.1 Estimated boundaries of TRU-Contaminated Waste Pits and Trenches.

\subsection{Requirements}

2.3.1 Construct engineered barriers extending vertically from the surface to the basalt at the location of the defined waste seam to provide below-grade isolation of the volume to be remediated.

The engineered barriers shall be designed to meet or exceed all the applicable federal, state, and DOE structural safety standards for mining or excavations.

\subsection{Output}

Below-grade isolation barriers which define the volume of waste to be remediated.

\section{Functional Subelement 3. Ahove-Grade Containment}

\subsection{Background Technical Information and Assumptions}

3.1.1 The entire above-grade containment shall have a facility classification of moderate hazard per UCRL-15910 (see Reference 9).

\subsection{Input}

3.2.1 Below-grade isolation barriers of the volume to be remediated.

\subsection{Requirements}

3.3.1 The above-grade containment structure(s) must encompass the entire volume currently being excavated. 
3.3.2 The above-grade containment structure(s) shall be designed and constructed to meet the following applicable INEL building standards: Gencral Design Criteria (DOE 64.30.1A), ${ }^{10}$ Natural Phenomenon (UCRL-15910), ${ }^{9}$ DOE-ID Architectural Engincering Standards, ${ }^{11}$ Operational Safety Design Criteria Manual, ${ }^{12}$ Industry Standard Uniform Building Code (UBC), and Nuclear Safety Analysis Report (DOE Order 5480.23)

\section{3 .3}

The above-grade containment structure(s) shall have the following features:

3.3.3.1

Shall be designed to control contamination from radiological and non-radiological sources to allow maintenance repair or replacement of systems.

3.3.3.2 Shall be designed to allow all necessary activities to support ancillary activities conducted within the containment structure such as retrieval, package, and transport of excavated waste.

3.3.3.3 Shall be designed to allow ingress/egress of all equipment and personnel necessary to perform all waste retrieval activities.

3.3.3.4 Shall be designed to allow the egress of retricved waste packaged for transfort.

3.3.3.5 Shall have temperature and humidity control such that the environment is regulated within the limits required for maintenance repair or replacement activities in a beta, gamma, alpha, and hazardous contaminated environment.

3.3.4 The above-grade containment structure shall contain all operations from overburden retricval to transport to interim storage/treatment.

\subsection{Output}

3.4.1 Completed and operational containment facility over the isolated region being excavated.

Functional Subelement $4 . \quad$ Overburden Characterization

\subsection{Background Technical Information and Assumptions}

4.1.1 Prior to any removal of overburden, an extensive characterization of the overburden will be performed.

4.1.2 Data from underburden characterization activities will meet data quality objectives and be useable for risk assessments.

\subsection{Input}

4.2.1 Completed and operational containment facility over the isolated region being excavated. 


\subsection{Requirements}

4.3.1 The characterization will locate any regions of contamination within the pit or trench overburden.

4.3.2 Characterization techniques must be able to sample for radioactive, including TRU, and characteristic and listed hazardous contaminants defined in the BWID Systems Analysis s! iteın :equirements (see Reference 1).

\subsection{Output}

Location and characterization of radioactive and characteristic and listed hazardouscontaminated overburden.

Functional Subclement 5. Overhurden Removal

\subsection{Technical Background and Assumptions}

\subsection{Input}

Location and characterization of radioactive and characteristic and listed hazardouscontaminated overburden.

\subsection{Requirements}

5.3.1 Up to $75 \%$ of the estimated overburden depth for each pit or trench will be removed. Sufficient overburden will be left in place so as to minimize the possibility of an inadvertent contamination exposure.

5.3.2 The removal process will separate contaminated (radioactive and hazardous) from noncontaminated overburden.

5.3.3 Overburden removal operations must control contamination from beta, gamma, alpha, and the hazardous constituents defined in the BWID Systems Analysis system requirements (see Reference 1) to levels that would allow maintenance to service or repair equipments.

5.3.4 These systems shall meet or exceed all state, federal, and DOE nuclear systems standards for explosion proof, fire protection, and suppression.

\subsection{Output}

5.4.1 The completed containment facility over the region to be remediated. Up to $75 \%$ of overburden removed.

5.4.2 Contaminated (radioactive and hazardous) overburden.

5.4.3 Noncontaminated overburden.

Functional Subelement 6. Storage of Contaminated Overburden

6.1 Technical Background and Assumptions 
6.2 Input

6.2.1 Contaminated (radioactive and hazardous) overburden.

\subsection{Requirements}

6.3.1 Contaminated overburden must he stored within the above-grade containment structure(s).

6.3.2 Contaminated overburden must be physically separated from retrieved noncontarninated and nonassayed overburden.

$6 . .3, \quad$ Stored coritaminated overburden shall not cause a criticality.

6.3.4 Stored contaminated overburden shall have beta, gamma, alpha, and hazardous contamination control compatible with containment requirements of 3.3.3.1.

\subsection{Output}

Stored contaminated overburden.

Functional Subelement 7. Noncontaminated Overburden Storage

7.1 Technical Background and Assumptions

7.2 Input

7.2.1 . Retrieved noncontaminated overburden.

\subsection{Requirements}

7.3.1 Retrieved noncontaminated overburden shall be stored in a weather shielded storage.

7.3.2 If the noncontaminated storage is located outside the containment building then the noncontaminated overburden shall be surveyed to ensure that it is free of beta, gamma, alpha, and hazardous contamination prior to removal from the containiment building.

\subsection{Output}

7.4.1 Stored noncontaminated overburden to be used to refill the remediated pit or trench.

Functional Subelement $8 . \quad$ Retrieval

8.1 Technical Background and Assumptions

8.1.1 The retrieval functional subelement includes all apparatus to remove all remaining overburden and the waste from the ground, control the spread of contamination 
during the removal, and convey the retrieved waste from the dig face to a packaging area for eventual shipment for treatment.

8.1.2 The assumption for this subelement is that criticality can be prevented.

\subsection{Input}

8.2.1 The completed containment facility over the region to be remediated. $75 \%$ of estimated overburden depth removed.

\subsection{Requirements}

8.3.1 The retrieval system shall exhume material within the waste seam and transfer that material to a waste conveyance system.

8.3.2 The retrieval systems shall operate within the temperature and humidity limits inside the containment structure.

8.3.3 The retrieval systems must be designed to accommodate operations, maintenance, and repair in a beta, gamma, alpha, and hazardous contamination environment.

8.3.4 The retrieval system shall be designed such that a criticality cannot occur.

8.3.5 Retrieval operations must identify and accommodate atypical waste objects (objects or material incompatible with the retrieval system) or high radiation sources. Identification may involve characterization at the dig-face. NOTE: An acceptable way to "accommodate atypical waste" objects is that the retrieval system may move these objects and stabilize them in the retrieval pit or other designated area to prevent contamination spread and/or to shield high sources of radiation as stated in system requirements (see Reference 1). Retrieval operations may bypass these stabilized objects and continue normal operations until such time that special case equipments and procedures will allow for their removal.

8.3.6 The retrieval system shall meet or exceed all applicable state, federal, and DOE nuclear systems standards for explosion proof, fire protection, and suppression.

8.3.7 Retrieval operations and waste packaging for conveyance will be designed such that personnel exposure to radiation will comply with DOE Order 5480.11, "Radiation Protection for Occupational Workers."

8.3.8 Retrieval operations and waste packaging for conveyance will be designed such that personnel exposure to hazardous materials will comply with all applicable OSHA standards.

\subsection{Output}

8.4.1 Exhumed waste. Waste characteristics defined in BWID Systems Analysis system requirements (see Reference 1 ). 


\section{Functional Subelement 9. Waste Conveyance}

\subsection{Technical Background and Assumptions}

9.1.1 The conveyance functional subelement includes all apparatus to convey the retrieved waste or removed overburden within the containment structure.

\subsection{Input}

9.2.1 Exhumed waste. Waste characteristics defined in BWID System Analysis system requirements (see Reference 1 ).

\subsection{Requirements}

9.3.1 The waste conveyance system shall be designed so that a criticality event cannot occur.

9.3.2 The waste conveyance system must be designed to accommodate operations, maintenance, and repair in a beta, gamma, alpha, and hazardous contamination environment.

9.3.3 These systems shall meet or exceed all state, federal, and DOE nuclear systems standards for explosion proof, fire protection, and suppression.

9.3.4 The conveyance system shall operate within the temperature and humidity limits in the containment structure.

9.3.5 The conveyance system will be designed such that personnel exposure to radiation will comply with DOE Order 5480.11, "Radiation Protection for Occupational Workers."

9.3.6 The conveyance system will be designed such that personnel exposure to hazardous materials will comply with all applicable OSHA standards.

\subsection{Output}

9.4.1 Conveyed, exhumed waste. Waste characteristics defined in system requirements (see Reference 1).

Functional Subelement 10. $\quad$ Packaging

10.1 Technical Background and Assumptions

10.2 Input

10.2.1 Conveyed, exhumed waste. Waste characteristics defined in system requirements (see Reference 1). 
10.3 Requirements

10.3.1 The packaging system shall package and label the retricved waste stream to meet all of the RWMC transportation requirements (sec footnote e).

10.3.2 The packaging system shall be designed so that a criticality event cannot occur.

10.3.3 The packaging system must be designed to accommodate operations, maintenance, and repair in a beta, gamma, alpha, and hazardous contamination environment.

10.3.4 Equipment shall meet or exceed all state, federal, and DOE nuclear systems standards for explosion proof, fire protection, and suppression.

10.3.5 The packaging system shall operate within the temperature and humidity limits in the containment structure.

10.3.6 The packaging system will he d/ssigned such that personnel exposure to radiation will comply with DOE Order 5480.11, "Radiation Protection for Occupational Workcrs."

10.3.7 The packaging system will be designed such that personnel exposure to hazardous materials will comply with all applicable OSHA standards.

10.4 Output

10.4.1 Packaged waste which is in an acceptable form for transportation to the treatment facility.

Functional Subclement 11. Transport to Treatment

11.1 Technicai Background and Assumptions

11.1.1 The retrieval system can be co-located with the treatment facility.

11.2 Input

11.2.1 Waste which is in acceptable form for transportation to treatment.

11.3 Requirements

11.3.1 Mcet RWMC transportation requirements (see footnote e).

11.3.2 The transport system shall be designed so that a criticality cvent cannot occur.

11.4 Output

11.4.1 Packaged waste delivered to the waste treatment facility receiving subclement. 
Functional Subelement 12. Treatment Facility General Requirements

12.1 Technical Background and Assumptions

12.1.1 The treatment facility has a classification of Moderate Hazard per UCRL-15910 (see Reference 9).

12.1.2 The entire thermal processing line can be designed, constructed, and tested to maintain alpha contamination controls.

12.1.3 The treatment facility shall meet requirements outlined in Nuclear Safety Analysis Reports (DOE Order 5480.23).

12.2 Input

Not applicable

12.3 Requirements

12.3.1 A minimum of double confinement per DOE Order 6430.1A shall exist between normally contaminated areas and uncontrolled areas.

12.3.2 Equipment designs and interfaces shall be designed to maintain alpha, beta, and gamma contamination confinement.

12.3.3 All systems in the treatment facility shall be designed so that a criticality event cannot occur. The treatment facility will follow criticality control requirements per DOE Order $5480.5^{13}$ and DOE-ID Order 5480.5A. ${ }^{14}$

12.3.4 These systems shall meet or exceed all state, federal, and DOE nuclear systems standards for explosion proof, fire protection, and suppression.

12.3.5 All systems in the treatment facility will be designed such that personnel exposure to radiation will comply with DOE Order 5480.11, "Radiation Protection for Occupational Workers."

12.3.6 All systems in the treatment facility will be cesigned such that personnel exposure to hazardous materials will comply with all applicable OSHA standards.

12.3.7 The overall treatment facility and operational systems shall meet the requirements for a Radioactive Solid Waste Facility per DOE Order 6430.1A. Section 1324 (sce Reference 10).

12.3.8 Additional high-level requirements are contained in Reference 15.

12.4 Output

Not applicable 
Functional Subelement 13. Treatment Facility Receiving

\subsection{Technical Background and Assumptions}

13.1.1 The receiving subelement performs the functions of accepting transported material supplied by the transport-for-treatment subelement. Temporary storage for queuing may or inay not be a required function, and is dependent upon the specific technologies comprising the technology process options.

13.2 Input

Packaged waste delivered to the treatment facility.

\subsection{Requirements}

13.3.1 Receive waste from transportation system and store until conveyance is ready to accept waste.

\subsection{Output}

13.4.1 Waste delivered to the treatment waste conveyance system.

Functional Subelement 14. Treaiment Waste Conveyance

14.1 Technical Background and Assumptions

14.1.1 The conveyance functional subelement includes all apparatus to convey the retrieved waste or removed overburden within the treatment containment structure.

14.2 Input

14.2.1 Packaged waste delivered to the treatment waste conveyance.

\section{4:3 Requirements}

14.3.1 The waste conveyance system must be designed to accommodate operations, maintenance, and repair in a beta, gamma, alpha, and hazardous contamination environment.

14.3.2 The conveyance system shall operate within the temperature and humidity limits in the containment structure.

14.3.3 The conveyance subelement must be able to convey all the various forms of wastes within the treatment facility.

14.3.4 The conveyance subelement must convey necessary process feedstocks and process by-products.

14.3.5 Waste conveyance shall not change waste characteristics. 


\subsection{Output}

14.4.1 Packaged containers containing quantities of soil and waste. The waste consists of combustibles and noncombustibles contaminated with organics, radionuclides, and heavy metals. Specifics on expected waste types and their contaminants can be found in the BWID System Analysis System Requirements (see Reference 1).

\section{Functional Subelement $15 . \quad$ Size Reduction}

\subsection{Technical Background and Assumptions}

Much effort has been spent on characterization of the RWMC buried waste. The basis for characterization are from past reports, sampling programs, and other efforts; however, since past practices allowed for much less stringent disposal methods, a large degree of inaccuracy must be assumed for any published numbers. The thermal treatment scenarios consider the waste input stream to contain these waste categories plus contaminated soil in varying amounts and percentages.

15.1.2 It is assumed that transportation containers will become part of the waste stream, and thus must be size reduced.

15.2 Input

Packaged containers containing quantities of soil and waste. The waste consists of combustibles and noncombustibles contaminated with organics, radionuclides, and heavy metals. Specifics on expected waste types and their contaminants can be found in BWID Systems Analysis System Requirements (see Reference 1).

15.3 Requirements

15.3.1 Process must be capable of reducing size of packaged waste to meet size requirements of downstream treatment process.

15.4 Output

15.4 .1

Size-reduced wai te stream.

Functional Subelement 16. Pre-Treatment Characterization

16.1 Technical Background and Assumptions

16.2 Input

16.2.1 Size-reduced waste stream.

16.3 Requirements

16.3.1 Monitor for gross volatile organic compounds (VOCs) identified in BWID System Analysis System Requirements (see Reference 1) to assist in melter performance and maintain safe operations. 
16.3.2 Monitor for gross radionuclides identified in BWID System Analysis System Requirements (see Reference 1) and radiation levels to assist in process safety controls and quality control of the final waste form.

16.3.3 Monitor as necessary for other gross concentrations of constituents which are difficult to process such as chlorides, High Vapor Pressure Metals (HVPMs), and sulfur. The constituents which are diff cult to process are determined by the melting technology chosen.

16.3.4 Data acquisition is compatible with down stream processes.

16.4 Output

16.4.1 Entire waste stream not changed from input.

16.4.2 Data on VOCs, radionuclides, radiation intensity, and other constituents which are difficult to process.

Functional Subelement 17. No Sort

17.1 Technical Background and Assumptions

17.1.1 It is assumed that a minimum amount of soil is a part of the input waste stream for the desired final waste form. This soil comes from TRU and hazardouscontaminated interstitial soil or contaminated underburden soil. The minimum percentage of soil depends on solubility of the different elements which are desired to be bound into the final waste form. The actual minimum percentage number is dependant on specifications for the final form which are not defined (sic) as yet.

17.2 Input

Reduced v'aste stream from the pretreatment characterization and size reduction subelements.

17.3 Requirements

17.3.1 None.

17.4 Output

17.4.1 Size-reduced waste stream.

Functional Subelement $18 . \quad$ Thermal Desorber

18.1 Technical Background and Assumptions

18.1.1 The thermal desorber functional subelement disassociates nitrate compounds that could cause combustible pulsing of the incinerator. The thermal desorber operating temperature is based on a temperature which is high enough for initial thermal 
decomposition of nitrates, (potassium nitrate decomposes at $400^{\circ} \mathrm{C}$, and sodium nitrate decomposes at $380^{\circ} \mathrm{C}$ ).

18.2 Input

18.2.1 Full waste stream.

18.2.2 Offgas from the High Temperature Oxidizing Slag, Oxidizing Metal/Metal Tapping Melter.

18.3 Requirements

18.3.1 Heat all waste stream constituents to a temperature of TBD degrees centigrade.

18.3.2 Hold preheated waste stream constituents at a temperature of TBD degrees for a time of TBD minutes.

18.3.3 Meet input requirements of downstream processes.

18.3.4 Process main waste stream at system throughput rate.

18.4 Output

18.4.1 Preheated waste stream.

18.4.2 Offgas.

Functional Subelement $19 . \quad$ Incinerator

19.1 Technical Background and Assumptions

19.1.1 Incineration/pyrolysis of the waste stream is performed to combust the majority of the combustible portion (including organics) of the waste stream. Low temperature incineration may be preferred for reduction in corrosion and erosion of the incinerator. This also may result in reduction in plugging potential of the ash and residuals in the material handling system.

19.1.2 Note that this option provides for incineration of the full waste stream which consists of combustibles, soil, noncombustibles, and metals. By processing the entire waste stream, it is recognized that the efficiency of incineration may be reduced. However, it may be that the gain realized from maintaining a simplistic design with reduced numbers of subelements outweighs any loss in efficiency. Incinerators can be built very robust and, therefore, the overall thermal process system is not jeopardized by processing noncombustibles and metals in the incinerator. Further, one of the largest driving factors in alpha processing systems is the cost of maintaining alpha controls. To this end, the fewer number of subsystems required, the easier to maintain strict alpha controls.

19.1.3 It is also very desirable to adopt a design that will produce a minimum offgas flow rate. This will simplify any necessary offgas treatment system. 
19.2 Input

19.2.1 Prchcated waste stream.

19.2.2 Offgas from the Thermal Desorber subelement.

19.3 Requirements

19.3.1 Incineration/pyrolysis of the waste stream.

19.3.2 Mect downstream input requirements and system throughput processing rate.

19.4 Output

19.4.1 Pyrolized ash.

19.4.2 A combusted offgas stream plus minor products of incomplete combustion.

Functional Subelement 20. $\quad$ Afterburner

20.1 Technical Background and Assumptions

20.1.1 The output stream from the afterburner is assumed to contain $\mathrm{H}_{2} \mathrm{O}, \mathrm{CO}_{2}, \mathrm{High}$ Vapor Pressure Metals (HVPMs) (such as mercury, lead, cadmium, arsenic, etc.), HVPM oxides, halogens, sulfur compounds, combusted organics, particulates, and some radionuclides $\left(\mathrm{Cs}^{137}\right.$, potential minor quantities of TRU oxides, and other LLW radionuclides).

20.1.2 One possible design will maintain the offgas stream for a minimum time at a minimum temperature (approximately $>2 \mathrm{sec}$ at $>1010^{\circ} \mathrm{C}$ ) to ensure complete combustion.

20.2 Input

20.2.1 A combusted offgas stream plus minor products of incomplete combustion from the incinerator.

20.3 Requircments

20.3.1 The afterburner shall ensure 99.9999 percent $\left(1\right.$ part in $\left.10^{6}\right)$ combustion of all organics in the offgas stream.

20.4 Output

20.4.1 Combusted offgas stream.

Functional Subelement 21. Mixer

21.1 Technical Background and Assumptions 
21.2.1 Pyrolized ash from the incinerator.

21.2.2 Flux if required for melter process control.

21.2.3 Basaltic soil as needed for melter process control and final waste form $c_{1}$ lality control.

\subsection{Requirements}

\subsubsection{Mix and blend feedstock.}

\subsection{Output}

21.4.1 Blended feedstock to the melter.

Functional Subelement 22. Oxidizing Slag, Oxidizing Metal/Metal Tapping Melter

22.1 Technical Background and Assumptions

22.1.1 The output stream from the melter is assumed to potentially contain $\mathrm{H}_{2} \mathrm{O}, \mathrm{CO}_{2}$, High Vapor Pressure Metals (HVPMs) (such as mercury, lead, cadmium, arsenic, etc.), HVPM oxides, halogens, sulfur compounds, combusted organics, particulates, and some radionuclides ( $\mathrm{Cs}^{137}$, potential minor quantities of TRU oxides, and other LLW radionuclides).

22.1.2 The composition of the molten slag output stream is assumed to be an iron-enriched basalt matrix with dissolved metal oxides, and TRU plus LLW contaminants. This assumption is based on work as reported in References 16, 17, 18, and 19.

22.1.3 The metals contained in the molten metal output stream are assumed to be mainly iron $(\mathrm{Fe})$ with trace other metals included.

22.2 Input

22.2.1 Blended feedstock from the mixer consisting of metals, ash, soil and residuals from the incinerator, flux as required for melter process control, and soil as needed for melter process control and final waste form quality control.

22.2 .2

Oxygen gas.

22.3 Requirements

22.3.1 System throughput processing rate.

22.3.2 Operating temperature high enough to melt metals and meit the basaltic soils maintaining an adequate viscosity for the Homogeneous IEB slag Frit/Monolith subelement. 
22.3.3 The melter output shall contain none of the organic constituents listed in the system requirements (see Reference 1 ).

22.3.4 Produce a waste form that is no longer considered a hazardous waste per 40CFR261.

22.4 Output

22.4.1 An offgas waste stream to the thermal desorber/incinerator or afterburner.

22.4.2 Molten slag to the slag handling subsystem.

22.4.3 Tapped molten metals to the tapped metal subelement.

Functional Subelement 23. Homogeneous Slag Frit/Monolith

23.1 Technical Background and Assumptions

23.1.1 The composition of the molten slag output stream is assumed to be an iron-enriched basalt matrix with dissolved metal oxides, and TRU plus LLW contaminants. This assumption is based on experimental and calculated work as reported in References 16, 17, 18, and 19.

23.1.2 The output of the melter is assumed to be slag frit or monolith, whichever form enables a high quality, high reliability radioactive assay.

23.2 Input

23.2.1 Tapped molten slag from the melter.

23.3 Requirements

23.3.1 Receive and handle the molten slag from the melter, and cast it into monoliths or process into a frit form.

23.3.2 The waste form matrix will prevent the release of radionuclides and heavy metals.

23.4 Output

23.4.1 Slag in the form of a frit or monolith compatible with downstream processes.

Functional Subelement 24. Tapped Metal

24.1 Technical Background and Assumptions

24.1.1 No radionuclides, or only very minor quantities of radionuclides, are expected to be partitioned into the molten metals stream. The radionuclides are expected to be partitioned into the slag. with potentially some carryover into the offgas system. However, radiological controls must still be emplaced on the metals stream. 
24.1.2 The metals contained in the molten metal output stream are assumed to be mainly iron $(\mathrm{Fe})$ with trace other metals included.

24.1.3 A high reliability assay of the metals is assumed to be possible in the monolith form.

24.2 Input

24.2.1 Molten metal tapped from the melter.

24.3 Requirements

24.3.1 Receive and handle the molten metal from the melter and cast into monolith forms.

24.3.2 Produce a waste form that is no longer considered a hazardous waste per 40CFR261.

\subsection{Output}

24.4.1 A metal monolith waste form.

Functional Subelement 25. Offgas Treatment

25.1 Technical Background and Assumptions

25.1.1 The offgas stream to the offgas treatment system is assumed to contain $\mathrm{H}_{2} \mathrm{O}, \mathrm{CO}_{2}$, High Vapor Pressure Metals (HVPMs) (such as mercury, lead, cadmium, arsenic, etc.), HVPM oxides, halogens, sulfur compounds, combusted organics, particulates, and some radionuclides ( $\mathrm{Cs}^{137}$, potential minor quantities of TRU oxides, and other LLW radionuclides).

25.1.2 The offgas unabated release calculations are assumed to confirm the potential for discharge of radionuclides resulting in effective dose equivalents greater than allowable per 40CFR61.92.

25.2 Input

25.2 .1

Offgas stream from the thermal treatment processes.

25.3 Requirements

25.3.1 The offgas treatment system shall clean the offgas stream of all constituents to allow operations within applicable State and Federal air permit requirements.

25.3.2

Per DOE 6430.1A, 40CFR60, 40CFR61, and ANSI N13.1, the offgas treatment system shall be equipped with air monitoring instruments to detect radionuclides and hazardous constituents listed in the System Requirements (see Reference 1). The final released offgas effluent shall be monitored for any normally or accidentally released radionuclides via an isokinetic sampling system. 
The offgas system must be maintained at a sufficient negative pressure to draw all gaseous flows through the systems and still maintain adequate negative pressure at the most remote location.

25.4 Output

25.4.1 A cleaned offgas gaseous waste stream which meets all appropriate permit requirements.

25.4.2 One or more offgas residue streams.

25.4.3 Process waste stream specific to the offgas treatment chosen.

Functional Subelement 25A. Zero Emissions Offgas Treatment

(Optional)

25A.1 Technical Background and Assumptions

25A.1.1 The offgas stream to the offgas treatment sysiem is assumed to contain $\mathrm{H}_{2} \mathrm{O}, \mathrm{CO}_{2}$, High Vapor Pressure Metals (HVPMs) (such as mercury, lead, cadmium, arsenic, etc.), HVPM oxides, halogens, sulfur compounds, combusted organics, particulates, and some radionuclides ( $\mathrm{Cs}^{137}$, potential minor quantities of TRU oxides, and other LLW radionuclides).

25A.1.2 Requirements for this type of offgas system are considered to exceed the requirements necessary to meet present day permitting applications. However, permitting actions are assumed to be greatly enhanced with the stricter requirem $\mathrm{n}$ ts due to the decreased nature of offgas emissions.

25A.1.3 Zero emissions offgas systems of this type are assumed to be only in the research and developrient stage. Proven technology is assumed to be non-existent. A large development effort is assumed to be required for this option.

25A.2 Input

25A.2.1 Offgas stream from the thermal treatment processes.

25A.3 Requirements

25A.3.1 The zero emissions offgas treatment system option shall clean the offgas stream of all constituents with the exception of a minor stream of inert gas. NOTE: These restrictions surpass the present permit requirements for operations. Any minor remaining offgas stream must include full high efficiency particulate air (HEPA) filtering of the stream.

25A.3.2 This option for offgas treatment must convert all offgas constituents to solid or liquid form for further disposition. 
25A.4 Output

25A.4.1 Potential offgas stream consisting of inert gas.

25A.4.2 An offgas residue stream in liquid or solid form.

Functinnal Subelement 26.

26.1 Technical Background and Assumptions

26.2 Input

26.2.1 Residuc from the offgas treatment subsystem.

26.2.2 Borosilicate glass (BSG) frit.

26.3 Requirements

26.3.1 Mixes and blends feedstock to meet melter input requirements.

26.4 Output

26.4.1 Blended BSG and residue feedstock to the melter.

Functional Subelement 27. Offgas Residue Melter

27.1 Technical Background and Assumptions

27.1.1 Assumed melter temperature is a nominal $1100^{\circ} \mathrm{C}$ based on operating temperatures for melters designed for vitrification of high-level waste (HLW) using borosilicate glass.

27.2 Input

27.2.1 Blended feedstock from the mixer subelement consisting of residue from the offgas system and BSG frit.

27.3 Requirements

27.3.1 Operating temperature high enough to melt the BSG frit and the residue, yet low enough to hold the contaminants (high vapor pressure metals, metal oxides, radionuclides, etc.) in solution.

27.3.2 Output must be compatible with downstream processes.

27.3.3 Produce a waste form that is no longer considered a hazardous waste per 40CFR261.

27.4 Output

27.4.1 Molten slag. 
Functional Subelement 28. Offgas Frit/Monolith

28.1 Technical Background and Assumptions

28.1.1 The cor..position of the molten slag output stream is assumed to be a borosilicate glass (BSG) matrix with dissolved metal oxides, and potentially very minor quantities of TRU plus LLW contaminants.

28.2 Input

28.2.1 Molten slag from the offgas residue melter subelement.

\subsection{Requirements}

28.3.1 Receive and handle the molten slag from the melter, and cast it into monoliths or process into a frit form.

28.3.2 Output is compatible with downstream processes

\subsection{Output}

Homogeneous BSG slag in the form of a frit or monolith.

Functional Subelement 29. $\quad$ Post-Treatment Radioactive Assay

29.1 Technical Background and Assumptions

29.1.1 Assume that pretreatment characterization will not satisfy the requirements for classifying output waste form.

29.1.2 An advantage for thermally processing this type of waste is to convert the as-received waste stream into a form which will enhance the ability to obtain TRU concentration data with reduced uncertainty.

29.1.3 The bases for this reduction in uncertainty of assay data are:

- The geometry of the assay form can be optimized for the assay equipment (geometry of choice enables consistent geometrical calibration factors).

- Vitrification and homogenization eliminate density variances.

- Vitrification and homogenization eliminate radionuclide distribution variances (fully dissolved radionuclides and complete mixing).

- Vitrification and homogenization enhance the predictability of self shielding (alpha) unknowns. 
- Vitrification and geometry of choice allow for reduced assay time due to assay of a known form with decreased variances and enables assay data to be collected at a waste throughput rate of tons per day.

- Vitrification and enhanced assay capability allow for post-treatment sort of TRU waste and LLW based on reliable and consistent assay data.

- Vitrification and enhanced assay capability increase the ability to identify radionuclides and to quantify concentrations of the radionuclides. This enhanced capability increases the credibility of the data and alıows for further rational disposition decisions.

29.2 Input

29.2.1 Homogencous IEB or BSG frit or monolith from the thermal treatment subsystems (BSG from offgas stream or IEB from the waste stream).

29.3 Requirements

29.3.1 Identify and quantify radionuclides found in Table 2 of Reference 1 to meet the assay requirements necessary to assign wast? as LLW, reclassificd LLW, or transuranic as follows:

- $\quad$ TRU $>100 \mathrm{nCi} / \mathrm{g}-$ Transuranic Waste

- $10 \mathrm{nCi} / \mathrm{g}<\mathrm{TRU}<100 \mathrm{nCi} / \mathrm{g}$ - Reclassified LLW

- $\quad$ TRU $<10 \mathrm{nCi} / \mathrm{g}-\mathrm{LLW}$

29.4 Output

29.4.1 Radioactive assay data.

29.4.2 An unchanged frit or monolith waste form.

Functional Subclement 30. $\quad$ Post-Treatment Medium Temperature Fusing/Re-melt

\subsection{Technical Background and Assumptions}

30.1.1 This subsystem may be unnecessary if a monolith is cast during initial thermal treatment. The output of frit or monolith from the primary thermal treatment subsystem is dependant on the physical form required to enhance the assay capabilities and produce lower uncertainty reliability assay data.

30.2 Input

30.2.1 Frit or monolith waste from the assay subsystem with TRU $>100 \mathrm{nCi} / \mathrm{g}$.

30.3 Requirements

30.3.1 Fuse or re-melt the IEB frit and cast it into a monolith. (Medium temperature melter operating at a nominal $1400^{\circ} \mathrm{C}$.) 
30.4 Output

30.4 .1

A monolithic IEB waste form.

Functional Subelement 31. Heat Treat/Controlled Cool

31.1 Technical Background and Assumptions

31.1.1 The purpose of this functional subelement is to change the microstructure of the cast monolith waste form such that the resulting waste form has low leach rate and high durability.

31.1.2 This subelement along with the fusing/re-melt subclement may be unnecessary functions if assay systems are identified that can provide high quality, reliabie data from a monolith cast block direct from the primary thermal process subelement.

31.2 Input

31.2 .1

The input for this subelement is a monolith waste form either direct from the primary thermal process subsystem via the assay subsystem or from the fusing/re-melt melter subelement.

31.3 Requirements

31.3.1 Control cooling to optimize the microstructure in order to meet leach rate and durability requirements.

31.3.2 The subsystem shall include nondestructive test capabilitics to verify the integrity of the linal waste form.

31.4 Output

31.4.1 Iron-enriched basalt (IEB) monolith waste form.

Functional Subclement 32. TRU Waste Packaging

32.1 Technical Background and Assumptions

32.1.1 The designated disposition is for interim storage at the INEL pending resolution and opening of a permanent repository for TRU/TRU-Mixed buried waste.

32.2 Input

32.2.1 Monolithic waste forms with concentration of TRU $>100 \mathrm{nCi} / \mathrm{g}$.

32.3 Requirements

32.3.1 Packaging requirements shall meet current INEL TRU Waste Acceptance Critcria ( $\mathrm{sec}$ Reference 7), and RWMC transportation requirements (sec footnote c). 
32.4 Output

32.4 .1

Packaged TRU > $100 \mathrm{nCi} / \mathrm{g}$ waste.

Functional Subclement 33. Final Package Assay

33.1 Trchnical Background and Assumptions

33.2 Input

33.2 .1

Packaged TRU > $100 \mathrm{nCi} / \mathrm{g}$ waste.

33.3 Requirements

33.3.1 Final assay and external contamination sivipe surveys for INEL TRU Waste Acceptance Criteria.

33.4 Output

Packaged TRU > $100 \mathrm{nCi} / \mathrm{g}$ waste.

Functional Subelement 34. Transportation

34.1 Technical Background and Assumptions

34.1.1 Transportation to interim storage can occur within the RWMC and thus will not have to fully comply with EG\&G Hazardous Material Transportation Manual (sec footnote f).

34.2 Input

34.2.1 Waste which is in an acceptable form for transportation to and storage in interim storage.

34.3 Requirements

34.3.1 RWMC transportation requirements (see footnote e).

34.4 Outputs

34.4.1 Packaged waste and its associated assay information delivered to interim storage facilities.

Functional Subclement 35. INEL TRU Interim Storage

35.1 Technical Background and Assumptions 
35.2 Input

35.2 .1

Packaged TRU > $100 \mathrm{nCi} / \mathrm{g}$ waste.

35.3 Requirements

35.3.1 Retrievable storage at the INEL.

35.4 Output

35.4 .1

Packaged TRU > $100 \mathrm{nCi} / \mathrm{g}$ waste.

Functional Subelement 36. $\quad$ Reclassified Low-Level Waste Packagsing

36.1 Technical Background and Assumptions

36.1.1 Assume reclassified LLW has same INEL WAC as LLW.

36.2 Input

36.2.1 Reclassified LLW waste in a frit or monolith form with a concentration of $10 \mathrm{nCi} / \mathrm{g}<\mathrm{TRU}<100 \mathrm{nCi} / \mathrm{g}$.

36.3 Requirements

36.3.1 Packaging shall be per INEL LLW Waste Acceptance Criteria (see Reference 6).

36.3.2 Disposal shall be per INEL LLW disposal criteria (see Reference 6).

36.4 Output

36.4.1 Packaged $10 \mathrm{nCi} / \mathrm{g}<\mathrm{TRU}<100 \mathrm{nCi} / \mathrm{g}$ waste in an approved container.

Functional Subelement 37. Low-Level Waste Packaging INEL Disposal

37.1 Technical Background and Assumptions

37.1.1 The waste derived from fixing the offgas residue into borosilicate glass is assumed to be LLW. The potential for TRU elements to be carried off into the offgas waste stream is considered to be very small. Classification as LLW is verified in the assay subelement (50.0).

37.2 Input

37.2.1 Low-level waste in a borosilicate glass frit or monolith form.

37.3 Requirements

37.3.1 Packaging shall be per INEL LLW Waste Acceptance Criteria (see Reference 6). 
37.4 Output

37.4.1 Packaged LLW. 


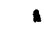




\section{Option D \\ Retrieval/Interim Storage/Melter Treatment}

Functional Subelement 1. Site/Waste Characterization

1.1 Background Technical Information and Assumptions

1.1.1 The waste pits were excavated to the underlying basalt layer and generally backfilled with 2 to $5 \mathrm{ft}$ of soil to provide a level floor. The waste trenches were generally excavated to the basalt layer, approximately $10 \mathrm{ft}$ down and averaged about $7 \mathrm{ft}$ wide and up to $1800 \mathrm{ft}$ long (sec Reference 4). Following excavation, wastes were placed into the pits and trenches. From 1952-1963, the waste containers were stacked to optimize disposal space. During 1963-1969, the waste packages were randomly dumped into the pits and trenches in order to limit worker radiation exposure. In 1969, the waste containers were once again stacked to optimize disposal volume. Once emplaced, the wastes were backfilled with and covered with silty clay and sandy soil.

1.1.2 Physical dimensions of each waste pit and trench (including overburden) are given in Tables 1, 2, and 3 of Reference 4. Details of the characteristics of INEL RWMC soils are given in Tables 4 through 8 of Reference 4 (see Appsndix A).

1.1.3 Figure 7 illustrates a cross-section of a typical Operable Unit (OU) 7-13 waste pit or trench. The figure identifies terms used throughout this report.

1.2 Input

Transuranic (TRU)-Contaminated Waste Pits and Trenches located at the INEL Subsurface Disposal Area (designated as Operable Unit 7-13).

\subsection{Requirements}

The following shall be determined during site/waste characterization:

1.3.1 Vertical boundaries of the waste pits and trenches.

1.3.2 Depth of the basalt underlying the waste pits and trenches.

1.3.3 Depth of the overburden/waste interface for each waste pit and trench.

1.3.4 Location of any outsize waste in the waste seam.

\subsection{Output}

Estimated boundaries of TRU-Contaminated Waste Pits and Trenches. 
Functional Subelement 2. Below-Grade Isolation

2.1 Background Technical Information and Assumptions

2.1.1 The basalt is assumed to offer below-grade horizontal isolation of the waste.

2.1.2 The concern of leakage through the barriers is mitigated by INEL RWMC site renovations performed under the 300-yr Flood Drainage Program.

2.1 .3

The subsurface basalt is at a depth that is less than $30 \mathrm{ft}$ for any given waste pit or trench.

2.1.4 The defined waste seam will be established by an institutional review of the estimated boundaries (see Figure 8). Establishment of the defined waste seam will be performed by institutional entities. This group will be expected to identify the defined waste seam boundary for each pit or trench that includes some margin in addition to the estimated boundary values.

\subsection{Input}

2.2.1 Estimated boundaries of TRU-Contaminated Waste Pits and Trenches.

\subsection{Requirements}

2.3.1 Construct engineered barriers extending vertically from the surface to the basalt at the location of the defined waste seam to provide below-grade isolation of the volume to be remediated.

2.3.2 The engineered barriers shall be designed to meet or exceed all the applicable federal, state, and DOE structural safety standards for mining or excavations.

\subsection{Output}

Below-grade isolation barriers which define the volume of waste to be remediated.

Functional Subelement 3. Above-Grade Containment

\subsection{Background Technical Information and Assumptions}

3.1.1 The entire above-grade containment shall have a facility classification of moderate hazard per UCRL-15910 (see Reference 9).

\subsection{Input}

3.2.1 Below-grade isolation barriers of the volume to be remediated. 


\subsection{Requirements}

3.3.1 The above-grade containment structure(s) must encompass the cntire volume currently being excavated.

3.3.2 The above-grade containment structure(s) shall be designed and constructed to meet the following appi.iable INEL building standards: General Design Criteria (DOE 6430.1A), ${ }^{10}$ Natural Phenomenon (UCRL-15910), ${ }^{9}$ DOE-ID Architectural Engincering Standards, ${ }^{11}$ Opcrational Safety Design Criteria Manual, ${ }^{12}$ Industry Standard Uniform Building Code (UBC), and Nuclear Safcty Analysis Report (DOE Order 5480.23).

3.3.3 The above-grade containment structure(s) shall have the following features:

3.3.3.1 Shall be designed to control contamination from radiological and non-radiological sources to allow maintenance repair or replacement of systems.

3.3.3.2 Shall be designed to allow all necessary activities to support ancillary activities cenducted within the containment structure such as retrieval, package, and transport of excavated waste.

3.3.3.3 Shall be designed to allow ingress/egress of all equipment and personnel necessary to perform all waste retrieval activities.

3.3.3.4 Shall be designed to allow the egress of retrieved waste packaged for transport.

3.3.3.5 Shall have temperature and humidity control such that the environment is regulated within the limits required for maintenance repair or replacement activities in a beta, gamma, alpha, and hazardous contaminated environment.

3.3.4 The above-grade containment structure shall contain all operations from overburden retricval to transport to interim storage/treatment.

\subsection{Output}

3.4.1

Completed and operational containment facility over the isolated region being excavated.

\section{Functional Subclement 4. Overburden Characterization}

\subsection{Background Technical Information and Assumptions}

4.1.1 Prior to any removal of overburden, an extensive characterization of the overburden will be performed.

4.1.2 Data from overburden characterization activities will meet data quality objectives and be useable for risk assessments. 
4.2 Input

4.2 .1

Completed and operational containment facility over the isolated region being excavated.

4.3 Requirements

4.3.1 The characterization will locate any regions of contamination within the pit or trench overburden.

4.3.2 Characterization techniques must be able to sample for radioactive, including TRU, and characteristic and listed hazardous contaminants defined in the BWID Systems Analysis system requirements (see Reference 1).

\subsection{Output}

Location and characterization of radioactive and characteristic and listed hazardouscontaminated overburden.

Functional Subelement $5 . \quad$ Overburden Removal

5.1 Technical Background and Assumptions

\subsection{Input}

Location and characterization of radioactive and characteristic and listed hazardouscontaminated overburden.

\subsection{Requirements}

5.3.1 Up to $75 \%$ of the estimated overburden depth for each pit or trench will be removed. Sufficient overburden will be left in place so as to minimize the possibility of an inadvertent contamination exposure.

The removal process will separate contaminated (radioactive and hazardous) from noncontaminated overburden.

5.3.3 Overburden removal operations must control contamination from beta, gamma, alpha, and the hazardous constituents defined in the BWID Systems Analysis system requirements (see Reference 1) to levels that would allow maintenance to service or repair equipments.

5.3.4 These systems shall meet or exceed all state, federal, and DOE nuclear systems standards for explosion proof, fire protection, and suppression. 


\subsection{Output}

5.4.1 The completed containment facility over the region to be remediated. Up to $75 \%$ of overburden removed.

5.4.2 Contaminated (radioactive and hazardous) overburden.

5.4.3 Noncontaminated overburden.

Functional Subelement $6 . \quad$ Storage of Contaminated Overburden

6.1 Technical Background and Assumptions

6.2 Input

6.2.1 Contaminated (radioactive and hazardous) overburden.

6.3 Requirements

6.3.1 Contaminated overburden must be stored within the above-grade containment structure(s).

6.3.2 Contaminated overburden must be physically separated from retrieved noncontaminated and nonassayed overburden.

6.3.3 Stored contaminated overburden shall not cause a criticality.

6.3.4 Stored contaminated overburden shall have beta, gamma, alpha, and hazardous contamination control compatible with containment requirements of 3.3.3.1.

\subsection{Output}

6.4.1 Stored contaminated overburden.

Functional Subelement 7. Noncontaminated Overburden Storage

7.1 Technical Background and Assumptions

7.2 Input

7.2.1 Retrieved noncontaminated overburden.

\subsection{Requirements}

7.3.1 Retrieved noncontaminated overburden shall be stored in a weather shielded storage. 

noncontaminated overburden shall be surveyed to ensure that it is free of beta, gamma, alpha, and hazardous contamination prior to removal from the containment building.

\subsection{Output}

Stored noncontaminated overburden to be used to refill the remediated pit or trench.

Functional Subelement $8 . \quad \underline{\text { Retrieval }}$

\subsection{Technical Background and Assumptions}

8.1.1 The retrieval functional subelement includes all apparatus to remove all remaining overburden and the waste from the ground, control the spread of contamination during the removal, and convey the retrieved waste from the dig face to a packaging area for eventual shipment for treatmeni.

8.1.2 The assumption for this subelement is that criticality can be prevented.

8.2 Input

8.2.1 The completed containment facility over the region to be remediated. $75 \%$ of estimated overburden depth removed.

\subsection{Requirements}

8.3.1 The retrieval system shall exhume material within the waste seam and transfer that material to a waste conveyance system.

8.3.2 The retrieval systems shall operate within the temperature and humidity limits inside the containment structure.

8.3.3 The retrieval systems must be designed to accommodate operations, maintenance, and repair in a beta, gamma, alpha, and hazardous contamination environment.

8.3.4 The retrieval system shall be designed such that a criticality cannot occur.

8.3.5 Retrieval operations must identify and accommodate atypical waste objects (objects or material incompatible with the retrieval system) or high radiation sources. Identification may involve characterization at the dig-face. NOTE: An acceptable way to "accommodate atypical waste" objects is that the retrieval system may move these objects and stabilize them in the retrieval pit or other designated area to prevent contamination spread and/or to shield high sources of radiation as stated in system requirements (see Reference 1). Retrieval operations may bypass these 
stabilized objects and continue normal operations until such time that special case equipments and procedures will allow for their removal.

8.3 .6

The retrieval system shall meet or exceed all applicable state, federal, and DOE nuclear systems standards for explosion proof, fire protection, and suppression.

8.3.7 Retrieval operations and waste packaging for conveyance will be designed such that personnel exposure to radiation will comply with DOE Order 5480.11, "Radiation Protection for Occupational Workers."

8.3.8 Retrieval operations and waste packaging for conveyance will be designed such that personnel exposure to hazardous materials will comply with all applicable OSHA standards.

\subsection{Output}

Exhumed waste. Waste characteristics defined in BWID Systems Analysis system requirements (see Reference 1 ).

Functional Subelement 9. Waste Conveyance

9.1 Technical Background and Assumptions

9.1.1 The conveyance functional subelement includes all apparatus to convey the retrieved waste or removed overburden within the containment structure.

9.2 Input

9.2.1 Exhumed waste. Waste characteristics defined in BWID System Analysis system requirements (see Reference 1 ).

9.3 Requirements

9.3.1 The waste conveyance system shall be designed so that a criticality event cannot occur.

9.3.2 The waste conveyance system must be designed to accommodate operations, maintenance, and repair in a beta, gamma, alpha, and hazardous contamination environment.

9.3.3 These systems shall meet or exceed all state, federal, and DOE nuclear systems standards for explosion proof, fire protection, and suppression.

9.3.4 The conveyance system shall operate within the temperature and humidity limits in the containment structure. 
9.3.5 The conveyance system will be designed such that personnel exposure to radiation will comply with DOE Order 5480.11, "Radiation Protection for Occupational Workers."

9.3.6 The conveyance system will be designed such that personnel exposure to hazardous materials will comply with all applicable OSHA standards.

\subsection{Output}

9.4.1

Conveyed, exhumed waste Waste characteristics defined in system requirements (see Reference 1).

Functional Subelement $10 . \quad$ Size Reduce

10.1 Technical Background and Assumptions

10.1.1 The size reduction subelement will be capable of size reducing all waste in the waste stream. It is assumed the size reduction subelement will result in a waste stream that meets the size reduction input requirements of the downstream treatment processes (incinerator and/or melter).

10.2 Input

10.2.1 Exhumed waste. Specifics on expected waste types and their contaminants can be found in system requirements (see Reference 1).

10.3 Requirements

10.3.1 A size reduction shall occur to the extent necessary so that the waste is in a form compatible with the radiological/VOC assay technology.

10.3.2 The size reduction system shall be designed to accept all waste of the composition and size described in system requirements (see Reference 1).

10.3.3 The size reduction system shall be designed so that a criticality event cannot occur.

10.3.4 The size reduction system must be designed to accommodate operations, maintenance, and repair in a beta, gamma, alpha, and hazardous contamination environment.

10.3.5 This equipment shall meet or exceed all State, Federal, and DOE nuclear systems standards for explosion proof, fire protection, and suppression.

10.3.6 The size reduction system shall operate within the temperature and humidity limits in the containment structure. 

will comply vith DOE Order 5480.11, "Radiation Protection for Occupational Workers."

The packaging system will be designed such that personnel exposure to hazardous materials will comply with all applicable OSHA standards.

10.4 Output

Sized reduced waste conveyed in a form compatible with assay system.

Functional Subelement 11. Radioactive Plus VOC Assay

11.1 Technical Background and Assumptions

11.1.1 The basis for the Waste Acceptance Criteria for interim storage will be the INEL TRU WAC (see Reference 7). This is assumed to cover Hazardous, Low Level, Low Level Mixed, and TRU Mixed waste.

11.1.2 All waste arriving at the assay system can be assayed.

11.2 Input

11.2.1 Sized reduced waste conveyed in a form compatible with assay system.

11.2.2 Contaminated overburden.

11.3 Requirements

11.3.1 The radioactive/VOC assay system shall be designed so that a criticality event cannot occur.

11.3.2 The radioactive/VOC system must be designed to accommodate operations, maintenance, and repair in a beta, gamma, alpha, and hazardous contamination environment.

11.3.3 This equipment shall meet or exceed all State, Federal, and DOE nuclear systems standards for explosion proof, fire protection, and suppression.

11.3.4 The radioactive/VOC assay for criticality, hazardous, and radioactive constituents shall meet requirements of the interim storage Waste Acceptance Criteria (INEL TRU Waste Acceptance Criteria).

11.3.5 The radioactive/VOC assay systern shall operate within the temperature and humidity limits in the containment structure. 
11.3.6 The radioactive/VOC assay system will be designed such that personnel exposure to radiation will comply with DOE Order 5480.11, "Radiation Protection for Occupational Workers."

11.3.7 The radioactive/VOC assay system will be designed such that personnel exposure to hazardous materials will comply with all applicable OSHA standards.

11.3.8 The assaying system must be able to measure radioactive constituents, including TRU and organic compounds identified in the BWID System Analysis System Requirements (see Reference 1).

\subsection{Output}

11.4.1 Entire waste stream.

11.4.2 Radiological and VOC assay data for the waste stream.

Functional Subelement 12. $\quad$ Packaging

12.1 Technical Background and Assumptions

12.1.1

All retrieved waste (including hazardous, low-level, and mixed) can be packaged and transported to interim storage.

\subsection{Input}

12.2.1 Entire waste stream.

12.2.2 Radiological and VOC assay data for the waste stream.

\subsection{Requirements}

12.3.1 Retrieved and assayed waste stream shall be packaged and labeled to meet all of the RWMC transportation requirements (see References 6 and 7 and footnote e).

12.3.2 Retrieved and assayed waste stream shall be packaged and labeled to meet INEL Transuranic Waste Acceptance Criteria.

12.3.3 The packaging system shall be designed so that a criticality event cannot occur.

12.3.4 The packaging system must be designed to accommodate operations, maintenance, and repair in a beta, gamma, alpha, and hazardous contamination environment.

12.3.5 Equipment shall meet or exceed all State, Federal, and DOE nuclear systems standards for explosion proof, fire protection, and suppression. 

the containment structure.

12.3.7 The packaging system will be designed such that personncl exposure to radiation will comply with DOE Order 5480.11, "Radiation Protection for Occupational Workers."

12.3.8 The packaging system will be designed such that personnel cxposure to hazardous matcrials will comply with all applicable OSHA stanciards.

12.4 Output

12.4.1 Waste which is in an acceptable form for transportation to interim storage and interim storage.

Functional Subelement 13. Transportation

13.1 Technical Background and Assumptions

13.1.1 Transportation to interim storage can occur within the RWMC and thus will not have to fully comply with EG\&G Hazardous Material Transportation Manual (sce footnote f).

\subsection{Input}

13.2.1 Wastc which is in an acceptable form for transportation to and storage in interim storage.

13.3 Requirements

13.3.1 RWMC transportation requirements (sec footnote e).

\subsection{Output}

Packaged waste and its associated assay information delivered to interim storage facilities.

Functional Subelement 14. INEL Interim Storage

\subsection{Technical Background and Assumptions}

14.1.1 Interim storage facilities will be constructed and operated by INEL waste management operations.

14.1.2 Interim storage facilities will aceept all elements of the waste stream (hazardous, low level, low level mixed, TRU, TRU mixed). 
14.1.3 The interim storage facility will be approved to store RCRA wastes.

14.1.4 The interim storage Waste Acceptance Criteria is assumed to be based upon the INEL TRU WAC (see Reference 7).

14.2 Input

14.2.1

Packaged waste and its associated assay information delivered to interim storage facilities.

14.3 Requirements

14.3.1 The interim storage facility will be capable of storing the packaged waste until the thermal treatment facility is ready to accept waste.

14.3.2 Wastc package assay data will be retained.

14.4 Output

14.4.1 Waste which is in an acceptable form for transportation to treatment and waste assay data.

Functional Subelement $15 . \quad$ Transportation

15.1 Technical Background and Assumptions

15.1.1 The treatment facility is not co-located with interim storages; however, it is located within the INEL.

15.2 Input

15.2.1 Waste which is in an acceptable form for transportation to treatment and waste assay data.

15.3 Requirements

15.3.1 INEL transportation requirements (sec footnotes e and f).

15.4 Output

15.4.1 Packaged waste and associated assay information delivered to the pretreatment size reduction subelement. 
Functional Subelement 16. Treatment Facility General Requirements

16.1 Technical Background and Assumptions

16.1.1 The treatment facility has a classification of Moderate Hazard per UCRL-15910 (sce Reference 9).

16.1.2 The entire thermal processing line can be designed, constructed, and tested to maintain alpha contamination controls.

16.1.3 The treatment facility shall meet requests set forth in Nuclear Safety Analysis Reports (DOE Order 5480.23).

16.2 Input

16.2.1 Not applicable

16.3 Requirements

16.3.1 A minimum of double confinement per DOE Order 6430.1A shall exist between normally contaminated areas and uncontrolled areas.

16.3.2 Equipment designs and interfaces shall be designed to maintain alpha, beta, and gamma contamination confinement.

16.3.3 All systems in the treatment facility shall be designed so that a criticality event cannot occur. The treatment facility will follow criticality control requirements per DOE 5480.5 (see Reference 13) and DOE-ID 5480.5A (see Reference 14).

16.3.4 These systems shall meet or exceed all State, Federal, and DOE nuclear systems standards for explosion proof, fire protection, and suppression.

16.3.5 All systems in the treatment facility will be designed such that personnel exposure to radiation will comply with DOE Order 5480.11, "Radiation Protection for Occupational Workers."

16.3.6 All systems in the treatment facility will be designed such that personnel exposure to hazardous materials will comply with all applicable OSHA standards.

16.3.7 The overall treatment facility and operational systems shall meet the requirements for a Radioactive Solid Waste Facility per DOE Order 6430.1A. Section 1324 (see Reference 10).

16.3.8 Additional high-level requirements are contained in Reference 15. 
16.4 Output

16.4.1 Not applicable

Functional Subelement 17. Treatment Facility Receiving

17.1 Technical Background and Assumptions

17.1.1 The receiving subelement performs the functions of accepting transported material supplied by the transportation-for-treatment subelement. Temporary storage for queuing may or may not be a required function, and is dependent upon the specific technologies comprising the technology process options.

17.2 Input

17.2.1 Packaged waste and associated assay information delivered to the treatment facility.

17.3 Requirements

17.3.1 Receive waste from transportation system and store until treatment waste conveyance is ready to accept waste.

17.4 Output

Waste and associated assay information delivered to the treatment waste conveyance system.

Functional Subclement 18. Treatment Waste Conveyance

18.1 Technical Background and Assumptions

18.1.1 The conveyance functional subelement includes all apparatus to convey the retrieved waste or removed overburden within the treatment containment structure.

18.2 Input

18.2.1 Packaged waste and associated assay information delivered to the treatment waste conveyance.

18.3 Requirements

18.3.1 The waste conveyance system must be designed to accommodate operations, maintenance, and repair in a beta, gamma, alpha, and hazardous contamination environment. 
18.3.2 The conveyanec system shall operate within the temperature and humidity limits in the containment structure.

18.3.3 The conveyance subelement must be able to convey all the various forms of wastes within the treatment facility.

18.3.4 The conveyance subelement must con; cy necessary process feedstocks and process by-products.

Waste conveyance shall not change waste characteristics.

18.4 Output

18.4.1 Packaged containers containing quantities of soil and wastc. The waste consists of combustibles and noncombustibles contaminated with organics, radionuclides, and heavy metals. Specifics on expected waste types and their contaminants can be found in the BWID PBTSF Description Report (see Reference 1).

Functional Subclement $19 . \quad$ Size Reduction

19.1 Technical Background and Assumptions

19.1.1 Much effort has been spent on characterization of the RWMC buried waste. The bases for characterization are from past reports, sampling programs, and other efforts; however, since past practices allowed for much less stringent disposal methods, a large degree of inaccuracy must be assumed for any published numbers. The thermal treatment scenarios consider the waste input stream to contain these waste categories plus contaminated soil in varying amounts and percentages.

19.1.2 The size reduction required for processing is less restrictive than for assay monitoring. Thus, assume size reduction performed carlier (subelement 10, Reduce

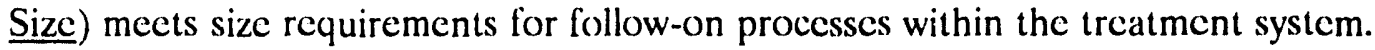
Also, assume that interim storage containers will become part of the waste stream, and thus must be size reduced.

19.2 Input

19.2.1

Packaged and intact containers containing previously sizc-reduced quantitics of soil and waste. The waste consists of combustibles and noncombustibles contaminated with organics, radionuclides, and heavy metals. Specifics on expected waste types and their contaminants can be found in the BWID Systems Analysis System Requirements (see Reference 1).

19.3 Requirements

19.3.1 Process must be capable of reducing size of containers to meet size requirements of downstream treatment process. 
19.4 Output

19.4.1 Reduced waste stream.

Functional Subclement 20. Pre-Treatment Characterization

20.1 Tuchnical Background and Assumptions

20.1.1 It is assumed that the thermal process treatment owner will require independent characterization data for efficient and safe operations.

20.2 Input

20.2.1 Reduced waste stream.

20.3 Requirements

20.3.1 Monitor for gross VOCs identified in BWID Systems Analysis System Requirements (see Reference 1) to assist in melter performance and maintain safe operations.

20.3.2 Monitor for gross radionuclides in BWID Systems Analysis System Requirements (see Reference 1) to assist in process safety controls and quality control of the final waste form.

20.3.3 Monitor as necessary for other gross concentrations of constituents which are difficult to process such as chlorides, HVPMs, and Sulfur. The constituents that are difficult to process are determined by the melting technology chosen.

20.3.4 Data acquisition compatible with down-stream processes.

2().4 Output

20.4.1 Entire waste stream not changed from input.

20.4.2 Data on VOCs, radionuclides, radiation intensity, and other constituents which are difficult to process.

Functional Subclement 21. No Sort

21.1 Technical Background and Assumptions

21.1.1 It is assumed that atypical waste is not included in the main waste stream.

21.2 Input

21.2.1 Entire waste stream from pre-treatment assay and size reduction. 
21..3 Requirements

21.3.1 None

21.4 Output

21.4.1 Same as input.

Functional Subclement 22. Mixer

22.1 Technical Background and Assumptions

22.2 Input

22.2.1 Full waste stream from the radioactive and VOC assay subsystem.

22.2.2 Flux as required for melter process control.

22.2.3 Additional soil from removed underburden if needed for melter process control and final waste form quality control.

22..3 Requirements

22.3.1 Mixes and blends three feedstock in proper proportion to meet melter input requirements.

22.4 Output

22.4.1 Feedstock to the melter.

Functional Subelement 23. $\quad$ Hi-Temperature Pyrolyzing Gas, Oxidizing Slag Mclter

23.1 Technical Background and Assumptions

23.1.1 This option combines incineration technology and melter technology into one operable unit. Units which perform these tasks are commercially available; however, none have been proven for operation in an alpha environment. It is assumed that this type of melter can be successfully operated in an alpha environment.

Note: Estimated melter operating temperature is $>2912^{\circ} \mathrm{F}$ based on References 15 , 16 , and 17.

2.3.2 Input

23.2.1 Blended feedstock from the mixer. Proportions controlled via inputs to the mixer such that output matrix meets output quality control requirements. 


\subsection{Requirements}

23.3.1

The melter shall be capable of destroying all organics and melting all waste forms identified in the input requirements (see Reference 1), interstitial soil, and contaminated overburden.

23.3.2 Operating mode of pyrolyzing atmosphere is above the slag surface, and oxidizing is below the slag surface.

23.3.3 Produce a waste that is no longer considered a hazardous waste per 40CFR261.

\subsection{Output}

Pyrolized offgas waste stream to the afterburner subclement.

23.4.2 Molten slag to the slag frit/monolith subelement.

23.4.3 Tapped molten metals to the molten metals subsystem.

Functional Subcicment 25. Afterburner

25.1 Technical Background and Assumptions

25.1.1 The output stream from the afterburner is assumed to contain $\mathrm{H}_{2} \mathrm{O}, \mathrm{CO}_{2}$, some High Vapor Pressure Metals (HVPMs) (such as mercury, lead, cadmium, arsenic, etc.). HVPM oxides, halogens, sulfur compounds, combusted organics, particulates, and potential radionuclides ( $\mathrm{Cs}{ }^{137}$, potential minor quantities of TRU oxides, and other LLW radionuclides).

25.1.2 One possible design is that the afterburner maintains the offgas stream for a minimum time at a minimum temperature (approximately $>2 \mathrm{sec}$ at $>1010^{\circ} \mathrm{C}$ ) to ensure complete combustion.

25.2 Input

25.2.1 Pyrolyzed oflgas from the melter.

25.3 Requirements

25.3.1 The afterburner shall ensure 99.9999 percent (1 part in $\left.10^{6}\right)$ combustion of all organics in the offgas stream.

25.4 Output

25.4.1 Fully combusted offgas stream. 
Functional Subelement 26. Homogeneous Slag Frit/Monolith

26.1 Technical Background and Assumptions

26.1.1 The composition of the molten slag output stream is assumed to be an iron enriched basalt matrix with dissolved metal oxides, and TRU plus LLW contaminants. This assumption is based on experimental and calculated work as reported in References 16. 17,18 , and 19 .

26.1.2 The output of the melter is assumed to be slag frit or monolith, whichever form enables a high quality, high reliability radioactive assay.

26.2 Input

26.2.1 Tapped molten slag from the melter.

26.3 Requirements

26.3.1 Receive and handle the molten slag from the melter, and cast it into monoliths or process into a frit form.

26.3.2 The waste form matrix will prevent the release of radionuclides and heavy metals.

26.4 Output

26.4.1 Slag in the form of a frit or monolith compatible with downstream processes.

Functional Subelement 27. Tapped Metal

27.1 Technical Background and Assumptions

27.1.1 No radionuclides, or only very minor quantities of radionuclides are expected to be partitioned into the molten metals stream. The radionuclides are expected to be partitioned into the slag, with potentially some carryover into the offgas system. However, radiological controls must still be emplaced on the metals stream.

27.1.2 The metals contained in the molten metal output stream are assumed to be mainly iron $(\mathrm{Fe})$ with trace other metals included.

27.1.3 A high reliability assay of the metals is assumed to be possible in the monolith form.

27.2 Input

27.2.1 Molten metal tapped from the melter.

27.3 Requirements 
27.3.1 Receive and handle the molten metal from the melter and cast into monolith forms.

27.3.2 Produce a waste form that is no longer considered a hazardous waste per 40CFR261.

27.4 Output

27.4.1 A metal monolith waste form.

Functional Subclement 28. Offgas Treatment

28.1 Technical Bacl:ground and Assumptions

28.1.1 The offgas stream to the offgas treatment system is assumed to contain $\mathrm{H}_{2} \mathrm{O}, \mathrm{CO}_{2}$, High Vapor Pressure Metals (HVPMs, mercury, lead, cadmium, arsenic, ctc.), HVPM oxides, halogens, sulfur compounds, combusted organics, particulates, and some radionuclides $\left(\mathrm{Cs}^{137}\right.$, potential minor quantitics of TRU oxides, and other LLW radionuclides).

28.1.2 The offgas unabated release calculations are assumed to confirm the pctential for discharge of radionuclides resulting in effective dose equivalents greater than allowable per 40CFR61.92.

28.2 Input

28.2.1 Offgas stream from the thermal treatment processes.

28.3 Requirements

28.3.1 The offgas treatment system shall clean the offgas stream of all constituents to allow operations within applicable State and Federal air permit requirements.

28.3.2 Per DOE Order 6430.1A, 40CFR60, 40CFR61, and ANSI N13.1, the offgas treatment system shall be equipped with air monitoring instruments to detect radionuclides and hazardous constituents listed in the BWID Systems Analysis System Requirements (see Reference 1). The final released offgas effluent shall be monitored for any normally or accidentally released radionuclides via an isokinetic sampling system.

28.3.3 The offgas system must be maintained at a sufficient negative pressure to draw all gaseous flows through the systems and still maintain adequate negative pressure at the most remote location.

28.4 Output

28.4.1 A cleaned offgas gaseous waste stream which meets all appropriate permit requirements. 
28.4.2 One or more offgas residue streams.

28.4.3 Process waste stream specific to the offgas treatment chosen.

Functional Subelement 28A. Zero Emissions Offgas Treatment

(Optional)

28A.1 Technical Background and Assumptions

28.1.1 The offgas stream to the offgas treatment system is assumed to contain $\mathrm{H}_{2} \mathrm{O}, \mathrm{CO}_{2}$, High Vapor Pressure Mctals (HVPMs, mercury, lead, cadmium, arsenic, etc.), HVPM oxides, halogens, sulfur compounds, combusted organics, particulates, and some radionuclides $\left(\mathrm{Cs}^{137}\right.$, potential minor quantities of TRU oxides, and other LLW radionuclides).

28A.1.2 Requirements for this type of offgas system are considered to exceed the requirements necessary to meet present day permitting applications. However, permitting actions are assumed to be greatly enhanced with the stricter requirements due to the decreased nature of offgas emissions.

28A.1.3 Zero emissions offgas systems of this type are assumed to be only in the research and development stage. Proven technology is assumed to be non-existent. A large development effort is assumed to be required for this option.

28.4.2 Input

28A.2.2 Offgas stream from the thermal treatment processes.

28A.3 Requirements

28. A.3.1 The zero emissions offgas treatment system option shall clean the offgas stream of all constituents with the exception of a minor stream of inert gas. NOTE: these restriclions surpass the present permit requirements for operations. Any minor remaining offgas stream must include full high efliciency particulate air (HEPA) filtering of the stream.

28A.3.2 This option for offgas treatment must convert all offgas constituents to solid or liquid form for further disposition.

28A.4 Output

28.4.4.1 Potential offgas stream consisting of inert gas.

28A.4.2 An offgas residue stream in liquid or solid form. 
Functional Subelement 29.

29.1 Technical Background and Assumptions

29.2 Input

29.2.1 Residue from the offgas treatment subsystem.

29.2.2 Borosilicate glass (BSG) frit.

29.3 Requirements

29.3.1 Mixes and blends feedstock to meet melter input requirements.

29.4 Output

29.4.1 Blended BSG and residue feedstock to the melter.

Functional Subclement 30. $\quad$ Offgas Residue Melter

30.1 Technical Background and Assumptions

30.1.1 Assumed melter temperature is a nominal $1100^{\circ} \mathrm{C}$ based on operating temperatures for melters designed for vitrification of high-level waste (HLW) using borosilicate glass.

30.2 Input

30.2.1 Blended feedstock from the mixer subelement consisting of residuc from the offgas system and BSG frit.

30.3 Requirements

30.3.1 Operating temperature high enough to melt the BSG frit and the residue, yet low enough to hold the contaminants (high vapor pressure metals, metal oxides, radionuclides, etc.) in solution.

30.3.2 Output must be compatible with downstream processes.

30.3.3 Produce a waste form that is no longer considered a hazardous waste per 40CFR261.

30.4 Output

30.4.1 Molten slag.

30.4.2 Offgas effluent. 
Functional Subelement 31. Offgas Frit or Monolith Subsystem

31.1 Technical Background and Assumptions

31.1

The composition of the molten slag output stream is assumed to be a borosilicate glass (BSG) matrix with dissolved metal oxides, and potentially very minor quantities of TRU plus LLW contaminants.

\subsection{Input}

31.2 .1

Molten slag from the offgas residue melter subelement.

\subsection{Requirements}

31.3.1 Receive and handle the molten slag from the melter, and cast it into monoliths or process into a frit form.

31.3.2 Output is compatible with downstream processes.

31.4 Output

Homogeneous BSG slag in the form of a frit or monolith.

Functional Subelement 32. Post-Treatment Radioactive Assay

32.1 Technical Background and Assumptions

32.1.1 Assume that pretreatment characterization will not satisfy the requirements for classifying output waste form.

An advantage for thermally processing this type of waste is to convert the asreceived waste stream into a form which will enhance the ability to obtain TRU concentration data with reduced uncertainty.

The bases for this reduction in uncertainty of assay data are:

- The geometry of the assay form can be optimized for the assay equipment (geometry of choice enables consistent geometrical calibration factors).

- Vitrification and homogenization eliminate density variances.

- Vitrification and homogenization eliminate radionuclide distribution variances (fully dissolved radionuclides and complete mixing).

- Vitrification and homogenization enhance the predictability of self shielding (alpha) unknowns. 
- Vitrification and geometry of choice allow for reduced assay time due to assay of a known form with decreased variances and enables assay data to be collected at a waste throughput rate of tons per day.

- Vitrification and enhanced assay capability allow for post-treatment sort of TRU waste and LLW based on reliable and consistent assay data.

- Vitrification and enhanced assay capability increases the ability to identify radionuclides and to quantify concentrations of the radionuclides. This enhanced capability increases the credibility of the data and allows for further rational disposition decisions.

\subsection{Input}

32.2.1 Homogeneous IEB or BSG frit or monolith from the thermal treatment subsystems (BSG from offgas stream or IEB from the waste stream).

32.3 Requirements

32.3.1 Identify and quantify radionuclides found in Reference 1 to meet the assay requirements necessary to assign waste as LLW, reclassified LLW, or transuranic as follows:

- TRU > $100 \mathrm{nCi} / \mathrm{g}$ - Transuranic Waste

- $10 \mathrm{nCi} / \mathrm{g}<\mathrm{TRU}<100 \mathrm{nCi} / \mathrm{g}$ - Reclassified LLW

- $T R U<10 \mathrm{nCi} / \mathrm{g}-\mathrm{LLW}$

32.4 Output

32.4.1 Radioactive assay data.

32.4.2 An unchanged frit or monolith waste form.

Functional Subelement 33. $\quad$ Post-Treatment Medium Temperature Fusing/Re-melt

33.1 Technical Background and Assumptions

33.1.1 This subsystem may be unnecessary if a monolith is cast during initial thermal treatment. The output of frit or monolith from the primary thermal treatment subsystem is dependant on the physical form required to enhance the assay capabilities and produce lower uncertainty reliability assay data.

3.2 Input

33.2.1 Frit or monolith waste from the assay subsystem with TRU $>100 \mathrm{nCi} / \mathrm{g}$. 


\subsection{Requirements}

33.3.1 Fuse or re-melt the IEB frit and cast it into a monolith. (Medium temperature melter operating at a nominal $1400^{\circ} \mathrm{C}$.)

\subsubsection{Output}

A monolithic IEB waste form.

Functional Subelement 34. $\quad$ Heat Treat/Controlled Cool

34.1 Technical Background and Assumptions

34.1.1 The purpose of this functional subelement is to change the microstructure of the cast monolith waste form such that the resulting waste form has low leach rate and high durability.

34.1.2 This subelement along with the fusing/re-melt subelement may be unnecessary functions if assay systems are identified that can provide high quality, reliable data from a monolith cast block direct from the primary thermal process subelement.

34.2 Input

The input for this subelement is a monolith waste form either direct from the primary thermal process subsystem via the assay subsystem or from the fusing/re-melt melter subelement.

34.3 Requirements

34.3.1 Control cooling to optimize the microstructure in order to meet leach rate and durability requirements.

34.3.2 The subsystem shall include nondestructive test capabilities to verify the integrity of the final waste form.

34.4 Output

34.4.1 Iron-enriched basalt (IEB) monolith waste form.

Functional Subelement 35. TRU Waste Packaging

35.1 Technical Background and Assumptions

35.1.1 The designated disposition is for interim storage at the INEL pending resolution and opening of a permanent repository for TRU/TRU-Mixed buried waste. 
35.2 Input

35.2.1 Monolithic waste forms with concentration of TRU $>100 \mathrm{nCi} / \mathrm{g}$.

35.3 Requirements

35.3.1 Packaging requirements shall meet current INEL TRU Waste Acceptance Criteria (see Reference 7).

35.4 Output

35.4 .1

Packaged TRU > $100 \mathrm{nCi} / \mathrm{g}$ waste.

Functional Subelement 36. Final Package Assay

36.1 Technical Background and Assumptions

36.2 Input

36.2.1 Packaged TRU $>100 \mathrm{nCi} / \mathrm{g}$ waste.

36.3 Requirements

36.3.1 Final assay and external contamination swipe surveys for INEL TRU Waste Acceptance Criteria.

36.4 Output

36.4.1 Packaged TRU $>100 \mathrm{nCi} / \mathrm{g}$ waste.

Functional Subelement 37. INEL TRU Interim Storage

37.1 Technical Background and Assumptions

37.2 Input

37.2.1 Packaged TRU $>100 \mathrm{nCi} / \mathrm{g}$ waste.

37.3 Requirements

37.3.1 Retrievable storage at the INEL.

37.4 Output

37.4.1 Packaged TRU $>100 \mathrm{nCi} / \mathrm{g}$ waste. 
Functional Subelement 38. Reclassified Low-Level Waste Packaging

38.1 Technical Background and Assumptions

38.1.1 Assume reclassified LLW has same INEL WAC as LLW.

38.2 Inpu.

38.2.1 Reclassified LLW waste in a frit or monolith form with a concentration of $10 \mathrm{nCi} / \mathrm{g}$ $<\mathrm{TRU}<100 \mathrm{nCi} / \mathrm{g}$.

38.3 Requirements

38.3 .1

Packaging shall be per INEL LLW Waste Acceptance Criteria (see Reference 6).

38.3.2 Disposal shall be per INEL LLW disposal criteria (see Reference 6).

38.4 Output

38.4.1

Packaged $10 \mathrm{nCi} / \mathrm{g}<\mathrm{TRU}<100 \mathrm{nCi} / \mathrm{g}$ waste in an approved container.

Functional Subelement 39. Low-Level Waste Packaging INEL Disposal

39.1 Technical Background and Assumptions

39.1 .1

The waste derived from fixing the offgas residue into borosilicate glass is assumed to be LLW. The potential for TRU elements to be carried off into the offgas waste stream is considered to be very small. Classification as LLW is verified in the assay subelement (50.0).

39.2 Input

39.2.1 Low-level waste in a borosilicate glass frit or monolith form.

39.3 Requirements

39.3.1 Packaging shall be per INEL LLW Waste Acceptance Criteria (see Reference 6).

39.4 Output

39.4.1

Packaged LLW. 


\section{Option E \\ Retrieval/Interim Storage/Metals Sort/Thermal Treatment}

Functional Subclement 1. Site/Waste Characterization

1.1 Background Technical Information and Assumptions

1.1.1 The waste pits were excavated to the underlying basalt layer and generally backfilled with 2 to $5 \mathrm{ft}$ of soil to provide a level floor. The waste trenches were generally excavated to the basalt layer, approximately $10 \mathrm{ft}$ down and averaged about $7 \mathrm{ft}$ wide and up to $1800 \mathrm{ft}$ long (see Reference 4). Following excavation, wastes were placed into the pits and trenches. From 1952-1963, the waste containcrs were stacked to optimize disposal space. During 1963-1969, the waste packages were randomly dumped into the pits and trenches in order to limit worker radiation exposure. In 1969, the waste containers were once again stacked to optimize disposal volume. Once emplaced, the wastes were backfilled with and covered with silty clay and sandy soil.

1.1.2 Physical dimensions of each waste pit and trench (including overburden) are given in Tables 1, 2, and 3 of Reference 4. Details of the characteristics of INEL RWMC soils are given in Tables 4 through 8 of Reference 4 (sec Appendix A).

1.1.3 Figure 7 illustrates a cross-section of a typical Operable Unit (OU) 7-13 waste pit or trench. The figure identifies terms used throughout this report.

1.2 Input

Transuranic (TRU)-Contaminated Waste Pits and Trenches located at the INEL Subsurface Disposal Arca (designated as Operable Unit 7-13).

1.3 Requirements

The following shall be determined during site/waste characterization:

1.3.1 Vertical boundaries of the waste pits and trenches.

1.3.2 Depth of the basalt underlying the waste pits and trenches.

1.3.3 Depth of the overburden/waste interface for each waste pit and trench.

1.3.4 Location of any outsize waste in the waste scam.

1.4 Output

Estimated boundaries of TRU-Contaminated Waste Pits and Trenches. 
Functional Subelement 2. Below-Grade Isolation

2.1 Background Technical Information and Assumptions

2.1.1 The basalt is assumed to offer below-grade horizontal isolation of the waste.

2.1.2 The concern of leakage through the barriers is mitigated by INEL RWMC site renovations performed under the 300-yr Flood Drainage Program.

2.1.3 The subsurface basalt is at a depth that is less than $30 \mathrm{ft}$ for any given waste pit or trench.

2.1.4 The defined waste seam will be established by an institutional review of the estimated boundaries (see Figure 8). Establishment of the defined waste seam will be performed by institutional entities. This group will be expected to identify the defined waste seam boundary for each pit or trench that includes some margin in addition to the estimated boundary values.

\subsection{Input}

2.2.1 Estimated boundaries of TRU-Contaminated Waste Pits and Trenches.

\subsection{Requirements}

2.3.1 Construct engineered barriers extending vertically from the surface to the basalt at the location of the defined waste seam to provide below-grade isolation of the volume to be remediated.

2.3.2 The engineered barriers shall be designed to meet or exceed all the applicable federal, state, and DOE structural safe!y standards for mining or excavations.

\subsection{Output}

2.4.1 Below-grade isolation barriers which define the volume of waste to be remediated.

Functional Subelement 3. Above-Grade Containment

\subsection{Background Technical Information and Assumptions}

3.1.1 The entire above-grade containment shall have a facility classification of moderate hazard per UCRL-15910 (see Reference 9).

3.2 Input

3.2.1 Belou-grade isolation barriers of the volume to be remediated. 


\subsection{Requirements}

3.3.1 The above-grade containment structure(s) must encompass the entire volume currently being excavated.

3.3.2 The above-grade containment structure(s) shall be designed and constructed to meet the following applicable INEL building standards: General Design Criteria (DOE 6430.1A), ${ }^{10}$ Natural Phenomenon (UCRL-15910), ${ }^{9}$ DOE-ID Architectural Engineering Standards, ${ }^{11}$ Operational Safety Design Critcria Manual, ${ }^{12}$ Industry Standard Uniform Building Code (UBC), and requirements set forth in Nuclear Safety Analysis Reports (DOE Order 5480.23).

3.3.3 The above-grade containment structure(s) shall have the following features:

3.3.3.1 Shall be designed to control contamination from radiological and non-radiological sources to allow maintenance repair or replacement of systems.

3.3.3.2 Shall be designed to allow all necessary activitics to support ancillary activitics conducted within the containment structure such as retrieval, package, and transport of excavated waste.

3.3.3.3 Shall be designed to allow ingress/egress of all equipment and personnel necessary to perform all waste retrieval activities.

3.3.3.4 Shall be designed to allow the egress of retrieved waste packaged for transport.

3.3.3.5 Shall have temperature and humidity control such that the environment is regulated within the limits required for maintenance repair or replacement activities in a beta, gamma, alpha, and hazardous contaminated environment.

3.3.4 The above-grade containment structure shall contain all operations from overburden retrieval to transport to interim storage/treatment.

\subsection{Output}

3.4.1

Completed and operational containment facility over the isolated region being cxcavated.

Functional Subclement $4 . \quad$ Overburden Characterization

4.1 Background Technical Information and Assumptions

4.1.1 Prior to any removal of overburden, an extensive characterization of the overburden will be performed.

4.1.2 Data from overburden characterization activities will meet data quality objectives and be uscable for risk assessments. 


\subsection{Input}

4.2.1 Completed and operational containment facility over the isolated region being excavated.

\subsection{Requirements}

4.3.1

The characterization will locate any regions of contamination within the pit or trench overburden.

Characterization techniques must be able to sample for radioactive, including TRU, and characteristic and listed hazardous contaminants defined in the BWID Systems Analysis system requirements (see Reference 1).

\subsection{Output}

Location and characterization of radioactive and characteristic and listed hazardouscontaminated overburden.

\section{Functional Subelement 5. $\quad$ Overburden Removal}

\subsection{Technical Background and Assumptions}

\subsection{Input}

Location and characterization of radioactive and characteristic and listed hazardouscontaminated overburden.

\subsection{Requirements}

5.3.1 Up to $75 \%$ of the estimated overburden depth for each pit or trench will be removed. Sufficient overburden will be left in place so as to minimize the possibility of an inadvertent contamination exposure.

5.3.2 The removal process will separate cuntaminated (radioactive and hazardous) from noncontaminated overburden.

5.3.3 Overburden removal operations must control contamination from beta, gamma, alpha, and the hazardous constituents defined in the BWID Systems Analysis system requirements (see Reference 1) to levels that would allow maintenance to service or repair equipments.

5.3.4 These systems shall meet or exceed all state, federal, and DOE nuclear systems standards for explosion proof, fire protection, and suppression. 


\subsection{Output}

5.4.1 The completed containment facility over the region to be remediated. Up to $75 \%$ of overburden removed.

5.4.2 Contaminated (radioactive and hazardous) overburden.

5.4.3 Noncontaminated overburden.

Functional Subelement $6 . \quad$ Storage of Contaminated Overburden

6.1 Technical Background and Assumptions

6.2 Input

6.2.1 Contaminated (radioactive and hazardous) overburden.

\subsection{Requirements}

6.3.1 Contaminated overburden must be stored within the above-grade containment structure(s).

6.3.2 Contaminated overburden must be physically separated from retrieved noncontaminated and nonassayed overburden.

6.3.3 Stored contaminated overburden shall not cause a criticality.

6.3.4 Stored contaminated overburden shall have beta, gamma, alpha, and hazardous contamination control compatible with containment requirements of 3.3.3.1.

\subsection{Output}

\subsubsection{Stored contaminated overburden.}

Functional Subelement 7. Noncontaminated Overburden Storage

\subsection{Technical Background and Assumptions}

7.2 Input

7.2.1 Retrieved noncontaminated overburden.

\subsection{Requirements}

7.3.1 Retrieved noncontaminated overburden shall be stored in a weather shielded storage. 
If the noncontaminated storage is located outside the containment building then the noncontaminated overburden shall be surveyed to ensure that it is free of beta, gamma, alpha, and hazardous contamination prior to removal from the containment building.

\subsection{Output}

Stored noncontaminated overburden to be used to refill the remediated pit or trench.

Functional Subelement $8 . \quad$ Retrieval

\subsection{Technical Background and Assumptions}

8.1.1 The retrieval functional subelement includes all apparatus to remove all remaining overburden and the waste from the ground, control the spread of contamination during the removal, and convey the retrieved waste from the dig face to a packaging area for eventual shipment for treatment.

8.1.2 The assumption for this subelement is that criticality can be prevented.

8.2 Input

8.2.1 The completed containment facility over the region to be remediated. $75 \%$ of estimated overburden depth removed.

\subsection{Requirements}

8.3.1 The retrieval system shall exhume material within the waste seam and transfer that material to a waste conveyance system.

8.3.2 The retrieval systems shall operate within the temperature and humidity limits inside the containment structure.

8.3.3 The retrieval systems must be designed to accommodate operations, maintenance, and repair in a beta, gamma, alpha, and hazardous contamination environment.

8.3.4 The retrieval system shall be designed such that a criticality cannot occur.

8.3.5 Retrieval operations must identify and accommodate atypical waste objects (objects or material incompatible with the retrieval system) or high radiation sources. Identification may involve characterization at the dig-face. NOTE: An acceptable way to "accommodate atypical waste" objects is that the retrieval system may move these objects and stabilize them in the retrieval pit or other designated area to prevent contamination spread and/or to shield high sources of radiation as stated in system requirements (see Reference 1). Retrieval operations may bypass these 
stabilized objects and continue normal operations until such time that special case equipments and procedures will allow for their removal.

8.3.6 The retrieval system shall meet or exceed all applicable state, federal, and DOE nuclear systems standards for explosion proof, fire protection, and suppression.

8.3.7 Retrieval operations and waste packagiıg for conveyance will be designed such that personnel exposure to radiation will comply with DOE Order 5480.11, "Radiation Protection for Occupational Workers."

8.3.8 Retrieval operations and waste packaging for conveyance will be designed such that personnel exposure to hazardous materials will comply with all applicable OSHA standards.

8.4 Output

8.4 .1

Exhumed waste. Waste characteristics defined in BWID Systems Analysis system requirements (see Reference 1 ).

Functional Subelement 9. Waste Conveyance

9.1 Technical Background and Assumptions

9.1.1 The conveyance functional subelement includes all apparatus to convey the retrieved waste or removed overburden within the containment structure.

9.2 Input

9.2.1 Exhumed waste. Waste characteristics defined in BWID System Analysis system requirements (see Reference 1).

\subsection{Requirements}

9.3.1 The waste conveyance system shall be designed so that a criticality event cannot occur.

9.3.2 The waste conveyance system must be designed to accommodate operations, maintenance, and repair in a beta, gamma, alpha, and hazardous contamination environment.

9.3.3 These systems shall meet or exceed all state, federal, and DOE nuclear systems standards for explosion proof, fire protection, and suppression.

9.3.4 The conveyance system shall operate within the temperature and humidity limits in the containment structure. 
The conveyance system will be designed such that personnel exposure to radiation will comply with DOE Order 5480.11, "Radiation Protection for Occupational Workers."

9.3.6 The conveyance system will be designed such that personnel exposure to hazardous materials will comply with all applicable OSHA standards.

\subsection{Output}

Conveyed, exhumed waste. Waste characteristics defined in system requirements (see Reference 1).

\section{Functional Subelement 10. $\quad$ Size Reduce}

\subsection{Technical Background and Assumptions}

10.1 .1

The size reduction subelement will be capable of size reducing all waste in the waste stream. It is assumed the size reduction subelement will result in a waste stream that meets the size reduction input requirements of the downstream treatment processes (incinerator and/or melter).

10.2 Input

10.2.1 Exhumed waste. Specifics on expected waste types and their contaminants can be found in the system requirements (see Reference 1).

10.3 Requirements

10.3.1 A size reduction shall occur to the extent necessary so that the waste is in a form compatible with the radiological/VOC assay technology.

10.3.2 The size reduction system shall be designed to accept all waste of the composition and size described in the system requirements (see Reference 1).

10.3.3 The size reduction system shall be designed so that a criticality event cannot occur.

10.3.4 The size reduction system must be designed to accommodate operations, maintenance, and repair in a beta, gamma, alpha, and hazardous contamination environment.

10.3.5 This equipment shall meet or exceed all State. Federal, and DOE nuclear systems standards for explosion proof, fire protection, and suppression.

10.3.6 The size reduction system shall operate within the temperature and humidity limits in the containment structure. 
10.3.7 The packaging system will be designed such that personnel exposure to radiation will comply with DOE Order 5480.11, "Radiation Protection for Occupational Workers."

10.3.8 The packaging system will be designed such that personnel exposure to hazardous materials will comply with all applicable OSHA standards.

10.4 Output

10.4.1

Sized reduced waste conveyed in a form compatible with assay system.

Functional Subelement 11. Radioactive Plus VOC Assay

11.1 Technical Background and Assumptions

11.1.1 The basis for the Waste Acceptance Criteria for interim storage will be INEL TRU WAC (see Reference 7), and thus is assumed to cover hazardous, low-level, lowlevel mixed, and TRU mixed waste.

11.1.2 All waste arriving at the assay system can be assayed.

11.2 Input

11.2.1 Sized-reduced waste conveyed in a form compatible with assay system.

11.2.2 Contaminated overburden.

11.3 Requirements

11.3.1 The radioactive/VOC assay system shall be designed so that a criticality event cannot occur.

11.3.2 The radioactive/VOC system must be designed to accommodate operations, maintenance, and repair in a beta, gamma, alpha, and hazardous contamination environment.

11.3.3 This equipment shall meet or exceed all State, Federal, and DOE nuclear systems standards for explosion proof, fire protection, and suppression.

11.3.4 The radioactive/VOC assay for criticality, hazardous, and radioactive constituents shall meet requirements of the interim storage Waste Acceptance Criteria (INEL TRU Waste Acceptance Criteria).

11.3.5 The radioactive/VOC assay system shall operate within the temperature and humidity limits in the containment structure. 
11.3.6 The radioactive/VOC assay system will be designed such that personnel exposure to radiation will comply with DOE Order 5480.11, "Radiation Protection for Occupational Workers."

11.3.7 The radioactive/VOC assay system will be designed such that personnel cxposurc to hazardous materials will comply with all applicable OSHA standards.

11.3.8 The assaying system must be able to measure radioactive constitucnts, including TRU and organic compounds identified in the BWID System Analysis System Requirements (sec Relerence 1).

\subsection{Output}

11.4.1 Entire waste stream.

11.4.2 Radiological and VOC assay data for the waste stream.

Functional Subelement 12. $\quad$ Packaging

12.1 Technical Background and Assumptions

12.1.1 All retrieved waste (including hazardous, low-level, and low-level mixed) can be packaged and transported to interim storage.

12.2 Input

12.2.1 Entire waste stream.

12.2.2 Radiological and VOC assay data for the waste stream.

12.3 Requirements

12.3.1 Retricved and assayed waste stream shall be packaged and labeled to meet all of the RWMC transportation requirements (see References 6 and 7 and footnote e).

12.3.2 Retrieved and assayed waste stream shall be packaged and labeled to meet INEL Transuranic Waste Acceptance Criteria.

12.3.3 The packaging system shall be designed so that a criticality event cannot occur.

12.3.4 The packaging system must be designed to accommodate operations, maintenance, and repair in a beta. gamma, alpha. and hazardous contamination environment.

12.3.5 Equipment shall meet or exeed all State. Federal, and DOE nuclear systems standards for explosion proof, fire protection, and suppression. 
The packaging system shall operate within the temperature and humidity limits in the containment structure.

12.3.7 The packaging system will be designed such that personnel exposure to radiation will comply with DOE Order 5480.11, "Radiation Protection for Occupational Workers."

12.3.8 The packaging system will be designed such that personnel exposure to hazardous materials will comply with all applicable OSHA standards.

12.4 Output

12.4.1 Waste that is in an accetable form for transportation to interim storage and interim storage.

Functional Subelement 13. Transportation

13.1 Technical Background and Assumptions

13.1.1 Transportation to interim storage can occur within the RWMC and thus will not have to fully comply with the EG\&G Hazardous Material Transportation Manual (sec footnote $\mathrm{f}$ ).

13.2 Input

13.2.1 Waste which is in an acceptable form for transportation to and storage in interim storage.

13.3 Requirements

13.3.1 RWMC transportation requirements (see footnote e).

\subsection{Output}

13.4.1 Packaged waste and its associated assay information delivered to interim storage facilities.

Functional Subclement 14. INEL Interim Storage

14.1 Technical Background and Assumptions

14.1.1 Interim storage facilities will be constructed and operated by INEL waste management operations.

14.1.2 Interim storage lacilities will aceept all elements of the waste stream (hazardous, low-level. low-level mixed. TRU. and TRU-mixed). 
14.1.3 The interim storage facility will be approved to store RCRA wastes.

14.1.4 The interim storage Waste Acceptance Criteria is assumed based upon the INEL TRU WAC (see Reference 7).

\subsection{Input}

14.2.1 Packaged waste and its associated assay information delivered to interim storage facilities.

\subsection{Requirements}

14.3.1 The interim storage facility will be capable of storing the packaged waste until the thermal treatment facility is ready to accept waste.

14.3.2 Waste package assay data will be retained.

14.4 Output

14.4 .1

Waste which is in an acceptable form for transportation to treatment and waste assay data.

Functional Subelement $15 . \quad$ Transportation to Treatment

15.1 Technical Background and Assumptions

15.1.1 The treatment facility is not co-located with interim storages; however, it is located within the INEL.

15.2 Input

15.2.1 Waste which is in acceptable form for transportation to treatment and waste assay data.

15.3 Requirements

15.3 .1

INEL transportation requirements (see footnotes e and $\mathfrak{f}$ ).

15.4 Output

15.4.1 Packaged waste and associated assay information delivered to the pretreatment size reduction subelement. 
Functional Subelement 16. Treatment Facility General Requirements

16.1 Technical Background and Assumptions

16.1.1 The treatment facility has a classification of Moderate Hazard per UCRL-15910 (sec Reference 9).

16.1.2 The entire thermal processing line can be designed, constructed and tested to maintain alpha contamination controls.

16.1.3 The treatment facility shall meet requirements outlined in Nuclear Safety Analysis (Reports DOE Order 5480.23).

16.2 Input

16.2.1 Not applicable

16.3 Requirements

16.3.1 A minimum of double confinement per DOE Order 6430.1A shall exist betwecn normally contaminated areas and uncontrolled areas.

16.3.2 Equipment designs and interfaces shall be designed to maintain alpha, beta, and gamma contamination confinement.

16.3.3 All systems in the treatment facility shall be designed so that a criticality event cannot occur. The treatment facility will follow criticality control requirements per DOE 5480.5 (see Reference 13) and DOE-ID 5480.5A (sec Reference 14).

16.3.4 These systems shall meet or exceed all State, Federal, and DOE nuclear systems standards for explosion proof, fire protection and suppression.

16.3.5 All systems in the treatment facility will be designed such that personnel cxposure to radiation will comply with DOE Order 5480.11, "Radiation Protection for Occupational Workers."

16.3.6 All systems in the treatment facility will be designed such that personnel exposure to hazardous materials will comply with all applicable OSHA standards.

16.3.7 The overall treatment facility and operational systems shall meet the requirements for a Radioactive Solid Waste Facility per DOE Order 6430.1A. Section 1324 (see Reference 10).

16.3.8 Additional high-level requirements are contained in Reference 15. 
16.4 Output

16.4.1 Not applicable

Functional Subclement 17. Treatment Facility Receiving

17.1 Technical Background and Assumptions

17.1.1 The receiving subelement performs the functions of accepting transported material supplied by the transportation-for-treatment subelement. Temporary storage for queuing may or may not be a required function, and is dependent upon the specific technologies comprising the technology process options.

17.2 Input

17.2.1 Packaged waste and associated assay information delivered to the treatment facility.

17.3 Requirements

17.3.1 Receive waste from transportation system and store until conveyance is ready to accept waste.

17.4 Output

17.4.1 Waste and associated assay information delivered to the treatment waste conveyance system.

Functional Subelement 18. Treatment Waste Conveyance

18.1 Technical Background and Assumptions

18.1.1 The conveyance functional subelement includes all apparatus to convey the retricved waste or removed overburden within the treatment containment structure.

18.2 Input

18.2.1 Packaged waste and associated assay information delivered to the treatment waste conveyance.

18.3 Requirements

18.3.1 The waste conveyance system must be designed to accommodate operations, maintenance, and repair in a beta, gamma, alpha, and hazardous contamination environment.

18.3.2 The conveyance system shall operate within the temperature and humidity limits in the containment structure. 
18.3 .3

The conveyance subelement must be able to convey all the various forms of wastes within the treatment facility.

18.3.4 The conveyance subelement must convey neecssary process fecdstocks and process by-products.

18.3.5 Waste conveyance shall not change waste characteristics.

18.4 Output

Packaged containers containing quantities of soil and waste. The waste consists of combustibles and noncombustibles contaminated with organics, radionuclides, and heavy metals. Specifics on expected waste types and their contaminants can be found in Section 2.0 of Reference 1.

Functional Subelement 19. Size Reduction

19.1 Technical Background and Assumptions

19.1.1

Much effort has been spent on characterization of the RWMC buried waste. Because of less stringent disposal methods, a large degrec of inaccuracy must be assumed for any published numbers. The thermal treatment scenarios consider the waste input stream to contain these waste categories plus contaminated soil in varying amounts and percentages.

19.1.2 The size reduction required for processing is less restrictive than for assay monitoring. Thus, assume size reduction performed earlier (Subelement 10, Reduce

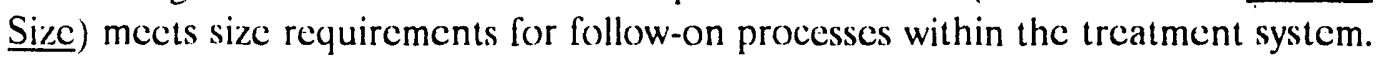
Also, assume that interim storage containers will become part of the waste stream. and thus must be size reduced.

19.2 Input

19.2.1 Packaged and intact containers containing previously size-reduced quantities of soil and waste. The waste consists of combustibles and noncombustibles contaminated with organics, radionuclides, and heavy metals. Specifics on expected waste types and their contaminants can be found in Reference 1 .

19.3 Requirements

19.3 .1

Process must be capable of reducing size of containers to mect size requirements of downstream treatment process.

19.4 Output

Reduced waste stream. 
Functional Subelement 20. Pre-Treatment Characterization

20.1 Technical Background and Assumptions

20.1.1 It is assumed that the thermal process treatment owner will require independent characterization data for efficient and safe operations.

20.2 Input

20.2.1 Reduced waste stream.

20.3 Requirements

20.3.1 Monitor for gross VOCs identified in Table 2 of Reference 1 to assist in melter performance and maintain safe operations.

20.3.2 Monitor for gross radionuclides and radiation levels to assist in process safety controls and quality control of the final waste form.

20.3.3 Monitor as necessary for other gross concentrations of constituents which are difficult to process such as chlorides, HVPMs, and Sulfur. The constituents which are difficult to process are determined by the melting technology chosen.

20.3.4 Data acquisition compatible with downstream processes.

\subsection{Output}

20.4.1

Entire waste stream not changed from input.

20.4.2 Data on VOCs, radionuclides, radiation intensity, and other constituents which are difficult to process.

Functional Subelement 21. Metals Sort

21.1 Technical Background and Assumptions

21.1.1 It is assumed that atypical waste is not included in the main waste stream.

\subsection{Input}

21.2.1

Reduced waste stream from the pretreatment characterization and size reduction subelements.

21.3 Requirements

21.3.1 Sort metals from the waste stream. 


\subsection{Output}

21.4.1

Waste stream less sorted metals (combustibles, non-combustibles, soil, organics, and residual metals from inefficient sorting).

21.4.2 Waste stream of metals only and residual soil and organics from inefficient sort.

Functional Subelement 22. Thermal Desorber

22.1 Technical Background and Assumptions

22.1.1 The thermal desorber functional subelement disassociates nitrate compounds that could cause combustible pulsing of the incinerator. The thermal desorber operating temperature is based on a temperature which is high enough for initial thermal decomposition of nitrates (potassium nitrate decomposes at $400^{\circ} \mathrm{C}$ and sodium nitrate decomposes at $380^{\circ} \mathrm{C}$ ).

\subsection{Input}

22.2.1

A size-reduced waste stream consisting of combustibles, noncombustibles, soil, organics, plus some residuals metals.

22.2 .2

Offgas from the High Temperature Oxidizing Slag, Oxidizing Metal/Metal Tapping Melter

22.3 Requirements

22.3.1

22.3.2

22.3.4

\subsection{Output}

Heat all waste stream constituents to a temperature of TBD degrees centigrade.

Hold preheated waste stream constituents at a temperature of TBD degrees for a time of TBD minutes.

Meet input requirements of downstream processes.

Process main waste stream at system throughput rate.

Preheated non-metallic waste stream.

Offgas. 
Functional Subelement 23. Incinerator

23.1 Technical Background and Assumptions

23.1.1 Incincration/pyrolysis of the waste stream is performed to combust the majority of the combustible portion (including organics) of the waste strcam. Low temperature incincration may be preferred for reduction in corrosion and crosion of the incinerator. This also may result in reduction in the plugging potential of the ash and residuals in the material handling system.

23.1.2 It is also very desirable to adopt a design that will produce a minimum offgas flow rate. This will simplify any „secessary offgas treatment systcm.

23.2 Input

23.2.1 Prcheated non-metallic waste stream.

23.2.2 Offgas from the Thermal Desorber subelement.

23.3 Requirements

23.3.1 Incineration/pyrolysis of the waste stream.

23.3.2 Meet downstream input requirements and system throughput processing rate.

23.4 Output

23.4.1 Pyrolized ash.

23.4.2 A combusted oflgas stream plus minor products of incomplete combustion.

Functional Subclement 24. Afterburner

24.1 Technical Background and Assumptions

24.1.1 The output stream from the afterburner is assumed to contain $\mathrm{H}_{2} \mathrm{O}, \mathrm{CO}_{2}$,and High Vapor Pressure Metals (HVPMs such as mercury, lead, cadmium, arscnic, etc.), HVPM oxides, halogens, sulfur compounds, combusted organics, particulates, and some radionuclides ( $\mathrm{Cs}^{137}$. potential minor quantities of TRU oxides, and other $L L W$ radionuclides).

24.1.2 One possible design will maintain the offgas stream for a minimum time at a minimum temperature (approximately $>2 \mathrm{sec}$ at $>101\left(0^{\circ} \mathrm{C}\right.$ ) to) ensure complete combustion. 
24.2 Input

24.2.1 A combusted offgas stream plus minor products of incomplete combustion from the incinerator.

\subsection{Requirements}

24.3.1 The afterburner shall ensure 99.9999 percent (1 part in $10^{6}$ ) combustion of all organics in the offgas stream.

24.4 Output

24.4.1 Combusted offgas stream.

Functional Subelement 25. Mixer

25.1 Technical Background and Assumptions

25.2 Input

25.2.1 Metals (plus residuals) from the metals sort subelement.

25.2.2 Pyrolized ash from the incinerator.

25.2.3 Flux if required for melter process control.

25.2.4 Basaltic soil (contaminated overburden soil) as needed for melter process control and final waste form quality control.

25.3 Requirements

25.3.1 Mix and blend feedstock.

25.4 Output

25.4.1 Blended feedstock to the melter.

Functional Subelement 26. Oxidizing Slag, Oxidizing Metal/Metal Tapping Melter

26.1 Technical Background and Assumptions

26.1.1 The composition of the molten slag output stream is assumed to be an iron-enriched basalt matrix with dissolved metal oxides, and TRU plus LLW contaminants. This assumption is based on work as reported in References 16, 17, 18, and 19. 
The offgas stream from the high temperature melter is assumed to potentially contain $\mathrm{H}_{2} \mathrm{O}, \mathrm{CO}_{2}$, High Vapor Pressure Metals (HVPMs, such as mercury, lead, cadmium, arsenic, etc.). HVPM oxides, halogens, sulfur compounds, combusted organics, particulates, and some radionuclides $\left(\mathrm{Cs}^{137}\right.$, potential minor quantities of TRU oxides, and other LLW radionuclides).

26.1.3 The metals contained in the molten metal output stream are assumed to be mainly iron (Fe) with trace other metals included.

26.2 Input

26.2.1

Blended feedstock from the mixer consisting of metals plus residuals from the metals sort subelement, ash plus soil plus residuals from the incinerator, flux as required for melter process control, and soil as needed for melter process control and final waste form quality control.

26.2.2

Oxygen gas.

26.3 Requirements

26.3.1 Meet input requirements of downstream subelements.

26.3.2 Operating temperature high enough to melt metals and melt the basaltic soils maintaining an adequate viscosity for the Homogeneous slag Frit/Monolith subelement.

26.3.3 The melter output shall contain none of the organic constituents found in the system requirements (see Reference 1 ).

26.3.4 Produce a waste form that is no longer considered a hazardous waste per 40CFR261.

\subsection{Output}

An offgas waste stream to the thermal desorber/incinerator or afterburner.

26.4.2 Molten slag to the slag handling subsystem.

26.4.3 Tapped molten metals to the molten metals subsystem.

Functional Subelement 27. Homogeneous Slag Frit/Monolith

27.1 Technical Background and Assumptions

27.1.1 The composition of the molten slag output stream is assumed to be an iron-enriched basalt matrix with dissolved metal oxides, and TRU plus LLW contaminants. This 
assumption is based on experimental and calculated work as reported in References 16, 17, 18, and 19.

27.1.2 The output of the melter is assumed to be slag frit or monolith, whichever form enables a high quality, high reliability radioactive assay.

27.2 Input

27.2.1 Tapped molten slag from the melter.

27.3 Requirements

27.3.1 Receive and handle the molten slag from the melter, and cast it into monoliths or process into a frit form.

27.3.2 The waste form will prevent the release of radionuclides and heavy metals.

27.4 Output

27.4.1 Slag in the form of a frit or monolith compatible with downstream processes.

Functional Subelement 28. Tapped Metal

28.1 Technical Background and Assumptions

28.1.1 No radionuclides, or only very minor quantities of radionuclides, are expected to be partitioned into the molten metals stream. The radionuclides are expected to be partitioned into the slag, with potentially some carryover into the offgas system. However, radiological controls must still be emplaced on the metals stream.

28.1.2 The metals contained in the molten metal output stream are assumed to be mainly iron (Fe) with trace other metals included.

28.1.3 A high reliability assay of the metals is assumed to be possible in the monolith form.

28.2 Input

28.2.1 Molten metal tapped from the melter.

\subsection{Requirements}

28.3.1 Receive and handle the molten metal from the melter and cast into monolith forms.

28.3.2 Produce a waste form that is no longer considered a hazardous waste per 40CFR261. 
28.4 Output

28.4.1 A metal monolith waste form.

Functional Subclement 29. Offgas Treatment

29.1 Technical Background and Assumptions

29.1.1 The offgas stream to the offgas treatment system is assumed to contain $\mathrm{H}_{2} \mathrm{O}, \mathrm{CO}_{2}$, High Vapor Pressure Metals (HVPMs, mercury, lead, cadmium, arsenic, etc.), HVPM oxides, halogens, sulfur compounds, combusted organics, particulates, and some radionuclides $\left(\mathrm{Cs}^{137}\right.$, potential minor quantities of TRU oxides, and other LLW radionuclides).

29.1.2 The offgas unabated release calculations are assumed to confirm the potential for discharge of radionuclides resulting in effective dose equivalents greater than allowable per 40CFR61.92.

29.2 Input

29.2.1

Offgas stream from the thermal treatment processes.

29.3 Requirements

29.3.1 The offgas treatment system shall clean the offgas stream of all constituents to allow operations within applicable State and Federal air permit requirements.

29.3 .2

Per DOE Order 6430.1A, 40CFR60, 40CFR61, and ANSI N13.1, the offgas treatment system shall be equipped with air monitoring instruments to detect radionuclides and hazardous constituents listed in the BWID Systems Analysis System Requirements (see Reference 1). The final released offgas effluent shall be monitored for any normally or accidentally released radionuclides via an isokinetic sampling system.

29.3.3 The offgas system must be maintained at a sufficient negative pressure to draw all gaseous flows through the systems and still maintain adequate negative pressure at the most remote location.

29.4 Output

29.4 .1

A cleaned offgas gaseous waste stream which meets all appropriate permit requirements.

29.4.2 One or more offgas residue streams.

29.4.3 Process waste stream specific to the offgas treatment chosen. 
Functional Subelement 29A. Zero Emissions Offgas Treatment

(Optional)

29A.1 Technical Background and Assumptions

29A.1.1 The offgas stream to the offgas treatment system is assumed to contain $\mathrm{H}_{2} \mathrm{O}, \mathrm{CO}_{2}$, High Vapor Pressure Metals (HVPMs, mercury, lead, cadmium, arsenic, etc.), HVPM oxides, halogens, sulfur compounds, combusted organics, particulates, and some radionuclides $\left(\mathrm{Cs}^{137}\right.$, potential minor quantities of TRU oxides, and other LLW radionuclides).

29A.1.2 Requirements for this type of offgas system are considered to exceed the requirements necessary to meet present day permitting applications. However, permitting actions are assumed to be greatly enhanced with the stricter requirements due to the decreased nature of offgas emissions.

29A.1.3 Zero emissions offgas systems of this type are assumed to be only in the research and development stage. Proven technology is assumed to be non-existent. A large development effort is assumed to be required for this option.

29A.2 Input

29A.2.2 Offgas stream from the thermal treatment processes.

29A.3 Requirements

29A.3.1 The zero emissions offgas treatment system option shall clean the offgas stream of all constituents with the exception of a minor stream of inert gas. NOTE: These restrictions surpass the present permit requirements for operations. Any minor remaining offgas stream must include full high efficiency particulate (HEPA) air filtering of the stream.

29A.3.2 This option for offgas treatment must convert all offgas constituents to solid or liquid form for further disposition.

29A.4 Output

29A.4.1 Potential offgas stream consisting of inert gas.

29A.4.2 An offgas residue stream in liquid or solid form. 
Functional Subelement $30 . \quad \underline{\text { Mixer }}$

30.1 Technical Background and Assumptions

30.2 Input

30.2.1 Residuc from the offgas treatment subsystem.

30.2.2 Borosilicatc glass (BSG) frit.

30..3 Requirements

30.3.1 Mixes and blends feedstock to meet melter input requircments.

30.4 Output

30.4.1 Blended BSG and residue feedstock to the melter.

Functional Subclement 31. $\quad$ Offgas Residue Melter

31.1 Technical Background and Assumptions

31.1.1 Assumed melter temperature is a nominal $1100^{\circ} \mathrm{C}$ based on operating temperatures for melters designed for vitrification of high-level waste (HLW) using borosilicate glass.

31.2 Input

31.2.1 Blended feedstock from the mixer subelement consisting of residue from the offgas system and BSG frit.

31.3 Requirements

31.3.1 Operating temperature high enough to melt the BSG frit and the residuc, yet low enough to hold the contaminants (high vapor pressure metals, metal oxides, radionuclides, etc.) in solution.

31.3.2 Output must be compatible with downstream processes.

31.3.3 Produce a waste for that is no longer considered a hazardous waste per 40CFR261.

31.4 Output

31.4.1 Molten slag.

31.4.2 Offgas effluent. 
Functional Subelement 32. Offgas Frit/Monolith

32.1 Technical Background and Assumptions

32.1.1 The composition of the molten slag output stream is assumed to be a borosilicate glass (BSG) matrix with dissolved metal oxides, and potentially very minor quantities of TRU plus LLW contaminants.

32.2 Input

32.2.1 Molten slag from the offgas residue melter subelement.

\subsection{Requirements}

32.3.1 Receive and handle the molten slag from the melter, and cast it into monoliths or process into a frit form.

32.3.2 Output is compatible with downstream processes

32.4 Output

32.4.1

Homogeneous BSG slag in the form of a frit or monolith.

Functional Subelement 33. Post-Treatment Radioactive Assay

33.1 Technical Background and Assumptions

33.1.1 Assume that pretreatment characterization will not satisfy the requirements for classifying the output waste form.

33.1.2 An advantage for thermally processing this type of waste is to convert the asreceived waste stream into a form which will enhance the ability to obtain TRU concentration data with reduced uncertainty.

33.1.3 The bases for this reduction in uncertainty of assay data are:

- The geometry of the assay form can be optimized for the assay equipment (geometry of choice enables consistent geometrical calibration factors).

- Vitrification and homogenization eliminate density variances.

- Vitrification and homogenization eliminate radionuclide distribution variances (fully dissolved radionuclides and complete mixing).

- Vitrification and homogenization enhance the predictability of self shielding (alpha) unknowns. 
- Vitrification and geometry of choice allow for reduced assay time due to assay of a known form with decreased variances and enables assay data to be collected at a waste throughput rate of tons per day.

- Vitrification and enhanced assay capability allow for post-treatment sort of TRU waste and LLW based on reliable and consistent assay data.

- Vitrification and enhanced assay capability increase the ability to identify radionuclides and to quantify concentrations of the radionuclides. This enhanced capability increases the credibility of the data and allows for further rational disposition decisions.

\subsection{Input}

33.2 .1

Homogeneous IEB or BSG frit or monolith from the thermal treatment subsystems (BSG from offgas stream or IEB from the waste stream).

\subsection{Requirements}

33.3.1

Identify and quantify radionuclides to meet the assay requirements necessary to assign waste as LLW, reclassified LLW, or Transuranic as follows:

- $\quad$ TRU $>100 \mathrm{nCi} / \mathrm{g}$ - Transuranic Waste

- $10 \mathrm{nCi} / \mathrm{g}<\mathrm{TRU}<100 \mathrm{nCi} / \mathrm{g}$ - Reclassified LLW

- $T R U<10 \mathrm{nCi} / \mathrm{g}-\mathrm{LLW}$

\subsection{Output}

33.4.1 Radioactive assay data.

33.4.2 An unchanged frit or monolith waste form.

Functional Subelement 34. Post-Treatment Medium Temperature Fusing/Re-melt

\subsection{Technical Background and Assumptions}

34.1.1 This subsystem may be unnecessary if a monolith is cast during initial thermal treatment. The output of frit or monolith from the primary thermal treatment subsystem is dependant on the physical form required to enhance the assay capabilities and produce lower uncertainty reliability assay data.

34.2 Input

Frit or monolith waste from the assay subsystem with TRU $>100 \mathrm{nCi} / \mathrm{g}$. 
34.3 Requirements

34.3.1 Fuse or re-melt the IEB frit and cast it into a monolith. (Medium temperature melter operating at a nominal $1400^{\circ} \mathrm{C}$.)

34.4 Output

34.4.1 A monolithic IEB waste form.

Functional Subelement 35. Heat Treat/Controlled Cool

35.1 Technical Background and Assumptions

35.1.1 The purpose of this functional subelement is to change the microstructure of the cast monolith waste form such that the resulting waste form has low leach rate and high durability.

35.1.2 This subelement, along with the fusing/re-melt subelement, may be unnecessary functions if assay systems are identified that can provide high quality, reliable data from a monolith cast block direct from the primary thermal process subclement.

35.2 Input

35.2.1 The input for this subelement is a monolith waste form either direct from the primary thermal process subsystem via the assay subsystem or from the fusing/rc-melt melter subelement.

\subsection{Requirements}

35.3.1 Control cooling to optimize the microstructure in order to meet lach rate and durability requirements.

35.3.2 The subsystem shall include nondestructive test capabilities to verify the integrity of the final waste form.

35.4 Output

Iron-enriched basalt (IEB) monolith waste form.

Functional Subclement 36. TRU Waste Packaging

36.1 Technical Background and Assumptions

36.1.1 The designated disposition is for interim storage at the INEL pending resolution and opening of a permanent repository for TRU/TRU-Mixed buricd'waste. 
36.2 Input

36.2.1 Monolithic waste forms with concentration of TRU $>100 \mathrm{nCi} / \mathrm{g}$.

36.3 Requirements

36.3 .1

Packaging requirements shall meet current INEL TRU Waste Acceptance Criteria (see Reference 7).

36.4 Output

36.4 .1

Packaged TRU > $100 \mathrm{nCi} / \mathrm{g}$ waste.

Functional Subelement 37. Final Package Assay

37.1 Technical Background and Assumptions

37.2 Input

37.2 .1

Packaged TRU > $100 \mathrm{nCi} / \mathrm{g}$ waste.

37.3 Requirements

37.3.1 Final assay and external contamination swipe surveys for INEL TRU Waste Acceptance Criteria.

37.4 Output

37.4.1 Packaged TRU $>100 \mathrm{nCi} / \mathrm{g}$ waste.

Functional Subelement 38. INEL TRU Interim Storage

38.1 Technical Background and Assumptions

38.2 Input

38.2.1 Packaged TRU $>100 \mathrm{nCi} / \mathrm{g}$ waste.

38.3 Requirements

38.3.1 Retrievable storage at the INEL.

38.4 Output

38.4.1 Packaged TRU $>100 \mathrm{nCi} / \mathrm{g}$ waste. 
Functional Subelement 39. Reclassified Low-Level Waste Packaging

39.1 Technical Background and Assumptions

39.1 .1 Assume reclassified LLW has same INEL WAC as LLW.

39.2 Inpui

39.2 .1

Reclassified LLW waste in a frit or monolith form with a concentration of $10 \mathrm{nCi} / \mathrm{g}$ $<$ TRU $<100 \mathrm{nCi} / \mathrm{g}$.

39.3 Requirements

39.3 .1

Packaging shall be per INEL LLW Waste Acceptance Criteria (see Reference 6).

39.3 .2 Disposal shall be per INEL LLW disposal criteria (see Reference 6).

39.4 Output

39.4 .1 Packaged $10 \mathrm{nCi} / \mathrm{g}<\mathrm{TRU}<100 \mathrm{nCi} / \mathrm{g}$ waste in an approved container.

Functional Subelement $40 . \quad$ Low-Level Waste Packaging INEL Disposal

40.1 Technical Background and Assumptions

40.1.1 The waste derived from fixing the offgas residue into borosilicate glass is assumed to be LLW. The potential for TRU elements to be carried off into the offgas waste stream is considered to be very small. Classification as LLW is verified in the assay subelement (50.0).

40.2 Input

40.2.1 Low-level waste in a borosilicate glass frit or monolith form.

40.3 Requirements

40.3.1 Packaging shall be per INEL LLW Waste Acceptance Criteria (see Reference 6). 40.4 Output

40.4.1 Packaged LLW. 


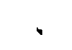

.

$+$ 


\section{Option F \\ Retrieval/Interim Storage/Incineration/Melter Treatment}

Functional Subelement 1. Site/Waste Characterization

1.1 Background Technical Information and Assumptions

1.1.1 The waste pits were excavated to the underlying basalt layer and generally backfilled with 2 to $5 \mathrm{ft}$ of soil to provide a level floor. The waste trenches were gencrally excavated to the basalt layer, approximately $10 \mathrm{ft}$ down and averaged about $7 \mathrm{ft}$ wide and up to $1800 \mathrm{ft}$ long (see Reference 4). Following excavation, wastes were placed into the pits and trenches. From 1952-1963, the waste containers were stacked to optimize disposal space. During 1963-1969, the waste packages were randomly dumped into the pits and trenches in order to limit worker radiation exposure. In 1969, the waste containers were once again stacked to optimize disposal volume. Once emplaced, the wastes were backfilled with and covered with silty clay and sandy soil.

1.1.2 Physical dimensions of each waste pit and trench (including overburden) are given in Tables 1, 2, and 3 of Reference 4. Details of the characteristics of INEL RWMC soils are given in Tables 4 through 8 of Reference 4 (see Appendix A).

1.1.3 Figure 7 illustrates a cross-section of a typical Operable Unit (OU) 7-13 waste pit or trench. The figure identifies terms used throughout this report.

1.2 Input

Transuranic (TRU)-Contaminated Waste Pits and Trenches located at the INEL Subsurlace Disposal Area (designated as Operable Unit 7-13).

\subsection{Requirements}

The following shall be determined during site/waste characterization:

1.3.1 Vertical boundaries of the waste pits and trenches.

1.3.2 Depth of the basalt underlying the waste pits and trenches.

1.3.3 Depth of the overburden/waste interface for each waste pit and trench.

1.3.4 Location of any outsize waste in the waste seam.

\subsection{Output}

Estimated boundaries of TRU-Contaminated Waste Pits and Trenches. 
Functional Subelement $2 . \quad$ Below-Grade Isolation

2.1 Background Technical Information and Assumptions

2.1.1 The basalt is assumed to offer below-grade horizontal isolation of the waste.

2.1.2 The concern of leakage through the barriers is mitigated by INEL RWMC site renovations performed under the 300-yr Flood Drainage Program.

2.1.3 The subsurface basalt is at a depth that is less than $30 \mathrm{ft}$ for any given waste pit or trench.

2.1.4 The defined waste seam will be established by an institutional review of the estimated boundaries (see Figure 8). Establist.ment of the defined waste seam will be performed by institutional entities. This group will be expected to identify the defined waste seam boundary for each pit or trench that includes some margin in addition to the estimated boundary values.

2.2 Input

2.2.1 Estimated boundaries of TRU-Contaminated Waste Pits and Trenches.

\subsection{Requirements}

2.3.1 Construct engineered barriers extending vertically from the surface to the basalt at the location of the defined waste seam to provide below-grade isolation of the volume to be remediated.

2.3.2 The engineered barriers shall be designed to meet or exceed all the applicable federal, state, and DOE structural safety standards for mining or excavations.

2.4 Output

Below-grade isolation barriers which define the volume of waste to be remediated.

Functional Subelement 3. Above-Grade Containment

3.1 Background Technical Information and Assumptions

3.1.1 The entire above-grade containment shall have a facility classification of moderate hazard per UCRL-15910 (see Reference 9).

\subsection{Input}

Below-grade isolation barriers of the volume to be remediated. 


\subsection{Requirements}

3.3.1 The above-grade containment structure(s) must encompass the entire volume currently being excavated.

3.3.2 The above-grade containment structure(s) shall be designed and constructed to meet the following applicable INEL building standards: General Design Critcria (DOE 6430.1A), ${ }^{10}$ Natural Phenomenon (UCRL-15910), ${ }^{9}$ DOE-ID Architcctural Engineering Standards, ${ }^{11}$ Operational Safety Design Criteria Manual, ${ }^{12}$ Industry Standard Uniform Building Code (UBC), and requirements set forth in Nuclear Safety Analysis Reports (DOE Order 5480.23).

3.3.3 The above-grade containment structure(s) shall have the following features:

3.3.3.1 Shall be designed to control contamination from radiological and non-radiological sources to allow maintenance repair or replacement of systems.

3.3.3.2 Shall be designed to allow all necessary activities to support ancillary activities conducted within the containment structure such as retrieval, package, and transport of excavated waste.

3.3.3.3 Shall be designed to allow ingress/egress of all equipment and personnel necessary to perform all waste retrieval activities.

3.3.3.4 Shall be designed to allow the egress of retrieved waste packaged for transport.

3.3.3.5 Shall have temperature and humidity control such that the environment is regulated within the limits required for maintenance repair or replacement activitics in a beta, gamma, alpha, and hazardous contaminated environment.

3.3.4 The above-grade containment structure shall contain all operations from overburden retrieval to transport to interim storage/treatment.

\subsection{Output}

Completed and operational containment facility over the isolated region being excavated.

Functional Subelement $4 . \quad$ Overburden Characterization

\subsection{Background Technical Information and Assumptions}

4.1.1 Prior to any removal of overburden, an extensive characterization of the overburden will be performed.

4.1.2 Data from overburden characterization activities will meet data quality objectives and be useable for risk assessments. 
4.2 Input

4.2.1 Completed and operational containment facility over the isolated region being excavated.

\subsection{Requirements}

The characterization will locate any regions of contamination within the pit or trench overburden.

4.3.2 Characterization techniques must be able to sample for radioactive, including TRU, and characteristic and listed hazardous contaminants defined in the BWID Systems Analysis system requirements (see Reference 1).

\subsection{Output}

4.4.1 Location and characterization of radioactive and characteristic and listed hazardouscontaminated overburden.

Functional Subelement 5. Overburden Removal

\subsection{Technical Background and Assumptions}

\subsection{Input}

Location and characterization of radioactive and characteristic and listed hazardouscontaminated overburden.

\subsection{Requirements}

5.3.1 Up to $75 \%$ of the estimated overburden deptr. for each pit or trench will be removed. Sufficient overburden will be left in place so as to minimize the possibility of an inadvertent contamination exposure.

5.3.2 The removal process wil' separate contaminated (radioactive and hazardous) from noncontaminated overburden.

5.3.3 Overburden removal operations must control contamination from beta, gamma, alpha, and the hazardous constituents defined in the BWID Systems Analysis system requirements (see Reference 1) to levels that would allow maintenance to service or repair equipments.

5.3.4 These systems shall meet or exceed all state, federal, and DOE nuclear systems standards for explosion proof, fire protection, and suppression. 


\subsection{Output}

5.4.1 The completed containment facility over the region to be remediated. Up to $75 \%$ of overburden removed.

5.4.2 Contaminated (radioactive and hazardous) overburden.

5.4.3 Noncontaminated overburden.

Functional Subelement $6 . \quad$ Storage of Contaminated Overburden

6.1 Technical Background and Assumptions

6.2 Input

6.2.1 Contaminated (radioactive and hazardous) overburden.

6.3 Requirements

6.3.1 Contaminated overburden must be stored within the above-grade containment structure(s).

6.3.2 Contaminated overburden must be physically separated from retrieved noncontaminated and nonassayed overburden.

6.3.3 Stored contaminated overburden shall not cause a criticality.

6.3.4 Stored contaminated overburden shall have beta, gamma, alpha, and hazardous contamination control compatible with containment requirements of 3.3.3.1.

\subsection{Output}

6.4.1 Stored contaminated overburden.

Functional Subelement 7. Noncontaminated Overburden Storage

7.1 Technical Background and Assumptinns

7.2 Input

7.2.1 Retrieved noncontaminated overburden.

7.3 Requirements

7.3.1 Retrieved noncontaminated overburden shall be stored in a weather shielded storage. 
If the noncontaminated storage is located outside the containment building then the noncontaminated overburden shall be surveyed to ensure that it is free of beta, gamma, alpha, and hazardous contamination prior to removal from the containment building.

\subsection{Output}

7.4.1

Stored noncontaminated overburden to be used to refill the remediated pit or trench.

\section{Functional Subelement $8 . \quad$ Retrieval}

\subsection{Technical Background and Assumptions}

8.1 .1

The retrieval functional subelement includes all apparatus to remove all remaining overburden and the waste from the ground, control the spread of contamination during the removal, and convey the retrieved waste from the dig face to a packaging area for eventual shipment for treatment.

8.1.2 The assumption for this subelement is that criticality can be prevented.

\subsection{Input}

8.2.1

The completed containment facility over the region to be remediated. $75 \%$ of estimated overburden depth removed.

\subsection{Requirements}

8.3.1 The retrieval system shall exhume material within the waste seam and transfer that material to a waste conveyance system.

8.3.2 The retrieval systems shall operate within the temperature and humidity limits inside the containment structure.

The retrieval systems must be designed to accommodate operations, maintenance, and repair in a beta, gamma, alpha, and hazardous contamination environment.

8.3.4 The retrieval system shall be designed such that a criticality cannot occur.

8.3.5 Retrieval operations must identify and accommodate atypical waste objects (objects or material incompatible with the retrieval system) or high radiation sources. Identification may involve characterization at the dig-face. NOTE: An acceptable way to "accommodate atypical waste" objects is that the retrieval system may move these objects and stabilize them in the retrieval pit or other designated area to prevent contamination spread and/or to shield high sources of radiation as stated in system requirements (see Reference 1). Retrieval operations may bypass these 
stabilized objects and continue normal operations until such time that special case equipments and procedures will allow for their removal.

8.3.6 The retrieval system shall meet or exceed all applicable state, federal, and DOE nuclear systems standards for explosion proof, fire protection, and suppression.

8.3.7 Retrieval operations and waste packaging for conveyance will be designed such that personnel exposure to radiation will comply with DOE Order 5480.11, "Radiation Protection for Occupational Workers."

8.3.8 Retrieval operations and waste packaging for conveyance will be designed such that personnel exposure to hazardous materials will comply with all applicable OSHA standards.

\subsection{Output}

Exhumed waste. Waste characteristics defined in BWID Systems Analysis system requirements (see Reference 1 ).

\section{Functional Subelement $9 . \quad$ Waste Conveyance}

9.1 Technical Background and Assumptions

9.1.1 The conveyance functional subelement includes all apparatus to convey the retrieved waste or removed overburden within the containment structure.

\subsection{Input}

9.2.1 Exhumed waste. Waste characteristics defined in BWID System Analysis system requirements (see Reference 1).

\subsection{Requirements}

9.3.1 The waste conveyance system shall be designed so that a criticality event cannot occur.

9.3.2 The waste conveyance system must be designed to accommodate operations, maintenance, and repair in a beta, gamma, alpha, and hazardous contamination environment.

9.3.3 These systems shall meet or exceed all state, federal, and DOE nuclear systems standards for explosion proof, tire protection, and suppression.

9.3.4 The conveyance system shall operate within the temperature and humidity limits in the containment structure. 
The conveyance system will be designed such that personnel exposure to radiation will comply with DOE Order 5480.11, "Radiation Protection for Occupational Workers."

9.3.6 The conveyance system will be designed such that personnel exposure to hazardous materials will comply with all applicable OSHA standards.

\subsection{Output}

Conveyed, exhumed waste. Waste characteristics defined in system requirements (see Reference 1).

Functional Subelement $10 . \quad$ Size Reduce

10.1 Technical Background and Assumptions

10.1.1 The size reduction subelement will be capable of size reducing all waste in the waste stream. It is assumed the size reduction subelement will result in a waste stream that meets the size reduction input requirements of the downstream treatment processes (incinerator and/or melter).

10.2 Input

10.2.1 Exhumed waste. Specifics on expected waste types and their contaminants can be found in system requirements (see Reference 1).

\subsection{Requirements}

10.3.1 A size reduction shall occur to the extent necessary so that the waste is in a form compatible with the radiological/VOC assay technology.

10.3.2 The size reduction system shall be designed to accept all waste of the composition and size described in system requirements (see Reference 1).

10.3.3 The size reduction system shall be designed so that a criticality event cannot occur.

10.3.4 The size reduction system must be designed to accommodate operations, maintenance, and repair in a beta, gamma, alpha, and hazardous contamination environment.

10.3.5 This equipr. ent shall meet or exceed all State, Federal, and DOE nuclear systems standards for explosion proof, fire protection, and suppression.

10.3.6 The size reduction system shall operate within the temperature and humidity limits in the containment structure. 

Workers."

10.3.8 The packaging system will be designed such that personnel exposure to hazardous materials will comply with all applicable OSHA standards.

10.4 Output

10.4.1

Sized reduced waste conveyed in a form compatible with assay system.

Functional Subelement 11. Radioactive Plus VOC Assay

\subsection{Technical Background and Assumptions}

11.1.1 The basis for the Waste Acceptance Criteria for interim storage will be the INEL TRU WAC (see Reference 7). This is assumed to cover Hazardous, Low Level, Low Level Mixed, and TRU Mixed waste.

11.1.2 All waste arriving at the assay system can be assayed.

\subsection{Input}

11.2.1 Sized reduced waste conveyed in a form compatible with assay system.

11.2.2 Contaminated overburden.

\subsection{Requirements}

11.3.1 The radioactive/VOC assay system shall be designed so that a criticality event cannot occur.

11.3.2 The radioactive/VOC system must be designed to accommodate operations, maintenance, and repair in a beta, gamma, alpha, and hazardous contamination environment.

11.3.3 This equipment shall meet or exceed all State, Federal, and DOE nuclear systems standards for explosion proof, fire protection, and suppression.

11.3.4 The radioactive/VOC assay for criticality, hazardous, and radioactive constituents shall meet requirements of the interim storage Waste Acceptance Criteria (INEL TRU Waste Acceptance Criteria).

11.3.5 The radioactive/VOC assay system shall operate within the temperature and humidity limits in the containment structure. 

to radiation will comply with DOE Order 5480.11, "Radiation Protection for Occupational Workers."

11.3.7 The radioactive/VOC assay system will be designed such that personnel exposure to hazardous materials will comply with all applicable OSHA standards.

11.3.8 The assaying system must be able to measure radioactive constituents, including TRU and organic compounds identified in the BWID System Analysis System Requirements (see Reference 1).

\subsection{Output}

Entire waste stream.

11.4.2 Radiological and VOC assay data for the waste stream.

Functional Subclement 12. $\quad$ Packaging

12.1 Technical Background and Assumptions

12.1.1 All retrieved waste (including hazardous, low-level, and mixed) can be packaged and transported to interim storage.

12.2 Input

12.2.1 Entire waste stream.

12.2.2 Radiological and VOC assay data for the waste stream.

12.3 Requirements

12.3.1 Retrieved and assayed waste stream shall be packayed and labeled to meet all of the RWMC transportation requirements (see References 6 and 7 and footnotc e).

12.3.2 Retrieved and assayed waste stream shall be packaged and labeled to mect INEL Transuranic Waste Acceptance Criteria.

12.3.3 The packaging system shall be designed so that a criticality event cannot occur.

12.3.4 The packaging system must be designed to accommodate operations, maintenance, and repair in a beta, gamma, alpha, and hazardous contamination environment.

12.3.5 Equipment shall meet or exceed all State, Federal, and DOE nuclear systems standards for explosion proof, fire protection, and suppression. 

the containment structure.

12.3.7 The packaging system will be designed such that personnel exposure to radiation will comply with DOE Order 5480.11, "Radiation Protection for Occupational Workers."

12.3.8 The packaging system will be designed such that personnel exposure to hazardous materials will comply with all applicable OSHA standards.

\subsection{Output}

12.4.1

Waste which is in an acceptable form for transportation to interim storage and interim storage.

Functional Subelement 13. Transportation

13.1 Technical Background and Assumptions

13.1.1 Transportation to interim storage can occur within the RWMC and thus will not have to fully comply with EG\&G Hazardous Material Transportation Manual (see footnote $\mathrm{f}$ ).

\subsection{Input}

Waste which is in an acceptable form for transportation to and storage in interim storage.

\subsection{Requirements}

RWMC transportation requirements (see footnote e).

\subsection{Output}

Packaged waste and its associated assay information delivered to interim storage facilities.

\section{Functional Subelement 14. INEL Interim Storage}

14.1 Technical Background and Assumptions

14.1.1 Interim storage facilities will be constructed and operated by INEL waste management operations.

14.1.2 Interim storage facilities will accept ali elements of the waste stream (hazardous, low level, low level mixed, TRU, TRU mixed). 
14.1.3 The interim storage facility will be approved to store RCRA wastes.

14.1.4 The interim storage Waste Acceptance Criteria is assumed to be based upon the INEL TRU WAC (sec Reference 7).

14.2 Input

14.2.1 Packaged waste and its associated assay information delivered to interim storage facilities.

14.3 Requirements

14.3.1 The interim storage facility will be capable of storing the packaged waste until the thermal treatment facility is ready to accept waste.

14.3.2 Waste package assay data will be retained.

14.4 Output

14.4.1 Waste which is in an acceptable form for transportation to treatment and waste assay data.

Functional Subelement 15. Transportation

15.1 Technical Background and Assumptions

15.1.1 The treatment facility is not co-located with interim storages; however, it is located within the INEL.

15.2 Input

15.2.1 Waste which is in an acceptable form for transportation to treatment and waste assay data.

15.3 Requirements

15.3.1 INEL transportation requirements (see footnotes e and f).

15.4 Output

15.4.1 Packaged waste and associated assay information delivered to the pretreatment size reduction subelement. 
Functional Subclement 16. Treatment Facility General Requirements

16.1 Technical Background and Assumptions

16.1.1 The treatment facility has a classification of Moderate Hazard per UCRL-15910 (sec Reference 9).

16.1.2 The entire thermal processing line can be designed, constructed, and tested to maintain alpha contamination controls.

16.1.3 The treatment facility shall meet requirements outlined in Nuclear Safety Analysis Reports (DOE Order 5480.23).

16.2 Input

16.2.1

Not applicable

16.3 Requirements

16.3.1 A minimum of double confinement per DOE Order 6430.1A shall exist between normally contaminated areas and uncontrolled areas.

16.3.2 Equipment designs and interfaces shall be designed to maintain alpira, beta, and gamma contamination confinement.

16.3.3 All systems in the treatment facility shall be designed so that a criticality event cannot occur. The treatment facility will follow criticality control requirements per DOE 5480.5 (see Reference 13) and DOE-ID 5480.5A (see Reference 14).

16.3.4 These systems shall meet or exceed all State, Federal, and DOE nuclear systems standards for explosion proof, fire protection, and suppression.

16.3.5 All systems in the treatment facility will be designed such that personnel exposure to radiation will comply with DOE Order 5480.11, "Radiation Protection for Occupational Workers."

16.3.6 All systems in the treatment facility will be designed such that personncl exposure to hazardous materials will comply with all applicable OSHA standards.

16.3.7 The overall treatment facility and operational systems shall meet the requirements for a Radioactive Solid Waste Facility per DOE Order 6430.1A, Section 1324 (sce Reference 10).

16.3.8 Additional high-level requirements are contained in Reference 15. 
16.4 Output

16.4.1 Not applicable

Functional Subelement $17 . \quad$ Treatment Facility Receiving

17.1 Technical Background and Assumptions

17.1.1 The receiving subelement performs the functions of accepting transported material supplied by the transportation-for-treatment subclement. Temporary storage for queuing may or may not be a required function, and is dependent upon the specitic technologies comprising the technology process options.

17.2 Input

17.2.1 Packaged waste and associated assay information delivered to the treatment facility.

17.3 Requirements

17.3.1 Receive waste from transportation system and store until treatment waste conveyance is ready to accept waste.

17.4 Output

17.4.1 Waste and associated assay information delivered to the treatment waste conveyance system.

Functional Subelement $18 . \quad$ Treatment Waste Conveyance

18.1 Technical Background and Assumptions

18.1.1 The conveyance functional subelement includes all apparatus to convcy the retrieved waste or removed overburden within the treatment containment structure.

18.2 Input

18.2.1 Packaged waste and associated assay information delivered to the treatment waste conveyance.

18.3 Requirements

18.3.1 The waste conveyance system must be designed to accommodate operations, maintenance, and repair in a beta, gamma, alpha, and hazardous contamination environment.

18.3.2 The conveyance system shall operate within the temperature and humidity limits in the containment structure. 
The conveyance subelement must be able to convey all the various forms of wastes within the treatment facility.

The conveyance subelement must convey necessary process leedstocks and process by-products.

Waste conveyance shall not change waste characteristics.

18.4 Output

Packaged containers containing quantities of soil and waste. The waste consists of combustibles and noncombustibles contaminated with organics, radionuclides, and heavy metals. Specifics on expected waste types and their contaminants can be found in the BWID PBTSF Description Report (see Reference 1).

Functional Subelement 19. $\quad$ Size Reduction

19.1 Technical Background and Assumptions

19.1.1 Much effort has been spent on characterization of the RWMC buried waste. Because of less stringent disposal methods, a large degree of inaccuracy must be assumed for any published numbers. The thermal treatment scenarios consider the waste input stream to contain these waste categories plus contaminated soil in varying amounts and percentages.

19.1.2 The size reduction required for processing is less restrictive than for assay monitoring. Thus, assume size reduction performed carlier (subelement 10, Reduce Size) meets size requirements for follow-on processes within the treatment system. Also, assume that interim storage containers will become part of the waste stream, and thus must be size reduced.

19.2 Input

19.2.1

Packaged and intact containers containing previously size-reduced quantities of soil and waste. The waste consists of combustibles and noncombustibles contaminated with organics, radionuclides, and heavy metals. Specifics on expected waste types and their contaminants can be found in the BWID Systems Analysis System Requirements (see Reference 1).

\subsection{Requirements}

19.3.1 Process must be capable of reducing size of containers to meet size requirements of downstream treatment process.

\subsection{Output}

19.4.1

Reduced waste stream. 
Functional Subelement 20. Pre-Treatment Characterization

20.1 Technical Background and Assumptions

20.1.1 It is assumed that the thermal process treatment owner will require independent characterization data for efficient and safe operations.

20.2 Input

20.2.1 Reduced waste strean.

20.3 Requirements

20.3.1 Monitor for gross VOCs identified in BWID Systems Analysis System Requirements (see Reference 1) to assist in melter performance and maintain safe operations.

20.3.2 Monitor for gross radionuclides in BWID Systems Analysis System Requirements (see Reference 1) to assist in process safety controls and quality control of the final waste form.

20.3.3 Monitor as necessary for other gross concentrations of constituents which are difficult to process such as chlorides, HVPMs, and Sulfur. The constituents that are difficult to process are determined by the melting technology chosen.

20.3.4 Data acquisition compatible with down-stream processes.

20.4 Output

20.4.1 Entire waste stream not changed from input.

20.4.2 Data on VOCs, radionuclides, radiation intensity, and other constituents which are difficult to process.

Functional Subelement 21. № Sort

21.1 Technical Background and Assumptions

21.1.1 It is assumed that a minimum amount of soil is a part of the input waste stream for the desired final waste form. This soil comes from TRU and hazardouscontaminated interstitial soil or contaminated underburden soil. The minimum percentage of soil depends on solubility of the aifferent elements which are desired to be bound into the final waste form. The actual minimum percentage number is dependant on specifications for the final form which are not defined (sic) as yet. 
21.2 Input

21.2.1 Reduced waste stream from the pretreatment characterization and size reduction subelements.

\subsection{Requirements}

21.3.1 None.

\subsection{Output}

21.4.1 Size-reduced waste stream.

Functional Subelement 23. Thermal Desorber

23.1 Technical Background and Assumptions

23.1.1 The thermal desorber functional subelement disassociates nitrate compounds that could cause combustible pulsing of the incinerator. The thermal desorber operating temperature is based on a temperature which is high enough for initial thermal decomposition of nitrates (potassium nitrate decomposes at $400^{\circ} \mathrm{C}$, and sodium nitrate decomposes at $380^{\circ} \mathrm{C}$ ).

\subsection{Input}

\subsubsection{Full waste stream.}

23.2.2 Offgas from the High Temperature Oxidizing Slag, Oxidizing Metal/Metal Tapping Melter.

\subsection{Requirements}

23.3.1 Heat all waste stream constituents to a temperature of TBD degrees centigrade.

23.3.2 Hold preheated waste stream constituents at a temperature of TBD degrees for a time of TBD minutes.

23.3.3 Meet input requirements of downstream processes.

23.3.4 Process main waste stream at system throughput rate.

\subsection{Output}

23.4.1 Preheated waste stream.

23.4.2 Offgas. 
Functional Subelement $24 . \quad$ Incinerator

24.1 Technical Background and Assumptions

24.1.1 Incineration/pyrolysis of the waste stream is performed to combust the majority of the combustible portion (including organics) of the waste stream. Low temperature incineration may be preferred for reduction in corrosion and erosion of the incinerator. This also may result in reduction in plugging potential of the ash and residuals in the material handling system.

24.1.2 Note that this option provides for incineration of the full waste stream which consists of combustibles, soil, noncombustibles, and metals. By processing the entire waste stream, it is recognized that the efficiency of incineration may be reduced. However, it may be that the gain realized from maintaining a simplistic design with reduced numbers of subelements outweighs any loss in efficiency. Incinerators can be built very robust and, therefore, the overall thermal process system is not jeopardized by processing noncombustibles and metals in the incinerator. Further, one of the largest driving factors in alpha processing systems is the cost of maintaining alpha controls. To this end, the fewer number of subsystems required, the easier it is to maintain strict alpha controls.

24.1.3 It is also very desirable to adopt a design that will produce a minimum offgas flow rate. This will simplify any necessary offgas treatment system.

24.2 Input

24.2.1 Preheated waste stream.

24.2.2 Offgas from the Thermal Desorber subelement.

24.3 Requirements

24.3.1

Incineration/pyrolysis of the waste stream.

24.3.2

Meet downstream input requirements and system throughput processing rate.

\subsection{Output}

24.4.1

Pyrolized ash.

24.4 .2

A combusted offgas stream plus minor products of incomplete combuscion. 
Functional Subelement $25 . \quad$ Alterburner

25.1 Technical Background and Assumptions

25.1.1 The output stream from the afterburner is assumed to contain $\mathrm{H}_{2} \mathrm{O}, \mathrm{CO}_{2}$, High Vapor Pressure Metals (HVPMs, mercury, lead, cadmium, arsenic, ctc.), HVPM oxides, halogens, sulfur compounds, combusted organics, particulates, and some radionuclides ( $\mathrm{Cs}^{137}$, potential minor quantities of TRU oxides, and other LLW radionuclides).

25.1.2 One possible design will maintain the offgas stream for a minimum time at a minimum temperature (approximately $>2 \mathrm{sec}$ at $>1010^{\circ} \mathrm{C}$ ) to ensure complete combustion.

25.2 Input

25.2.1

A combusted offgas stream plus minor products of incomplete combustion from the incinerator.

25.3 Requirements

25.3.1 The afterburner shall ensure 99.9999 percent (1 part in $10^{6}$ ) combustion of all organics in the offgas stream.

\subsection{Output}

25.4.1 Combusted offgas stream.

Functional Subelement 26. $\quad \underline{\text { Mixer }}$

26.1 Technical Background and Assumptions

26.2 Input

26.2.1 Pyrolized ash from the incincrator.

26.2.2 Flux if required for melter process control.

26.2.3 Basaltic soil as needed for melter process control and final waste form quality control.

26.3 Requirements

26.3.1 Mix and blend feedstock. 
26.4 Output

26.4.1

Blended feedstock to the melter.

Functional Subelement 27. Oxidizing Slag, Oxidizing Metal/Metal Tapping Melter

27.1 Technical Background and Assumptions

27.1.1 The output stream from the melter is assumed to potentially contain $\mathrm{H}_{2} \mathrm{O}, \mathrm{CO}_{2}$, High Vapor Pressure Metals (HVPMs, mercury, lead, cadmium, arsenic, etc.), HVPM oxides, halogens, sulfur compounds, combusted organics, particulates, and some radionuclides ( $\mathrm{Cs}^{137}$, potential minor quantities of TRU oxides, and other LLW radionuclides).

27.1.2 The composition of the mclten slag output stream is assumed to be an iron-enriched basalt matrix with dissoived metal oxides, and TRU plus LLW contaminants. This assumption is based on work as reported in Reterences 16,17, 18, and 19.

27.1.3 The metals contained in the molten metal output stream are assumed to be mainly iron $(\mathrm{Fe})$ with trace other metals included.

27.2 Input

Blended feedstock from the mixer consisting of metals, ash, soil and residuals from the incinerator; flux as required for melter process control; and soil as needed for melter process control and final waste form quality control.

Oxygen gas.

27.3 Requirements

27.3.1 System throughput processing rate.

27.3.2 Operating temperature high enough to melt metals and melt the basaltic soils maintaining an adequate viscosity for the Homogeneous IEB slag Frit/Monolith subelement.

27.3.3 The output from the melter will contain none of the organic hazardous constituents listed in the system requirements (see Reference 1).

27.4 Outf at

27.4.1 An offgas waste stream to the thermal desorber/incinerator or afterburner.

27.4.2 Molten slag to the slag handling subsystem.

27.4.3 Tapped molten metals to the tapped metal subelement. 
Functional Subelement 28. . $\quad$ Homogeneous Slag Frit/Monolith

28.1 Technical Background and Assumptions

28.1.1 The composition of the molten slag output stream is assumed to be an iron-enriched basalt matrix with dissolved metal oxides, and TRU plus LLW contaminants. This assumption is based on experimental and calculated work as reported in References $16,17,18$, and 19 .

28.1.2 The output of the melter is assumed to be slag frit or monolith, whichever form enables a high quality, high reliability radioactive assay.

\subsection{Input}

28.2.1

Tapped molten slag from the melter.

28.3 Requirements

28.3.1

Receive and handle the molten slag from the melter, and cast it into monoliths or process into a frit form.

28.3.2

The waste form matrix will prevent the release of radionuclides and heavy metals.

\subsection{Output}

28.4 .1

Slag in the form of a frit or monolith compatible with downstream processes.

Functional Subelement 29. Tapped Metal

29.1 Technical Background and Assumptions

29.1.1 No radionuclides, or only very minor quantities of radionuclides are expected to be partitioned into the molten metals stream. The radionuclides are expected to be partitioned into the slag, with potentially some carryover into the offgas system. However, radiological controls must still be emplaced on the metals stream.

29.1.2

The metals contained in the molten metal output stream are assumed to be mainly iron $(\mathrm{Fe})$ with trace other metals included.

29.1.3 A high reliability assay of the metals is assumed to be possible in the monolith form.

29.2 Input

Molten metal tapped from the melter. 
29.3 Requirements

29.3.1

Receive and handle the molten metal from the melter and cast into monolith forms.

29.3.2 Produce a waste form that is no longer considered a nazardous waste per 40CFR261.

\subsection{Output}

29.4.1

A metal monolith waste form.

Functional Subelement 30. $\quad$ Offgas Treatment

30.1 Technical Background and Assumptions

30.1.1 The offgas stream to the offgas treatment system is assumed to contain $\mathrm{H}_{2} \mathrm{O}, \mathrm{CO}_{2}$. High Vapor Pressure Metals (HVPMs, mercury, lcad, cadmium, arsenic, etc.). HVPM oxides, halogens, sulfur compounds, combusted organics, particulates, and some radionuclides $\left(\mathrm{Cs}^{137}\right.$, potential minor quantitics of TRU oxides, and other LLW radionuclic'es).

30.1.2 The offgas unabated release calculations are assumed to confirm the potential for discharge of radionuclides resulting in effective dose equivalents greater than allowable per 40CFR61.92.

\subsection{Input}

30.2.1 Offgas stream from the thermal treatment processes.

30.3 Requirements

30.3.1 The offgas treatment system shall clean the offgas stream of all constituents to allow operations within applicable State and Federal air permit requirements.

30.3.2 Per DOE Order 6430.1A, 40CFR60, 40CFR61, and ANSI N13.1, the offgas treatment system shall be equipped with air monitoring instruments 10 detect radionuclides and hazardous constituents listed in the System Requirements (see Reference 1). The final released offgas eflluent shall be monitored for any normally or accidentally released radionuclides via an isokinetic sampling system.

30.3.3 The offgas systen. must be maintained at a sufficient negative pressure to draw all gascous flows through the systems and still maintain adequate negative pressure at the most remote location. 
30.4 Output

30.4.1 A cleaned offgas gaseous waste stream which meets all appropriate permit requirements.

30.4.2 One or more offgas residue streams.

30.4.3 Process waste stream specific to the offgas treatment chosen.

Functional Subelement 30A. Zero Emissions Offgas Treatment

(Optional)

30A.1 Technical Background and Assumptions

30A.1.1 The offgas stream to the offgas treatment system is assumed to contain $\mathrm{H}_{2} \mathrm{O}, \mathrm{CO}_{2}$, High Vapor Pressure Metals (HVPMs, mercury, lead, cadmium, arsenic, etc.), HVPM oxides, halogens, sulfur compounds, combusted organics, particulates, and some radionuclides $\left(\mathrm{Cs}^{137}\right.$, potential minor quantities of TRU oxides, and other LLW radionuclides).

30A.1.2 Requirements for this type of offgas system are considered to exceed the requirements necessary to meet present day permitting applications. However, permitting actions are assumed to be greatly enhanced with the stricter requirements due to the decreased nature of offgas emissions.

30A.1.3 Zero emissions offgas systems of this type are assumed to be only in the research and development stage. Proven technology is assumed to be non-existent. A large development effort is assumed to be required for this option.

30A.2 Input

30A.2.2 Offgas stream from the thermal treatment processes.

30A.3 Requirements

30A.3.1 The zero emissions oflgas treatment system option shall clean the offgas stream of all constituents with the exception of a minor stream of inert gas. NOTE: These restrictions surpass the present permit requirements for operations. Any minor remaining offgas stream must include tull high efficiency particulate air (HEPA) filtering of the stream.

30A.3.2 This option for offgas treatment must convert all offgas constituents to solid or liquid form for further disposition. 
30A.4 Output

30A.4.1 Potential offgas stream consisting of inert gas.

30A.4.2 An offgas residue stream in liquid or solid form.

Functional Subelement 31.

31.1 Technical Background and Assumptions

31.2 Input

31.2.1 Residue from the offgas treatment subsystem.

31.2.2 Borosilicate glass (BSG) frit.

31.3 Requiremen:s

31.3.1 Mixes and blends leedstock to meet melter input requirements.

31.4 Output

31.4.1 Blended BSG and residue feedstock to the melter.

Functional Subelement 32. Offgas Residue Melter

32.1 Technical Background and Assumptions

32.1.1 Assumed melter temperature is a nominal $1100^{\circ} \mathrm{C}$ based on operating temperatures for melters designed for vitrification of high-level waste (HLW) using borosilicate glass.

32.2 Input

32.2.1 Blended feedstock from the mixer subelement consisting of residuc from the oflgas system and BSG frit.

32.3 Requirements

32.3.1 Operating temperature high enough to melt the BSG frit and the residue, yet low enough to hold the contaminants (high vapor pressure metals, metal oxides, radionuclides, etc.) in solution.

32.3.2 Output must be compatible with downstream processes.

32.3.3 Produce a waste form that is no longer considered a hazardous waste per 40CFR261. 
32.4 Output

Molten slag.

32.4 .2 Offgas effluent.

Functional Subelement 33. Offgas Frit/Monolith

33.1 Technical Background and Assumptions

33.1 .1

The composition of the molten slag output stream is assumed to be a borosilicate glass (BSG) matrix with dissolved metal oxides, and potentially very minor quantities of TRU plus LLW contaminants.

\subsection{Input}

33.2 .1

Molten slag from the offgas residue melter subelement.

33.3 Requirements

33.3.1 Receive and handle the molten slag from the melter, and cast it into monoliths or process into a frit form.

33.3.2 Output is compatible with downstream processes.

\subsection{Output}

33.4 .1

Homogeneous BSG slag in the form of a frit or monolith.

Functional Subelement 34. $\quad$ Post-Treatment Radioactive Assay

34.1 Technical Background and Assumptions

34.1.1 Assume that pretreatment characterization will not satisfy the requirements for classifying output waste form.

34.1 .2

An advantage for thermally processing this type of waste is to convert the asreceived waste stream into a form which will enhance the ability to obtain TRU concentration data with reduced uncertainty.

34.1.3 The bases for this reduction in uncertainty of assay data are:

- The geometry of the assay form can be optimized for the assay equipment (geometry of choice enables consistent geometrical calibration factors).

- Vitrification and homogenization eliminate density variances. 
- Vitrification and homogenization eliminate radionuclide distribution variances (fully dissolved radionuclides and complete mixing).

- Vitrification and homogenization enhance the predictability of self shielding (alpha) unknowns.

- Vitrification and geometry of choice allow for reduced assay time due to assay of a known form with decreased variances and enables assay data to be collected at a waste throughput rate of tons per day.

- Vitrification and enhanced assay capability allow for post-treatment sort of TRU waste and LLW based on reliable and consistent assay data.

- Vitrification and enhanced assay capability increase the ability to identify radionuclides and to quantify concentrations of the radionuclides. This enhanced capability increases the credibility of the data and allows for further rational disposition decisions.

34.2 Input

34.2 .1

Homogeneous IEB or BSG frit or monolith from the thermal treatment subsystems (BSG from offgas stream or IEB from the waste stream).

34.3 Requirements

34.3.1 Identify and quantify radionuclides found in Table 2 of Reference 1 to meet the assay requirements necessary to assign waste as LLW, reclassified LLW, or transuranic as follows:

- $\quad$ TRU $>100 \mathrm{nCi} / \mathrm{g}$ - Transuranic Waste

- $10 \mathrm{nCi} / \mathrm{g}<\mathrm{TRU}<100 \mathrm{nCi} / \mathrm{g}-$ Reclassified LLW

- $\quad$ TRU $<10 \mathrm{nCi} / \mathrm{g}-\mathrm{LLW}$

34.4 Output

34.4.1 Radioactive assay data.

34.4.2 An unchanged frit or monolith waste form.

Functional Subelement 35. Post-Treatment Medium Temperature Fusing/Re-melt

35.1 Technical Background and Assumptions

35.1.1 This subsystem may be unnecessary if a monolith is cast during initial thermal treatment. The output of frit or monolith from the primary thermal treatment subsystem is dependant on the physical form required to enhance the assay capabilities and produce lower uncertainty reliability assay data. 
35.2 Input

35.2.1 Frit or monolith waste from the assay subsystem with TRU $>100) \mathrm{nCi} / \mathrm{g}$.

35.3 Requirements

35.3.1 Fuse or re-melt the IEB frit and cast it into a monolith. (Medium temperature melter operating at a nominal $1400^{\circ} \mathrm{C}$.)

\subsection{Output}

35.4 .1

A monolithic IEB waste form.

Functional Subclement 36. $\quad$ Heat Treat/Controlled Cool

36.1 Technical Background and Assumptions

36.1.1 The purpose of this functional subelement is to change the microstructure of the cast monolith waste form such that the resulting waste form has low leach rate and high durability.

36.1.2 This subelement along with the fusing/re-melt subelement may be unnecessary functions if assay systems are identified that can provide high quality, reliable data from a monolith cast block direct from the primary thermal process subelement.

\subsection{Input}

36.2.1 The input for this subelement is a monolith waste form either direct from the primary thermal process subsystem via the assay subsystem or from the fusing/re-melt melter subelement.

\subsection{Requirements}

36.3.1 Control cooling to optimize the microstructure in order to meet leach rate and durability requirements.

36.3.2 The subsystem shall include nondestructive test capabilities to verify the integrity of the final waste form.

\subsection{Output}

36.4.1

Iron-enriched basalt (IEB) monolith waste form. 
Functional Subelement 37. TRU Waste Packaging

37.1 Technical Background and Assumptions

37.1.1 The designated disposition is for interim storage at the INEL pending resolution and opening of a permanent repository for TRU/TRU-Mixed buried waste.

37.2 Input

37.2.1

Monolithic waste forms with concentration of TRU $>100 \mathrm{nCi} / \mathrm{g}$.

37.3 Requirements

37.3.1 Packaging requirements shall meet current INEL TRU Waste Acceptance Criteria (see Reference 7).

37.4 Output

Packaged TRU > $100 \mathrm{nCi} / \mathrm{g}$ waste.

Functional Subelement 38. Final Package Assay

38.1 Technical Background and Assumptions

38.2 Input

38.2 .1

Packaged TRU > 100 nCi/g waste.

38.3 Requirements

38.3.1

Final assay and external contamination swipe surveys for INEL TRU Waste Acceptance Criteria.

38.4 Output

38.4 .1

Packaged TRU > 100) nCi/g waste.

Functional Subelement 39. INEL TRU Interim Storage

39.1 Technical Backgrnund and Assumptions

39.2 Input

39.2.1 Packaged TRU $>100 \mathrm{nCi} / \mathrm{g}$ waste. 
39.3 Requirements

39.3.1 Retrievable storage at the INEL.

39.4 Output

39.4.1 Packaged TRU $>100 \mathrm{nCi} / \mathrm{g}$ waste.

Functional Subelement 40. Reclassified Low-Level Waste Packaging

40.1 Technical Background and Assumptions

40.1.1 Assume reclassified LLW has same INEL WAC as LLW.

40.2 Input

40.2.1 Reclassitied LLW waste in a frit or monolith form with a concentration of $10 \mathrm{nCi} / \mathrm{g}<\mathrm{TRU}<100 \mathrm{nCi} / \mathrm{g}$.

40.3 Requirements

40.3.1 Packaging shall be per INEL LLW Waste Acceptance Criteria (see Reference 6).

40.3.2 Disposal shall be per INEL LLW disposal criteria (see Reference 6).

40.4 Output

40.4.1 Packaged $10 \mathrm{nCi} / \mathrm{g}<\mathrm{TRU}<100 \mathrm{nCi} / \mathrm{g}$ waste in an approved container.

Functional Subelement 41. Low-Level Waste Packaging INEL Disposal

41.1 Technical Background and Assumptions

41.1.1 The waste derived from tixing the offgas residue into borosilicate glass is assumed to be LLW. The potential for TRU elements to be carried off into the offgas waste stream is considered to be very small. Classification as LLW is verified in the assay subelement (50.0).

41.2 Input

41.2.1 Low-level waste in a borosilicate glass frit or monolith form.

41.3 Requirements

41.3.1 Packaging shall be per INEL LLW Waste Acceptance Criteria (see Reference 6). 
41.4 Output

41.4.1

Packaged LLW. 


\section{REFERENCES}

1. M. C. O'Brien, Performance-Based Technology Selection Description Report, EGG-WTD-9989, May 1992.

2. Federal Facility Agreement and Consent Order, ADN: 1088-06-29-120, Idaho National Engineering Laboratory, May 1991.

3. K. M. Kostelnik, Buried Waste Integrated Demonstration Plan, EGG-WTD-9870, December 1991.

4. D. A. Arrenholz and J. L. Knight, A Brief Analysis and Description of Transuranic Wastes in the Subsurface Disposal Area of the Radioactive Waste Management Complex at INEL, EGGWTD-9438, Rev. 1, August 1991.

5. D. A. Arrenholz and J. L. Knight, Historical Report of Transuranic Waste Pits and Trenches at the Subsurface Disposal Area of the Radioactive Waste Management Complex at the INEL, WTD-91-027. August 1991.

6. U.S. Department of Energy Idaho Field Office (DOE-ID), INEL LCw-r are: Radioactive Waste Acceptance Criteria, DOE/ID-10112, Rev 4., October 1991.

7. U.S. Department of Energy Idaho Field Office (DOE-ID), INEL Transuranic Waste Acceptance Criteria, DOE/ID-10074, Rev., 1991.

8. J. L. Mayberry, W. J. Quapp, F. Feizollahi, and J. C. Del Signore, Preliminary Systems Design Study Assessment Report, EGG-WTD-9594, Vol. II, July 1991.

9. University of California Research Laboratory, Design and Evaluation Guidelines for Department of Energy Facilities Subjected to Natural Phenomenon Hazard, Interim Report, UCRL-15910, October 1989.

10. U.S. Department of Energy, General Design Criteria, DOE Order 6430.1A, April 1989.

11. U.S. Department of Energy Idaho Field Office, DOE-ID Architectural Engineering Standards, September 1991.

12. U.S. Department of Energy Idaho Field Office, Operational Safety Design Criteria Manual, ID-12044, April 1985.

13. U.S. Department of Energy, Safety of Nuclear Facilities, DOE 5480.5, October 1990.

14. U.S. Department of Energy Idaho Field Office (DOE-ID), Safety of Nuclear Facilities, DOE 5480.5A, October 1990. 
15. B. D. Raivo, Functional and Operational Requirements for Waste Technology Division Thermal Processing Technologies-Pilot Test Demonstration (Draft), EGG F/OR 157. Project No. 015525. September 26, 1991.

16. G. A. Reimann, T. L. Grandy, T. L. Eddy, and G. L. Anderson, Summary of INEL Research on the IEB Waste Form (Draft), EGG-WTD-10056, September 1991.

17. A. D. Donaldson, R. J. Carpenedo, and G. L. Anderson, Melter Development Needs Assessment, EGG-WTD-9911, January 1992.

18. P. C. Kong, T. L. Eddy, B. D. Raivo, and G. L. Anderson, Mixed Waste Materials Processing via Thermal Processing Technologies (Draft), EGG-WTD-10058, September 1991.

19. B. A. Detering and J. A. Batdorf, Plasma Treatment of INEL Soil Contaminated With Heavy Metals, EGG-WTD-9925, January 1992. 


\section{Appendix A}

\section{INEL OU 7-13 Waste Pit and Trench Characteristics Tables}


A-2 


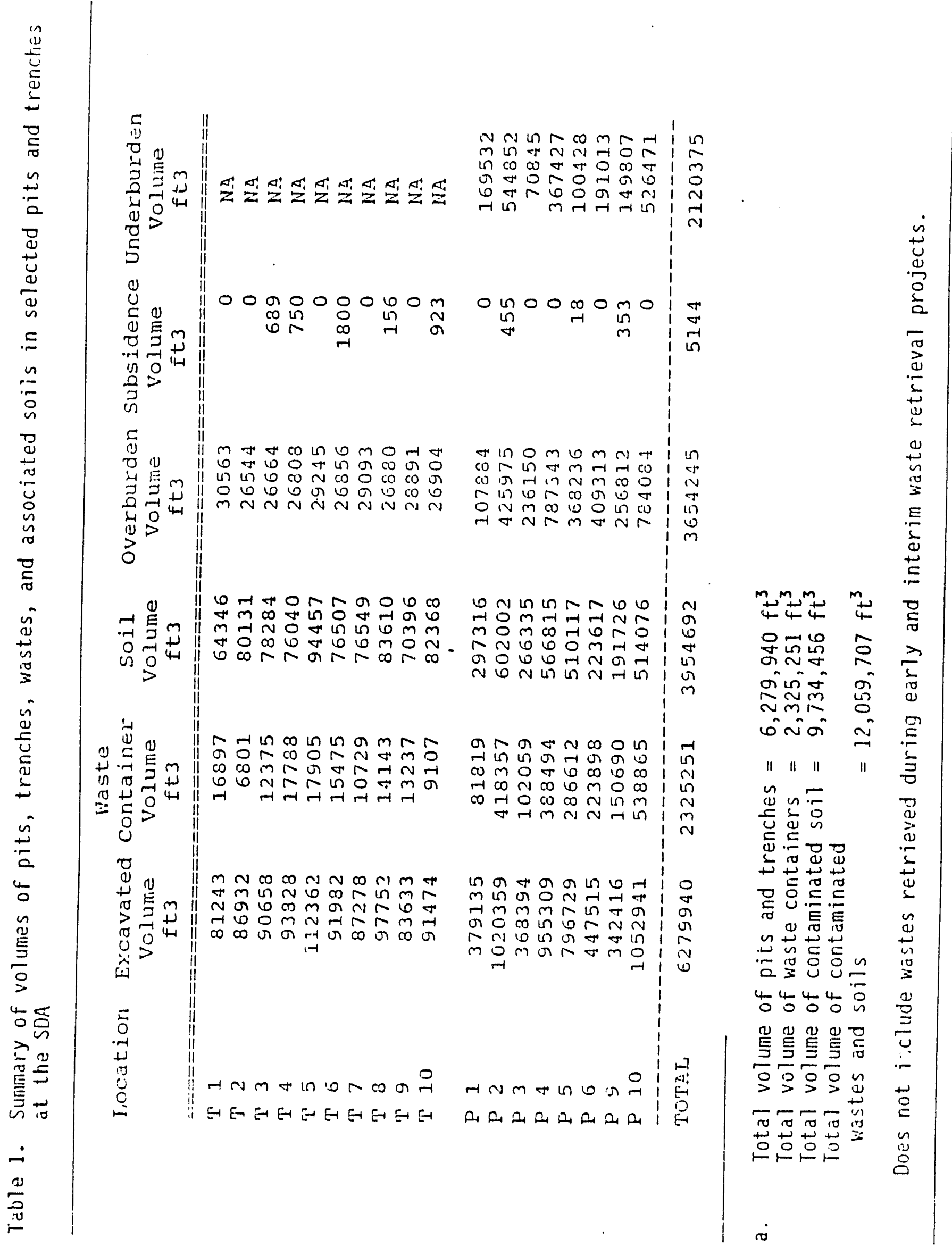




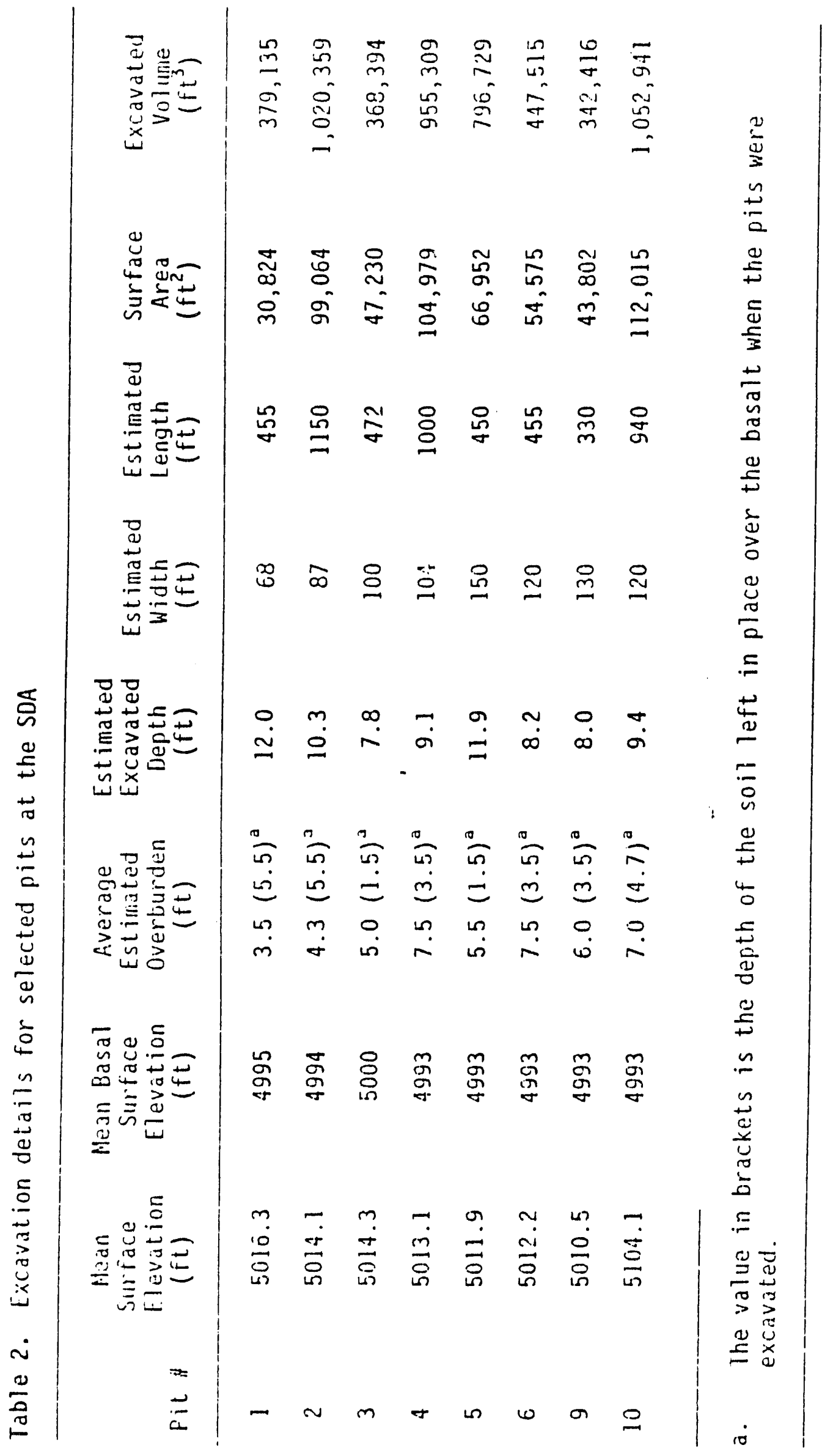




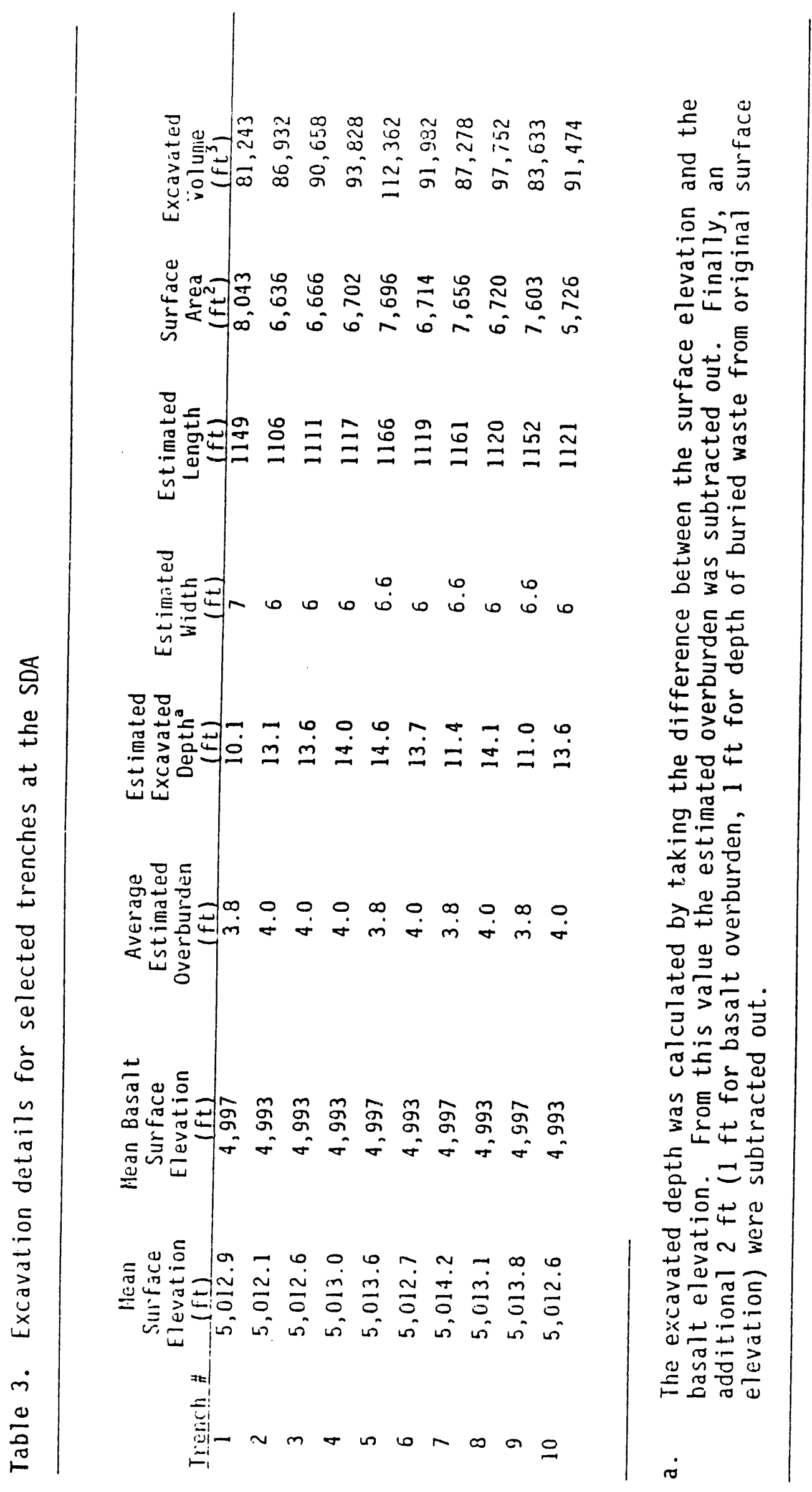


Table 4. Various Physical Characteristics of Soil arid Sediment Samples from the Rivic Wells

\begin{tabular}{|c|c|c|c|c|c|c|c|c|c|}
\hline $\begin{array}{l}\text { We } 11 \\
\text { No. }\end{array}$ & 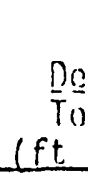 & $\begin{array}{l}10 t h \\
\text { in.) }\end{array}$ & $\begin{array}{l}\frac{1 \text { Inter }}{B o t} \\
\text { Lft }\end{array}$ & $\begin{array}{l}\frac{\text { val }}{\text { toin }} \\
\text { in.) }\end{array}$ & $\begin{array}{r}\text { Specific } \\
\text { Cravity }\end{array}$ & $\begin{array}{c}\text { Bulk } \\
\text { Densit:y } \\
\left(g / \mathrm{cm}^{3}\right)^{2}\end{array}$ & $\begin{array}{l}\text { Porosity } \\
\text { (nercent) }\end{array}$ & $\begin{array}{l}\text { Hoisture } \\
\text { Content } \\
\text { (nercent) }\end{array}$ & $\begin{array}{c}\text { Vertical } \\
\text { Ifydraul ic } \\
\text { Conduct } \\
\text { (in/day) } \\
\end{array}$ \\
\hline 92 & 2 & 6 & 5 & & 2.65 & 1.87 & 34.3 & 12.9 & $5.5 \times 10^{-4}$ \\
\hline 94 & 6 & 6 & 8 & 3 & 2.67 & 2.02 & 30.5 & 16.4 & $2.7 \times 10^{.4}$ \\
\hline 95 & 10 & & 12 & 6 & 2.66 & 1.70 & 41.0 & 13.2 & $7.9 \times 10^{-3}$ \\
\hline
\end{tabular}

Table 5. Properties of soil and sediment samples from the RIMC Wells

\begin{tabular}{|c|c|c|c|c|c|c|c|c|c|c|c|}
\hline \multirow[b]{2}{*}{$\begin{array}{l}\text { Weil } \\
\text { Ho. }\end{array}$} & \multicolumn{4}{|c|}{ Dentin [nterva] } & \multicolumn{3}{|c|}{$\begin{array}{l}\text { Particle Size } \\
\text { Distribidtion }(.,)^{a}\end{array}$} & \multicolumn{3}{|c|}{ Clay Minerals (\%) Mnisture } & \multirow{2}{*}{$\begin{array}{c}\text { Cation Exchange } \\
\text { Capacity } \\
\text { (ineg/100y) }\end{array}$} \\
\hline & $\begin{array}{l}\text { Top } \\
(\mathrm{ft}\end{array}$ & in) & $\begin{array}{l}\text { iott } \\
\text { litt }\end{array}$ & in) & $\frac{\text { Distr }}{\text { Clay }}$ & $\frac{\text { ittion }}{\text { siit }}$ & $\frac{L^{a}}{\text { Sand }}$ & $\begin{array}{c}\text { Kuolin- } \\
\text { ite }\end{array}$ & llite & $\begin{array}{l}\text { Montmor- } \\
\text { illonite }\end{array}$ & \\
\hline$\overline{92}$ & 2 & $\overline{0}$ & 5 & & 21.2 & 48.8 & 30.1 & 2 & 5 & 5 & T4 \\
\hline gd & 6 & 6 & B & 3 & 38.1 & 56.5 & 4.8 & 3 & 9 & 4 & 23 \\
\hline 95 & 10 & & 12 & $\hat{0}$ & 38.5 & 55.6 & 5.9 & 1 & 4 & 3 & 17 \\
\hline Median & & & & & 35.9 & 56.0 & $i .3$ & 2 & 7 & 6 & 21 \\
\hline
\end{tabular}

a. Clay $<0.004 \mathrm{~mm}$
Silt $0.004-0.052 \mathrm{~mm}$
Sand $0.062-<2.00 \mathrm{~mm}$.
b. Hedian of eight sumples. 
Table 6. Particle size distribution for subpit samples (in percent of analyzed sample $e^{a}$ )

\begin{tabular}{|c|c|c|c|c|c|c|c|}
\hline $\begin{array}{l}\text { Sample } 7 \mathrm{e}^{6} \\
\text { Number }\end{array}$ & $\begin{array}{c}\text { Deplh } \\
\text { (in meters) }\end{array}$ & $\begin{array}{c}C 7 a y \\
<0.004 \\
\text { IIIIII }\end{array}$ & $\begin{array}{l}\text { Silt } \\
0.004- \\
0.0625 \\
\quad 11111\end{array}$ & $\begin{array}{l}\text { Sand } \\
\text { Very } \\
\text { Fine } \\
0.0625- \\
0.125\end{array}$ & $\begin{array}{l}\text { Sand } \\
\text { Fine } \\
0.125- \\
0.25 \text { 11min }\end{array}$ & $\begin{array}{l}\text { Sand } \\
\text { Medium } \\
0.25- \\
0.5 \text { IIIII }\end{array}$ & $\begin{array}{c}\text { Sand } \\
\text { Coarse } \\
0.5-1 \text { lillll }\end{array}$ \\
\hline$E W R-1-4$ & 0.91 & 53.3 & 38.5 & 4.8 & 2.3 & 0.9 & 0.1 \\
\hline EWR-1-3 & 1.22 & 41.0 & 30.1 & 11.0 & 17.7 & 0.2 & 0 \\
\hline EWR $-1-2$ & $\therefore .52$ & 54.7 & 40.1 & 4.1 & 0.7 & 0.2 & 0.1 \\
\hline EWR-1-1 & 1.83 & 23.5 & 69.8 & 6.0 & 0.6 & 0 & 0.1 \\
\hline a. & \multicolumn{7}{|c|}{$\begin{array}{l}\text { Analyzed by the USGS Hydrologic Laboratory, Denver, Colorado. } \\
\text { All samples from surficial deposits. }\end{array}$} \\
\hline c. & \multicolumn{7}{|c|}{ No particles coarser than $1 \mathrm{~mm}$ observed. } \\
\hline
\end{tabular}

Table 7. Mineralogy for subpit samples (in percent of analyzed sample) ${ }^{a}$

Sample Deplh Polassium Pryoxene Clay Tolal Number (in melers) Quarla Feldspar Playiuclase Calcile Diuxide Minerats Percenl

\begin{tabular}{|c|c|c|c|c|c|c|c|c|}
\hline [WIR-1-4 & 0.01 & 27 & $\leq 5$ & 11 & 1 & 4 & 70 & $113 t^{6}$ \\
\hline EWIR-1-3 & 1.22 & 29 & $\leq 0$ & 10 & 0 & 9 & 55 & $103+$ \\
\hline [WR-1-2 & 1.52 & 15 & $\leq 3$ & 0 & 41 & $\leq 9$ & 25 & $87+$ \\
\hline LWR-1-1 & 1.83 & 29 & 5 & 12 & 13 & $\leq 9$ & 40 & $29+$ \\
\hline
\end{tabular}
a. Analyzed by the USGS Hydrologic Laboratory, Denver, Colorado.
b. All samples from surficial deposits.
c. Due to high percentage of clay ininerals. 
Table 8. Clay mineralogy of selected surficial sediment samples (in percent of lotal clay minerals/percent of original bulk samples)

\begin{tabular}{|c|c|c|c|c|c|c|c|c|}
\hline Sample & $\begin{array}{l}\text { Depth } \\
\text { (in meters) }\end{array}$ & Chlorite & Illite & $\begin{array}{c}\text { Mixed Layer } \\
\text { Clays } \\
\text { (IIlite/ } \\
\text { Smectite) }\end{array}$ & Sinectite & Kaolinile & $\begin{array}{l}\text { Cation } \\
\text { Exchange } \\
\text { Capacity }\end{array}$ & $\begin{array}{l}\text { Carbonate } \\
\text { Content } \\
\left.\text { (CaCo })_{3}\right) \\
\text { Percent }\end{array}$ \\
\hline EWR-1-4 & 0.91 & $0 / 03$ & $8 / 25$ & $45 / 32$ & $13 / 9$ & $6 / 4$ & 27 & 0 \\
\hline EWli-1-3 & 1.22 & $0 / 03$ & $0 / 10$ & $43 / 20$ & $15 / 9$ & $6 / 3$ & 27 & 2.3 \\
\hline EWR-1-2 & 1.52 & $0 / 03$ & $6 / 9$ & $31 / 8$ & $24 / 6$ & $9 / 2$ & 11 & 36.1 \\
\hline ENR-1-1 & 1.83 & $0 / 03$ & $2 / 12$ & $30 / 12$ & $26 / 10$ & $12 / 5$ & 11 & 10.8 \\
\hline $\begin{array}{l}\text { a. } \\
\text { b. }\end{array}$ & \multicolumn{8}{|c|}{$\begin{array}{l}\text { Analyzed by the USGS Hydrologic Laboratory, Denver, Colorado. } \\
\text { In milliequivalents per } 100 \mathrm{~g} \text {. }\end{array}$} \\
\hline
\end{tabular}



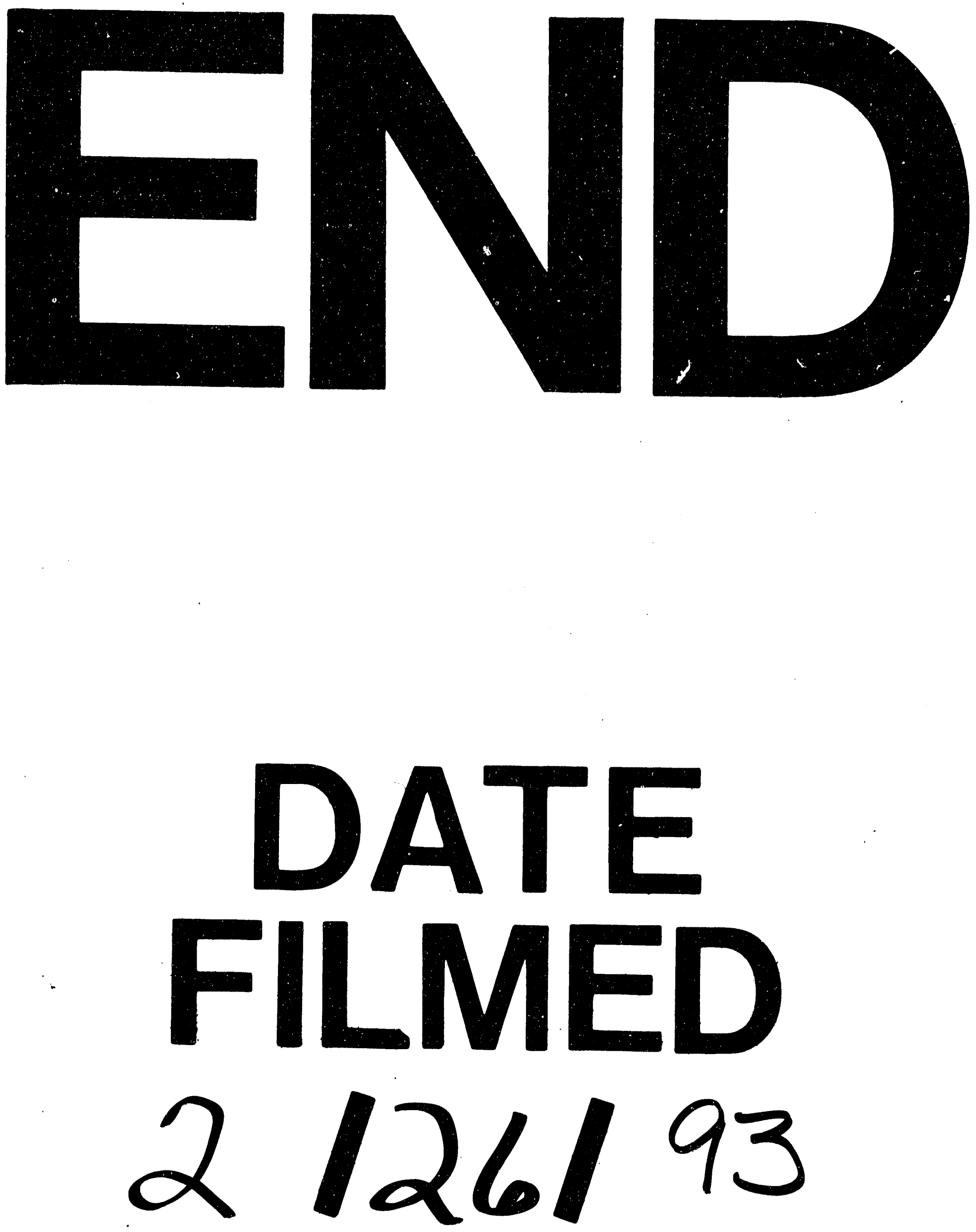
